\title{
Distributional Patterns and Seasonal Movements of Procellariiformes in the North Pacific
}

\author{
Nagahisa Kuroda*
}

\begin{abstract}
Pelagic seabird surveys were made during 11 trans-pacific round navigations of car-transport ships between Japan and U.S.A., March 1983-February 1985. In a total of 124 recorded seabird species (5 Orders, 14 Families), the Procellariiformes included: Diomedeidae 2, Procellariidae 29 and Hydrobatidae 10 species. Their distribution showed the following patterns: 1. Boreal to temperate dispersal pattern 2. Temperate to subtropical dispersal pattern 3. Coastal patterns (Japanese and U.S. west coasts) 4. Subtropical endemic pattern 5. Subtropical to northward dispersal pattern. These distributional patterns reflected the specific adaptive levels to water temperature. The seasonal advance and retreat of migratory front could be traced in some trans-equatorial southern hemisphere species, and the main migratory lane was suggested in the Hawaiian leeward waters. In a few related species pairs, mutual shifts of main distributional sea areas were noticed.
\end{abstract}

\section{Introduction}

General pelagic distribution of seabirds in the North Pacific can be referred to Shuntov (1961, 1968, 1972) and Harrison (1983), and several well planned original surveys of seabirds have been made (see Kuroda 1988). However, they were restricted to local sea areas and by season. For the first time, during 1983-85, an all-season, whole area pelagic survey of North Pacific seabirds was conducted by Seabird Study Group (14 members), temporarily organized for the project and with special emphasis on Puffinus tenuirostris (Oka 1986).

For this survey, Japanese car-transport ships which regularly make monthly round navigations from Japan to U.S. west coast, were used with navigation routes either of northern, middle or southern (via Hawaii) course, thus covering ocean wide sea areas.

The general results are now being prepared for publication by co-authorship of members. In the present paper, distributional patterns of 41 Procellariiform species are analysed and classified, with records on water temperatures preferred by species (Appendix III). This is the second specific report extracted from the general data (see Kuroda 1988).

\section{Study Areas and Method}

During March 1983-February 1985, the North Pacific between Japan and U.S. west coast was crossed by 11 round navigations on board the car-transport ships. The surveyed sea areas covered north from Bering Sea along the Aleutians (the 'northern or subarctic (cold current) route'), south to the navigation course from western Honshu, Japan, via

\footnotetext{
Received 9 April 1991. Accepted 8 May 1991.

* Yamashina Institute for Ornithology. Konoyama, Abiko City, Chiba, Japan. 270-11.
} 
Hawaii, to Long Beach, San Francisco (the 'southern or subtropical (warm current) route'). The 'middle route' in temperate zone (convergent belt), was also taken mainly in spring navigations.

In each navigation, two observers of our study group stood for seabird watch, dawn to sunset, sited in or outside the commanding bridge. ' 30 minutes census sheets' were used, and data of date, time, weather, air temperature, wind and wave directions and class, and the surface water temperature at noon position were recorded. Species and number of seabirds were recorded as they occurred. The sight range was classified: within $100 \mathrm{~m}$, $100-200 \mathrm{~m}, 200-300 \mathrm{~m}$ and more than $300 \mathrm{~m}$. Date, totalized for each day, were treated by computer to be used for various analyses.

The surveyed North Pacific was meshed by 5 degrees longitudes and latitudes and each mesh was coded by combinations of longitudinal numbers and latitudinal alphabets, such as 1a, $2 \mathrm{~b}$ (see Kuroda 1988). The navigation routes were shown by connecting noon positions (Fig. 1).

All months, except July and December, were covered, but navigation frequency was different by season and sea area, March, for example, being represented only by one middle course navigation. Although with this irregularity, some seasonal movements of migration front could be traced, and distributional patterns with seasonal concentrations were specifically shown on the meshed maps of the North Pacific.

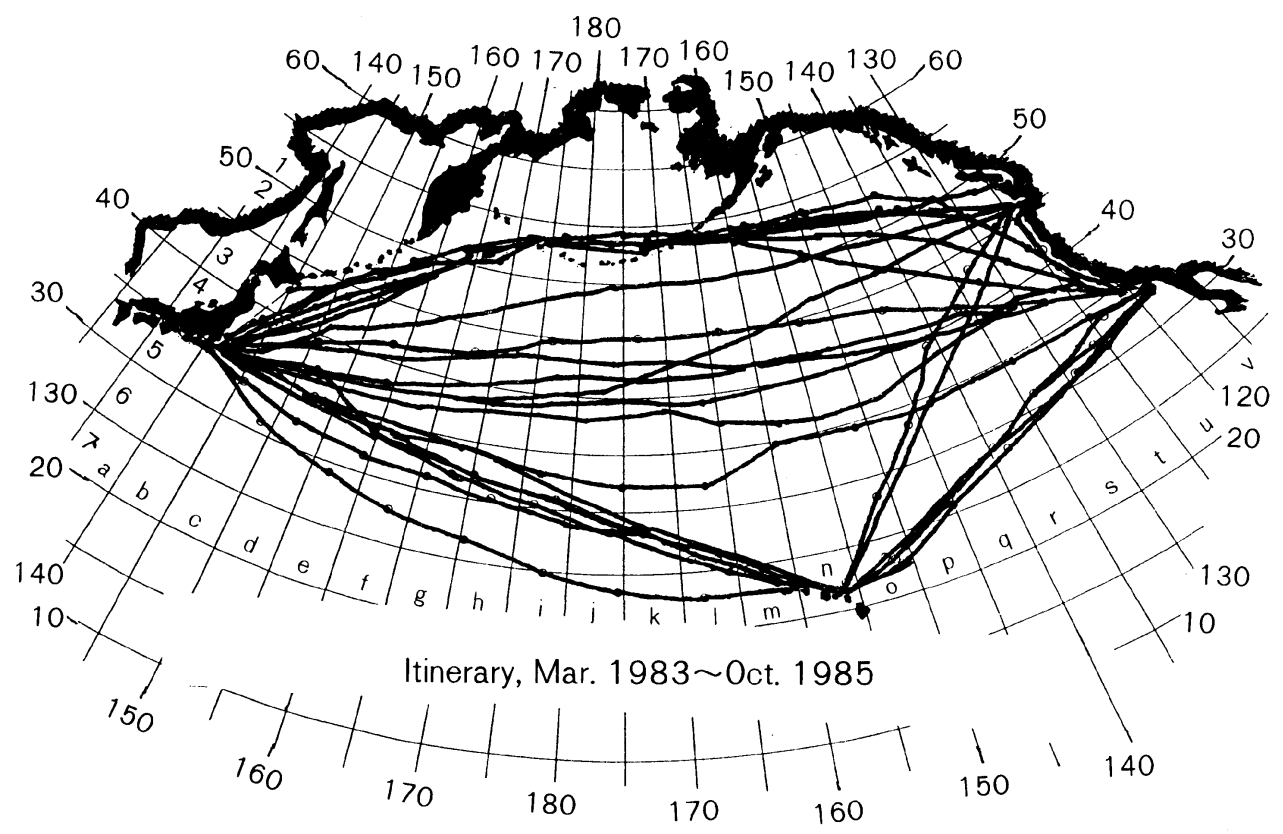

Fig 1. 11 round navigation courses.

$1 \sim 7$ longitudinal code $\quad a \sim v$ latitudinal code 


\section{Results}

The 41 species of Procellariiformes recorded comprised: Diomedeidae 2, Procelleriidae 29 (Fulmar 1, Gadfly-petrels 15, Bulwer's Petrel 1, Shearwaters 12) and Hydrobatidae 10. They are listed in Table 1, classified by distributional patterns derived from our data, and short description for each distributional pattern is given below.

1. Boreal to temperate dispersal pattern (Fig. 2) (Appendix I, 1)

This distributional pattern was shown typically by cool-adapted alcids and gulls, and procellariids were only represented by Fulmarus glacialis and Oceanodroma furcata, occurring from $0^{\circ} \mathrm{C}$ to $23^{\circ} \mathrm{C}$ (Fulmarus once $27^{\circ} \mathrm{C}$ ), south to $40^{\circ} \mathrm{N}$, but sporadic further south.

2. Temperate to subtropical dispersal pattern (Fig. 3) (Appendix I, 2)

a. Northern hemisphere breeders

Oceanodroma leucorhoa replaced $O$. furcata in lower boreal zone and was widely dispersed over North Pacific south to subtropical Hawaiian waters, with water temperature range $3^{\circ}-27^{\circ} \mathrm{C}$.

Two albatrosses, Diomedea immutabilis and D. nigripes, which breed on subtropical islands in winter, were recorded over whole North Pacific with specific different patterns, marking water temperatures $2^{\circ}-26^{\circ} \mathrm{C}$ (immutabilis) and $3^{\circ}-29^{\circ} \mathrm{C}$ (nigripes) (Kuroda 1988).

b. Southern hemisphere migrants (see $5, \mathrm{~b}$ )

3. Coastal patterns (Fig. 4) (Appendix I, 3)

a. Japanese side

Calonectris leucomelas super-dominated other seabirds of coastal distribution along Japan, showing its warm current dependence, and marked water temperatures $13^{\circ}-30^{\circ} \mathrm{C}$.

Oceanodroma castro and $O$. tristrami extended their ranges from Japanese coast to Hawaiian waters, while $O$. monorhis and $O$. matsudairae, with very few records, were coastally restricted (one record of monorhis in $5 \mathrm{i}$ mesh). Their water temperature records were $4^{\circ}-30^{\circ} \mathrm{C}, 11^{\circ}-26^{\circ} \mathrm{C}, 19^{\circ}-23^{\circ} \mathrm{C}$ and $18^{\circ}-25^{\circ} \mathrm{C}$, respectively. $O$. monorhis and $O$. matsudairae are warm adapted species, migrating to Indian Ocean.

b. North American side

On U.S. west coast, more local endemic species (than on Japanese coast) are distributed along warm temperate to subtropical zones. They are: Puffinus opisthomelas, $P$. auricularis, Oceanodroma melania, O. homochroa (O. markhami and Halocyptena microsoma were not recorded) and Puffinus creatopus which is a southern hemisphere breeder. Their water temperature records were: $15^{\circ}-22^{\circ} \mathrm{C}, 13^{\circ}-18^{\circ} \mathrm{C}, 17^{\circ}-24^{\circ} \mathrm{C}$ and $4^{\circ}-$ $21^{\circ} \mathrm{C}$ (P. creatopus).

4. Subtropical endemic patterns (Fig. 5) (Appendix I, 4)

a. Hawaiian endemic

Puffinus newelli and Pterodroma phaeopygia are two Hawaiian endemics, with water temperature records $23^{\circ}-28^{\circ} \mathrm{C}$ and $16^{\circ}$ (rarely $11^{\circ}$ and $12^{\circ} \mathrm{C}$ ) $-28^{\circ} \mathrm{c}$, respectively. 
Table 1. Distributional patterns of Procellariiformes recorded in transpacific pelagic surveys, 1983-85.

1. Boreal to temperate dispersal pattern (Fig. 2) (Appendix I, 1)

1) Fulmarus glacialis

2) Oceanodroma furcata

2. Temperate to subtropical dispersal patterns (Fig. 3) (Appendix I, 2)

a. Northern hemisphere breeders

(Diomedea albatrus, not recorded)

1) Diomedea nigripes (breeds on subtropical islands)

2) Diomedea immutabilis (breeds on subtropical islands)

3) Oceanodroma leucorhoa (breeds on subarctic islands)

[b. Southern hemisphere migrants: see 5-b]

3. Coastal patterns (Fig. 4) (Appendix I, 3)

a. Japanese side

1) Calonectris leucomelas (migrates to south Pacific and Indian Ocean)

2) Oceanodroma tristrami (east to Hawaiian waters)

3) Oceanodroma matsudairae (migrates to Indian Ocean)

4) Oceanodroma monorhis (migrates to Indian Ocean)

5) Oceanodroma castro (east to Hawaii, also Galapagos)

b. North American side

1) Puffinus creatopus (southern hemisphere breeder)

2) Puffinus opisthomelas (endemic)

3) Puffinus auricularis (endemic)

4) Oceanodroma melania (endemic)

5) Oceanodroma homochroa (endemic)

(Oceanodroma markhami, not recorded) (endemic)

(Halocyptena microsoma, not recorded) (endemic)

4. Subtropical endemic patterns (Fig. 5) (Appendix I, 4)

a. Hawaiian endemic

1) Pterodroma phaeopygia

2) Puffinus newelli

b. Subtropical endemic

1) Pterodroma hypoleuca

5. Subtropical to northward dispersal pattern (Fig. 6) (Appendix I, 5)

a. Tropical species (subtropical limitted)

1) Bulweria bulwerii

2) Pterodroma arminjoniana

3) Puffinus pacificus

4) Puffinus nativitatis

5) Puffinus lherminieri

b. Southern hemisphere migrants

b-1. Subtropical limitted

1) Pterodroma neglecta

2) Pterodroma externa externa

3) Pterodroma externa cervicalis

4) Pterodroma longirostris

5) Pterodroma nigripennis

6) Pterodroma cookii

7) Pterodroma pycrofti

b-2. North to temperate zone (south of Aleutians)

1) Pterodroma solandri

2) Puffinus carneipes

3) Puffinus bulleri

4) Puffinus griseus (also, coastally abundant)

b-3. North into Bering Sea

1) Puffinus tenuirostris (also, coastally abundant)

2) Pterodooma inexpectata 


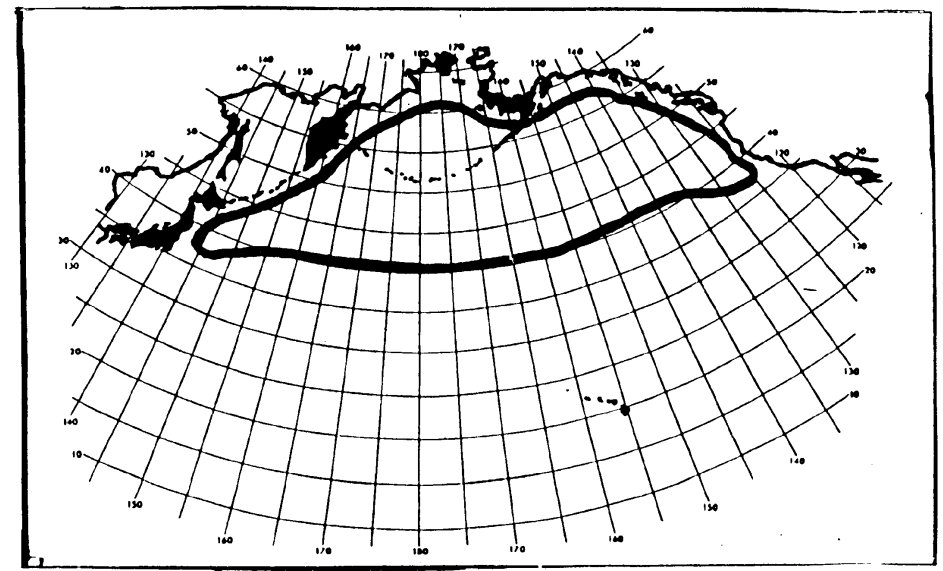

Distributional pattern 1 .

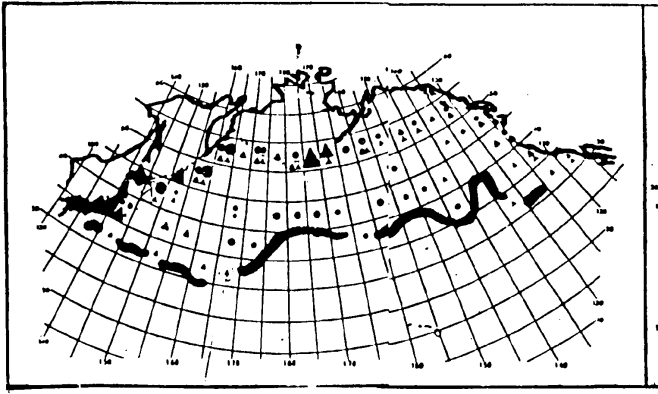

1. Fulmarus glacialis

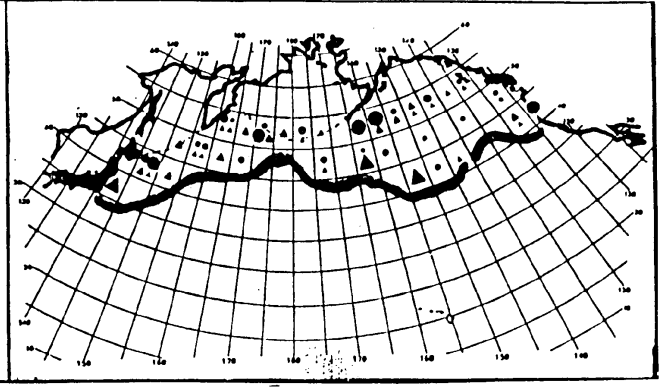

2. Oceanodroma furcata

Fig. 2. Boreal to temperate dispersal pattern (Appendix I, 1).

\section{b. Subtropical endemic}

Pterodroma hypoleuca was the only subtropical endemic species representing the Genus Pterodroma as the northernmost and commonest species in the North Pacific, distributed south of $40^{\circ} \mathrm{N}$ from southern offshores of Japan to Hawaiian waters, with preferved water temperatures $12^{\circ}-30^{\circ} \mathrm{C}$.

5. Subtropical to northward dispersal pattern (Fig. 6) (Appendix I, 5)

a. Tropical species (subtropical limitted)

Many tropical seabirds, such as, terns, frigatebirds, tropicbirds and boobies, occurred in this zone as their northern limit. In Procellariiformes, Puffinus lherminieri (water temperature records $24^{\circ}-25^{\circ} \mathrm{C}$ ) and Pterodroma arminjoniana (one record) were examples, and Puffinus nativitatis was sparcely, but widely distributed, while Bulweria bulwerii was recorded in Hawaiian and southern Japanese waters separately, both species with water temperatures $19^{\circ}-30^{\circ} \mathrm{C}$. Puffinus pacificus was the only tropical species of wide subtropical (south of $40^{\circ} \mathrm{N}$ ) distribution, with water temperature range of $19^{\circ}$ (also one 


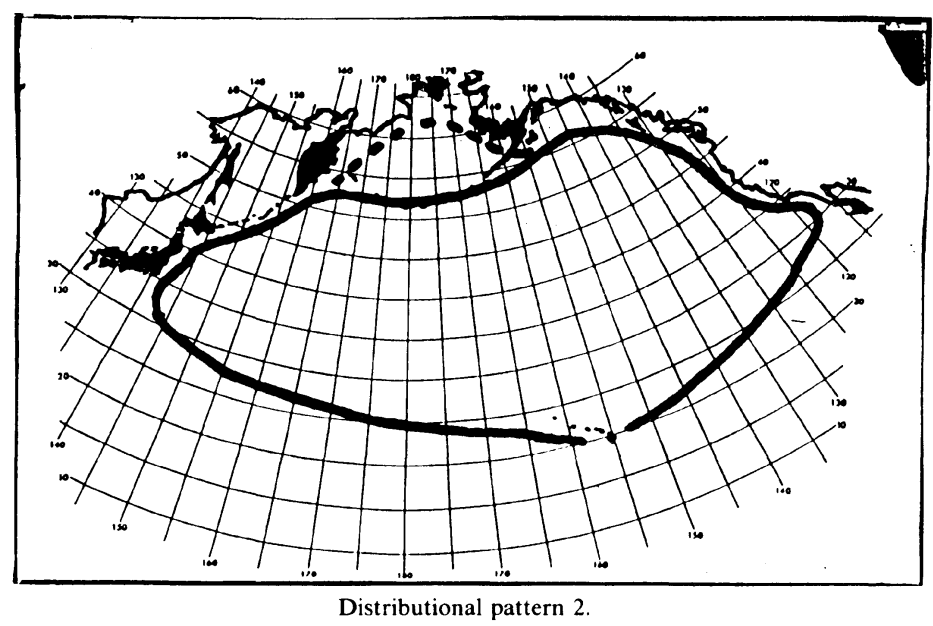

a. Northern hemisphere breeders.

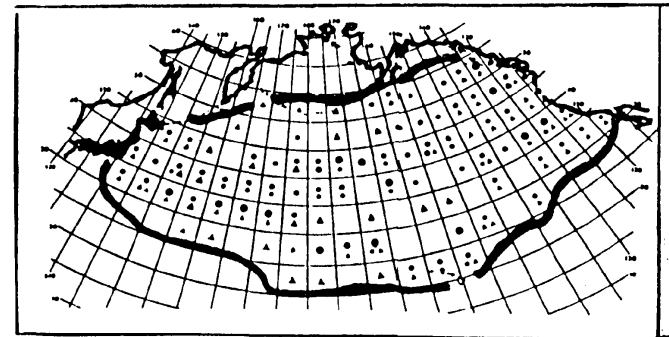

1. Diomedea nigripes

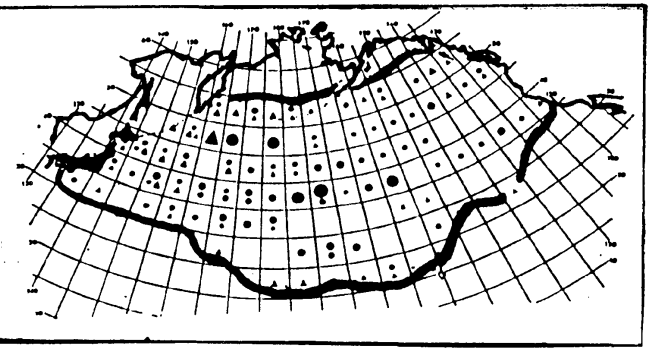

2. Diomedea immutabilis

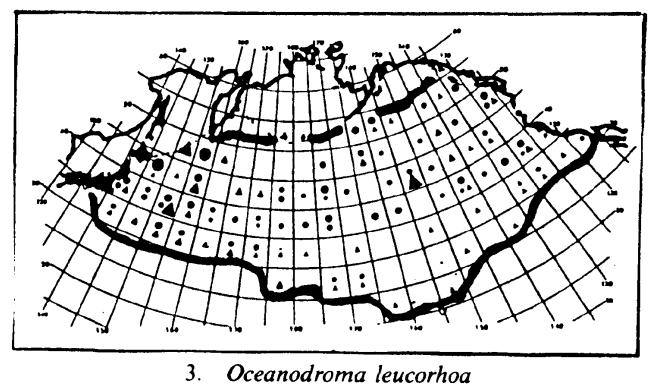

Fig. 3. Temperate to subtropical dispersal patterns (Appendix I, 2).

[b. Southern hemisphere migrants. see Fig. 6-b]

record each for $15^{\circ} \mathrm{C}$ and $16^{\circ} \mathrm{C}$ ) $-30^{\circ} \mathrm{C}$.

b. Southern hemisphere migrants

b-1. Subtropical limited

Most of southern hemisphere migrants of Pterodroma restricted themselves within 


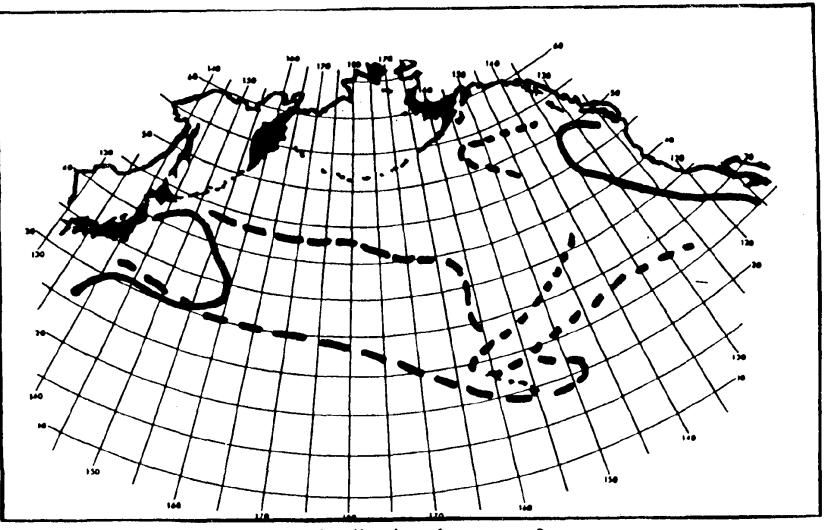

Distributional pattern 3.

Japanese side.
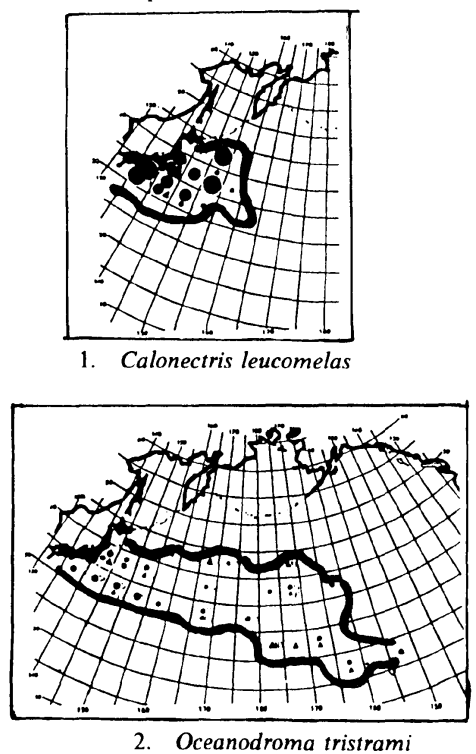

U.S. west coast.

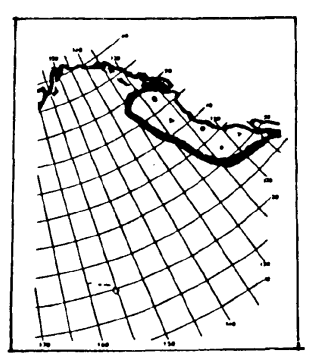

1. Oceanodroma melania

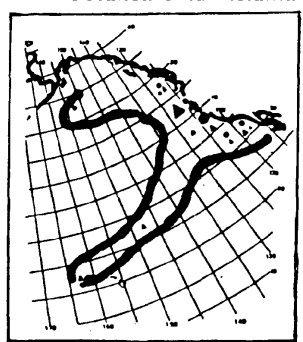

2. Puffinus creatopus

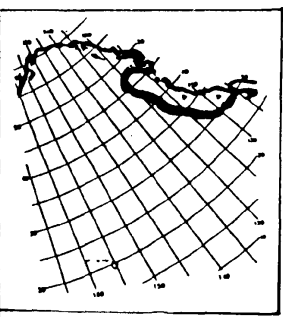

3. Puffinus auricularis

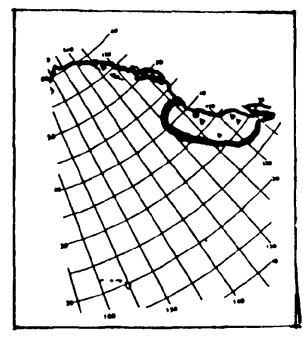

4. Puffinus opisthomelas

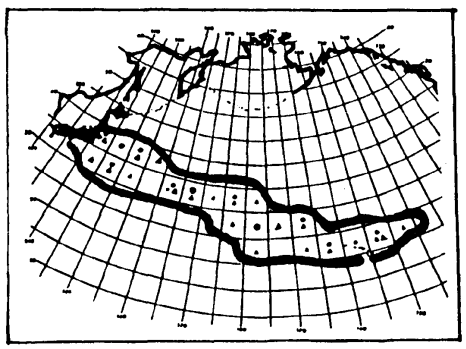

5. Oceanodroma castro

(3, 4 are not given)

Fig. 4. Coastal patterns (Appendix I, 3). 


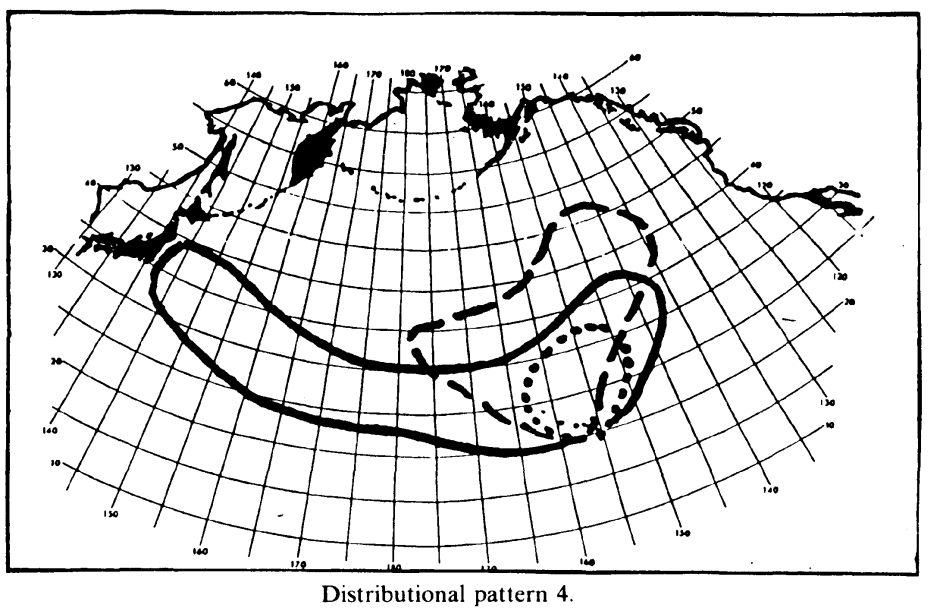

a. Hawaiian endemics.

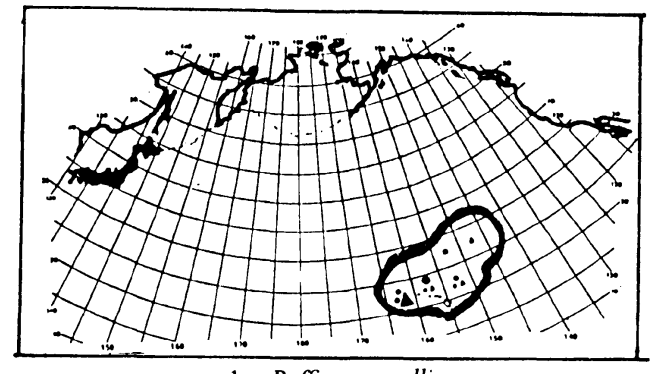

1. Puffinus newelli

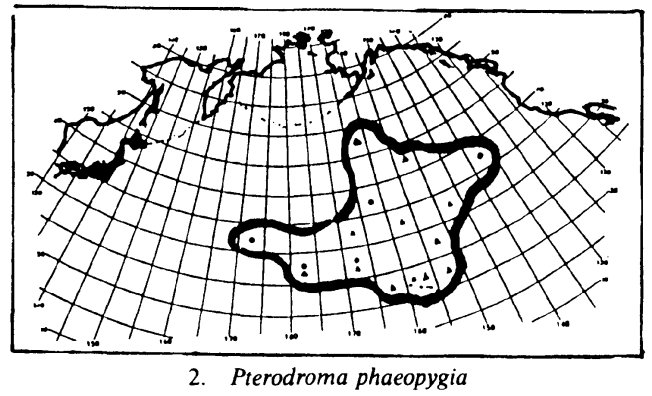

2. Pterodroma phaeopygia

b. Subtropical endemic.

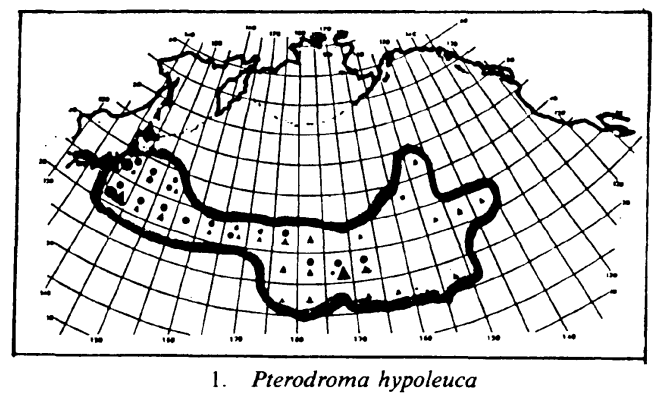

Fig. 5. Subtropical endemic patterns (Appendix I, 4).

subtropical zone with wide spread distribution south of $40^{\circ} \mathrm{N}$, more commonly occurring in western Pacific, Hawaii to Japanese waters. The water temperatures recorded for each species were: Pterodroma externa externa $11^{\circ}-29^{\circ} \mathrm{C}$, P. externa cervicalis (cf. Tanaka \& Inaba 1981, Brazil 1988$) 20^{\circ}-30^{\circ} \mathrm{C}, P$. neglecta $13^{\circ}-30^{\circ} \mathrm{C}, P$. nigripennis $12^{\circ}-29^{\circ} \mathrm{C}, P$. 


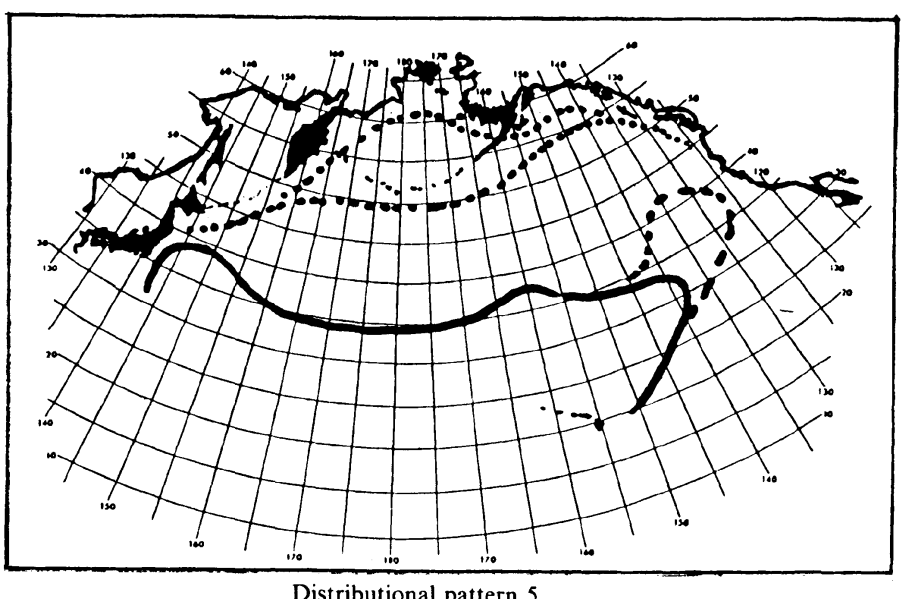

a. Tropical species.

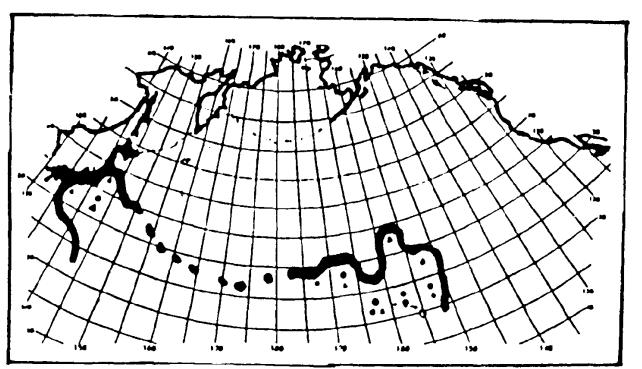

1. Bulweria bulwerii

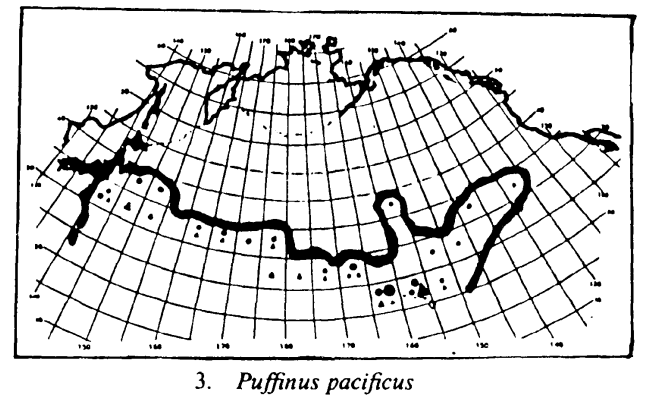

3. Puffinus pacificus

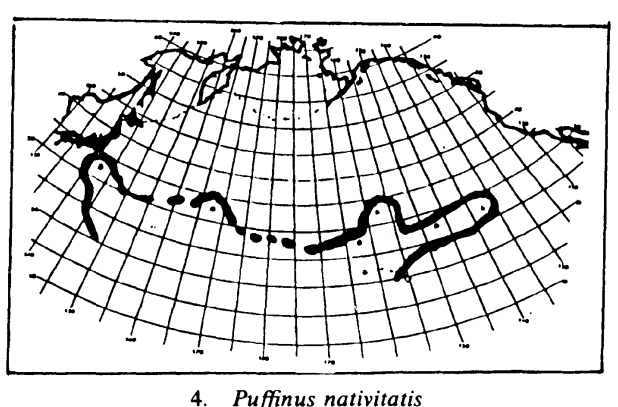

4. Puffinus nativitatis

(2. Pterodroma arminjoniana and 5. Puffinus lherminieri are not given)

Fig. 6. Subtropical to northward dispersal patterns (Appendix I, 5).

longirostris $13^{\circ}-30^{\circ} \mathrm{C}$, P. pycrofti $24^{\circ}-29^{\circ} \mathrm{C}$ and $P$. cooki $12^{\circ}-29^{\circ} \mathrm{C}$.

b-2. North to temperate zone (south of Aleutians)

Puffinus griseus and $P$. tenuirostris were the two species superabundant in the whole North Pacific including coastal waters, but with different distributional concentrations, $P$. 
b. Southern hemisphere migrants.

b-1. Subtropical limitted.

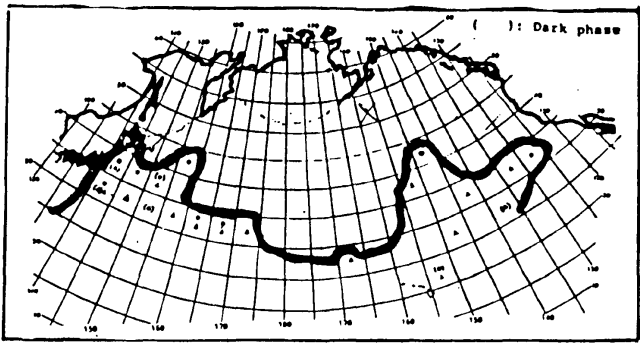

1. Pterodroma neglecta

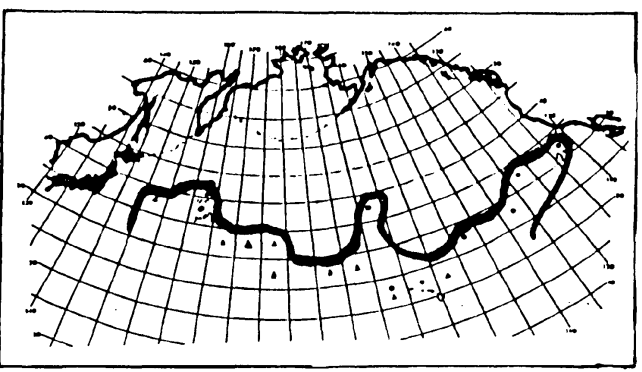

2. Pterodroma externa externa

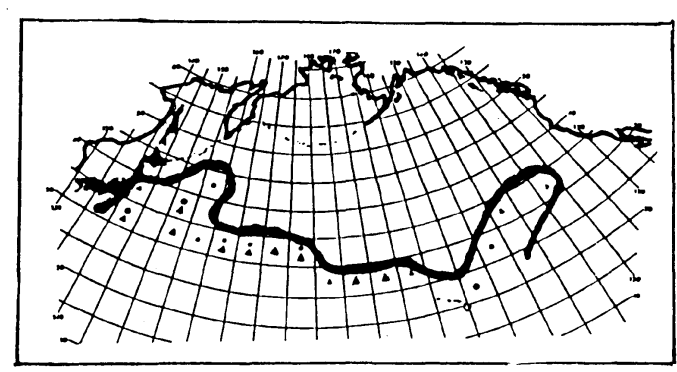

3. Pterodroma externa cervicalis
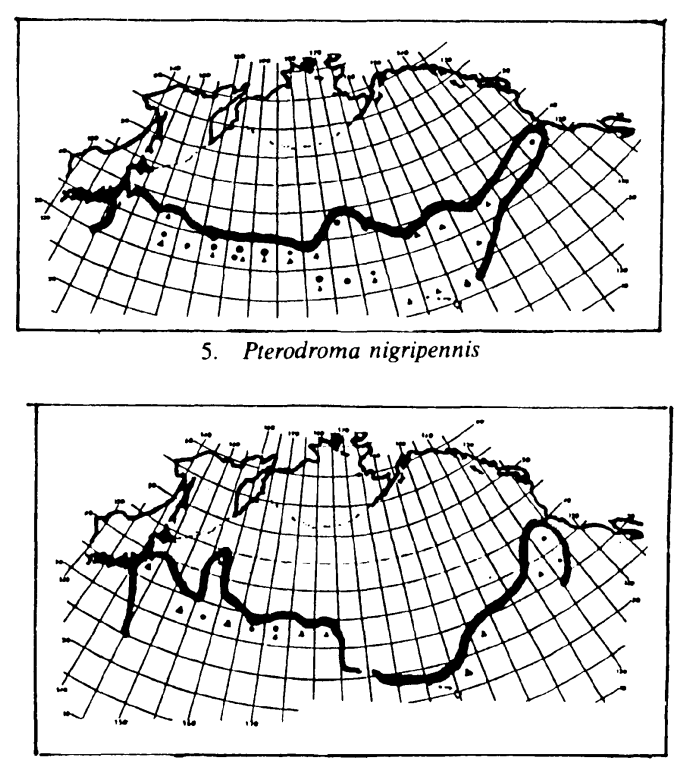

6. Pterodroma cooki

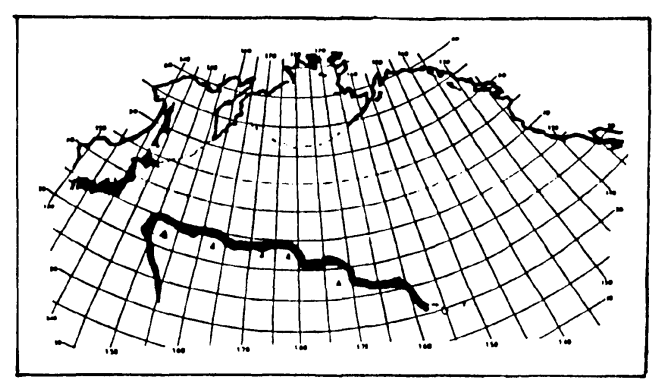

7. Pterodroma pycrofti

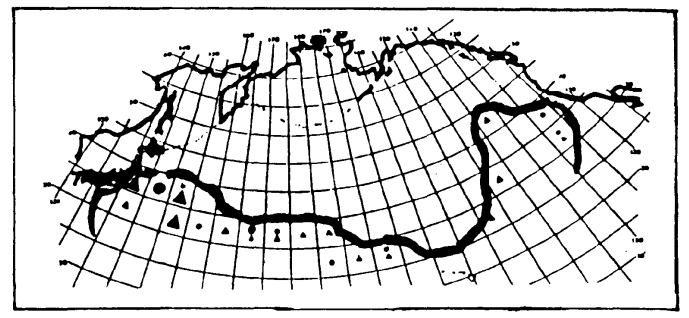

4. Pterodroma longirostris

Fig. 6. (continued)

tenuirostris in cooler Kuriles to Aleutian waters where $P$. griseus was scarce and this species dominated along $40^{\circ} \mathrm{N}$ and southward. Its particular abundance on U.S. coast would show the mixture of its South American breeding populations. The water 
b-2. North to temperate zone.

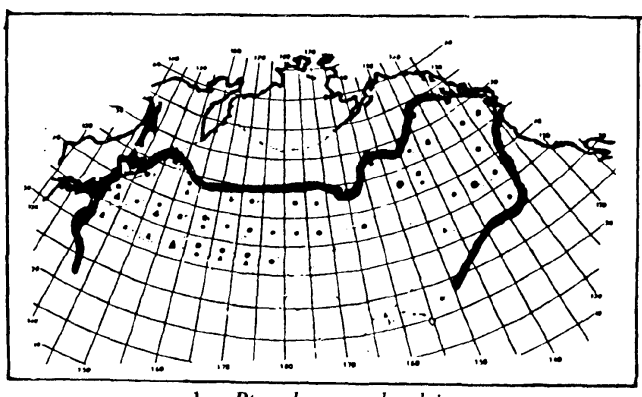

1. Pterodroma solandri

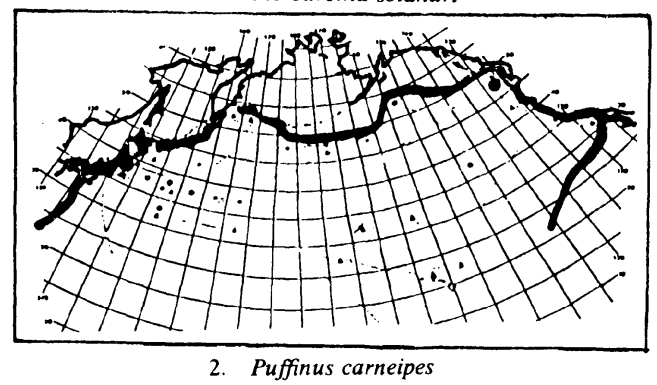

2. Puffinus carneipes
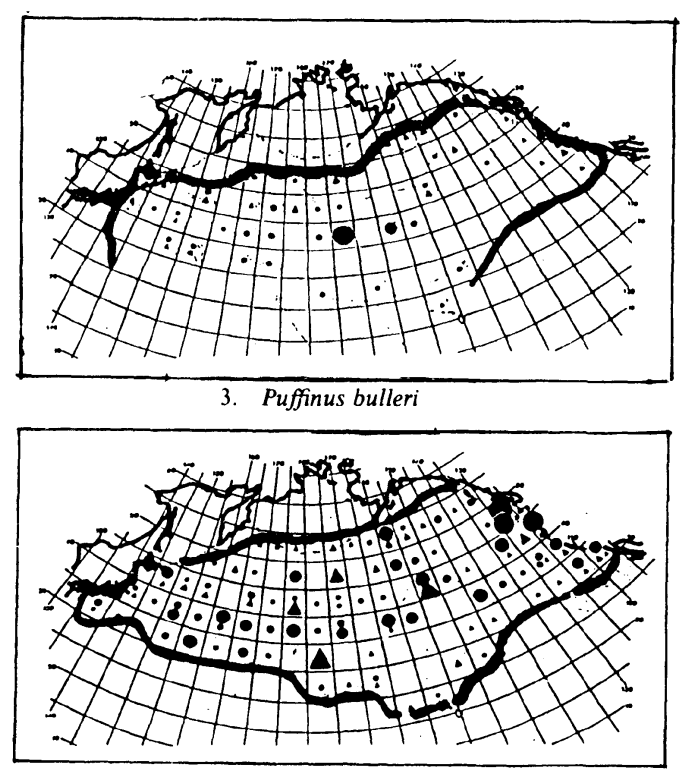

4. Puffinus griseus

b-3. North into Bering sea.

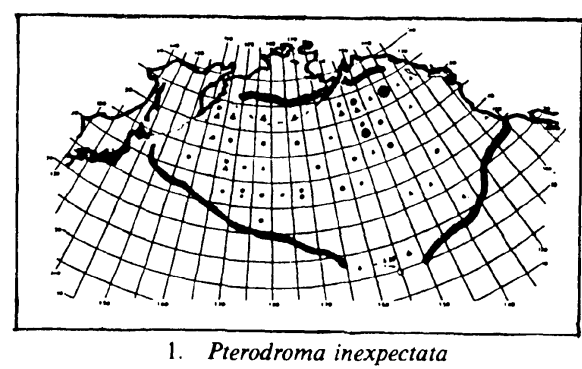

Fig. 6. (continued)

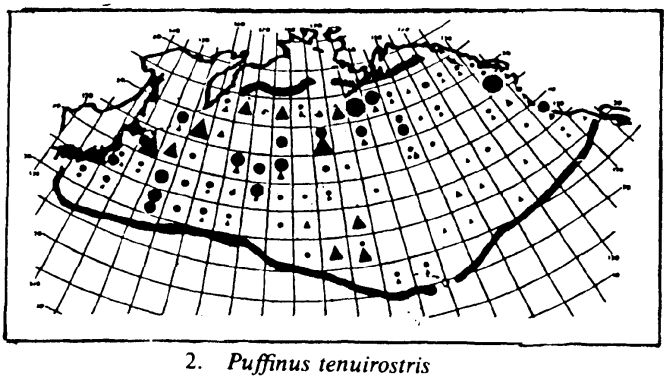

2. Puffinus tenuirostris

temperature records were $2^{\circ}-29^{\circ} \mathrm{C}$ and $4^{\circ}-28^{\circ} \mathrm{C}$ for $P$. tenuirostris and $P$. griseus, respectively.

Other wide distributed species in the temperate zone were Puffinus carneipes, $P$. bulleri and Pterodroma solandri (cf. Tanaka 1986), but their main dispersal ranges were south of $50^{\circ} \mathrm{N}$, and the water temperatures recorded were $3^{\circ}-25^{\circ} \mathrm{C}, 9^{\circ}-26^{\circ} \mathrm{C}$ and $3^{\circ}-30^{\circ} \mathrm{C}$ for respective species. Pterodroma inexpectata was distributed in the central Pacific with northward spread to cooler waters, with water temperatures $3^{\circ}-22^{\circ} \mathrm{C}$.

b-3. North into Bering Sea

Only two species, Pterodroma inexpectata and Puffinus tenuirostris, invaded into Bering Sea, though our observation was restricted to the Aleutian waters. They are known to reach north to Bering Strait. 


\section{Discussions}

Procellariiformes, as the most pelagic seabirds, are distributed over whole North Pacific Ocean with wide flight range and seasonal movements, 13 out of 35 species recorded being migrants from the southern hemisphere.

Their distributional patterns were classified into: 1 . Northern cold current distribution ( 2 spp.) 2. Wide temperate to subtropical distribution (3 northern hemisphere and 6 southern hemisphere ( 3 species into Bering Sea) species) 3. Coastal distribution (5 on Japanese and 6 ( 2 species not recorded this time) on U.S. west coasts) 4. Central subtropic distribution (includes 2 Hawaiian endemic species, and 3 tropical species which occurred as their northern limit) 5. Subtropical wide distribution (includes 1 subtropical endemic, 3 tropical species and 7 southern hemisphere migrants).

Seasonally, the number of species recorded were few in winter, being 4 in February, 11 in March and increased from 18 in April, 28 in May and June, 30 in August and September, 26 in October to 32 in November, decreasing to 15 in January. Only northern residents were recorded all months and southern hemisphere migrants began to arrive in North Pacific, few in March increasing through April and May, and reaching to abundance of August to November. This is also correlated with number of birds and therefore biomass, the peak density of concentrations occurring locally in high productive sea areas where mixed flocks of a few dominant seabird species (always including Procelleriids) formed high density feeding assemblies. The sea area of largest concentration was the eastern Aleutian waters around Alaskan Peninsula, and the number of species and density were high along coastal zones both of Japanese and U.S. sides. Details will be analysed in the co-authored main report (in preparation) in which the zonation of the North Pacific will be proposed based on seabird abundance.

Related species pairs, as reported in the albatrosses Diomedea immutabilis vs. D. nigripes (Kuroda 1988), locally replaced their concentration sea areas, or differed in distributional patterns, concentrated or diffused, possibly by temperature and food preference, or mutual interference. Such cases were found in Puffinus griseus vs. P. tenuirostris, Oceanodroma furcata vs. $O$. leucorhoa, $O$. castro and $O$. tristrami vs. $O$. monorhis and O. matsudairae.

In southern hemisphere migrants, the seasonal advance of migration front in North Pacific was suggested by connecting the monthly records (Appendix II). As for Puffinus tenuirostris details will be analysed elsewhere (Oka 1986; MS, Degawa \& Watabe 1983). In Puffinus griseus, U.S. coastal population of South American origin and western to central Pacific population of New Zealand origin were separable in their seasonal movements. In $P$. bulleri, the northward movements of migration front were suggested from May and June to August, staying in the same sea area until September. Pterodroma solandri seems to be early in migration, some had occurred in North Pacific already in March to April. But, fronts of later migrants (possibly young) arrive in May, moving northward through June to August. From September to October a movement to Japanese offshore is noted and November records are found east to Hawaiian waters. In Puffinus 
carneipes, spring occurrence, March (or February, Martins 1988) to May, to Japanese waters is marked even entering Japan Sea (as shown by banding recoveries, Bird Migr. Res. Center 1985), following the Tsushima warm current. In June, it was recorded in Japan-Kamchatkan waters southeast of the Kuriles. Then in August, movements along south of the Aleutians towards U.S. coast are suggestive and in November, this wide distributional front gradually shrinked toward eastern Hawaiian waters.

The main transequatorial migration lane of southern hemisphere petrels pass across this Hawaiian leeward sea area, where we saw southward migrating flocks of Puffinus tenuirostris on 6 and 7 November, 1983 and Mobberley (1974) (fide Harrison 1983) reports large flocks of Puffinus griseus (with fewer $P$. tenuirostris) and Pterodroma inexpectata migrating north in broad front during March to May.

The northward fronts of these southern hemisphere migrants are determined by temperature adaptation of each species. Puffinus tenuirostris and Pterodroma inexpectata penetrate into Bering Sea tolerating $2^{\circ} \mathrm{C}$ and $3^{\circ} \mathrm{C}$ water temperatures respectively, while Puffinus griseus tolerated to $4^{\circ} \mathrm{C}, P$. carneipes (once $3^{\circ} \mathrm{C}$ ) and Pterodroma solandri (once $3^{\circ} \mathrm{C}$ and $5^{\circ} \mathrm{C}$ ) usually to $7^{\circ} \mathrm{C}$, and $P$. bulleri and Pterodroma neglecta to $9^{\circ} \mathrm{C}$. These species reach north to convergence south of the Aleutians. Other southern migrants are more warm-adapted, their tolerable low water temperatures being: Pterodroma externa $17^{\circ}-20^{\circ}$ $\mathrm{C}$ (once $4^{\circ} \mathrm{C}$ (doubtful) and $11^{\circ} \mathrm{C}$ ), $P$. longirostris $18^{\circ} \mathrm{C}$ (once $13^{\circ} \mathrm{C}$ ), $P$. nigripennis $20^{\circ} \mathrm{C}$ (once $12^{\circ} \mathrm{C}$ and $15^{\circ} \mathrm{C}$ ), P. cooki $16^{\circ} \mathrm{C}$ (once $12^{\circ} \mathrm{C}$ ) and P. pycrofti $24^{\circ} \mathrm{C}$ (cf. Appendix III).

These tolerable limits of water temperature may be correlated with the species' temperature adaptation in their breeding sea areas in the southern hemisphere.

\section{Conclusion}

Procellariiformes comprise: the cold-adapted fulmar-group (of bi-polar distribution); the albatross-group wide ranging separated in northern and southern temperate sea zones; the chiefly warm-adapted shearwater-group resident in the tropical and migratory in the temperate zone, a few of them being transequatorial migrants; the principally tropical gadfly-petrel-group, some southern hemisphere species being transequatorial migrants to the North Pacific; the storm-petrel-group, with short-legged forms in the northern hemisphere and long-legged forms in the tropical zone to southern hemisphere; and the diving-petrel-group of the southern seas.

Their global distribution is adaptively correlated with water temperature, with the result that they can be grouped by distributional patterns and tolerable range and limit of temperature preference. Wide-ranging albatrosses and transequatorial migrant petrels show wide range of water temperature from $0^{\circ} \mathrm{C}$ or $2^{\circ}-3^{\circ} \mathrm{C}$ to $30^{\circ} \mathrm{C}$. Cold-adapted northern seabirds in general winter south to the sea area of water temperature $18^{\circ} \mathrm{C}$, while the northern limit of the range of warm-adapted species may be drawn by adaptive levels to water temperature; about $18^{\circ}-20^{\circ} \mathrm{C}$ in most warm-adapted species, about $7^{\circ}-10^{\circ} \mathrm{C}$ in moderately warm-adapted species and $0^{\circ}-3^{\circ} \mathrm{C}$ in least warm-adapted species reaching north into Bering Sea. 


\section{Acknowledgements}

The data used in this paper were collected by members of 'Study group of North Pacific seabirds' during transpacific navigations, 1983-1985. Here I give the members' names in acknowledgement of their contribution to this paper and maps: MM. I. Arita, M. Degawa, H. Fujimura, M. Kawaai, H. Kono, N. Kuroda (present author), N. Maruyama, H. Mochizuki, N. Oka, I. Skira and Y. Watanabe. This paper was presented at poster exhibition at XX I.O.C., 1990 (New Zealand), and the main report is under preparation by co-authorship, which was granted by Toyota Foundation, with kind cooperation of Toyota Motor Corporation and car-transport ships of Nihon Yusen, Toyofuji Kaiun, Chiyoda Kisen, Nihon Kisen and Fujiki Kaiun Co., Ltds.

\section{Selected References}

Bird Migr. Res. Center 1985. Japanese bird banding in recent years (1961-1983). 202 pp. Yamasina. Inst. Ornithol.

Brazil, M. A. 1988. The second record of White-necked Petrel Pterodroma externa cervicalis from Japan. J. Yamashina. Inst. Ornithol. 20: 52-53.

Degawa, M. \& Watabe, Y. 1983. Distribution of the Short-tailed Shearwater Puffinus tenuirostris in Japanese waters. Bull. Applied Orn. 3: 19-27.

Harrison, P. 1983. Seabirds. An identification guide. 448 pp. Croom Helm Ltd.

Kuroda, N. 1988. A distributional analysis of Diomedea immutabilis and D. nigripes in the North Pacific. J. Yamashina. Inst. Ornithol. 20: 1-20.

Martins, R. 1988. Selected bird observations from Japan: winter and spring 1980, with comments on distribution and status. J. Yamashina. Inst. Ornithol. 20: 54-56 (Early spring and winter records of $P$. carneipes).

Mobbeley (1974). From Harrison (1983): 241-242.

Oka, N. 1986. Observation on the emaciated and dead Short-tailed Shearwaters, Puffinus tenuirostris, in the north-western sea area of the North Pacific in 1983, J. Yamashina. Inst. Ornithol. 18: 63-67.

Oka, N. (Unpublished MS).

Shuntov, V. P. 1961. Migration and distribution of marine birds in southeastern Bering Sea during springsummer season. Zool. J. 40: 1058-1069.

Shuntov, V. P. 1968. Some regularities in distribution of albatrosses in the northern Pacific. Zool. J. 47: 10541064.

Shuntov, V. P. 1972. Seabirds and biological structure of the ocean. Uladivostok. $378 \mathrm{pp}$.

Tanaka, Y. 1986. Distribution and migration of the Solander's Petrel Pterodroma solandri in the North Pacific in relation to sea surface water temperature. J. Yamashina. Inst. Ornithol. 18: 55-62.

Tanaka, Y. \& Inaba, F. 1981. The distribution and migration of White-necked Petrel, Pterodroma externa cervicalis, in the west area of North Pacific Ocean and the Japanese waters. J. Yamashina. Inst. Ornithol. 13: 207-214.

\section{ミズナギドリ目の北太平洋の分布型と移動}

1983-85 年の間, 11 回の自動車輸出船による日米間太平洋往復鳥調査（研究グループ 14 名による）で得 られた観察記録から，ミズナギドリ目の 41 種 (アホウドリ科 2 種, ミズナギドリ科 29 種, ウミッバメ科 10 種）の洋上分布について, 次のようにまとめた。1. 亜寒帯から温帯海域への分散型（2 種）2. 温帯一亜熱帯 
の広域分散型（a. 北半球種 3 種, b. 南半球からの渡来種, 5-b 参照) 3. 沿岸分布型（a. 日本側 5 種：ハワイ 方面, インド洋などにも分散, b. 北アメリカ側 5 種：他に 2 種含み留鳥）4. 亜熱帯海域留鳥型（a. ハワイ 海域特泩 2 種, b. 亜熱帯全般型（特に日本一八ワイ間 1 種）５. 亜熱帯以北分散型 (a. 熱帯種北限分布 5 種, b. 南半球種： b-1. 亜熱帯海域まで 7 種， b-2. 温帯海域まで 4 種，b-3. ベーリング海まで 2 種）となる。 以上各種についての水温記録（月別）や南半球加ら渡来の 5 種についての月別分布移動も図示した。 この研究はトヨ夕財団助成金とトヨ夕自動車（株）のご好意による, 日本郵船, トヨフジ海運, 千代田汽 船, 日本汽船, 藤木海運の各社の自動車輸送船に便乗して行われた研究の一部である。なお，この報告は 1990 年度国際鳥学会議（ニュージーランド）でポスター発表した。

黑田長久：山階鳥類研究所 $\mathbf{2} 270-11$ 千葉県我孫子市高野山 
Appendix I. Distributional patterns of Procellariiformes recorded during transpacific survey 1983-85. Note: $\bigcirc$ Spring (Mar. May) Summer (June $\sim$ Aug.) $\triangle$ Autumn (Sep. $\sim$ Nov.)

$\Delta$ Winter (Dec. $\sim$ Feb. $)$

$0 \mathrm{n}<1 \bigcirc 1<\mathrm{n}<10 \bigcirc 10<\mathrm{n}<100 \bigcirc \mathrm{n}>100$

(Number of birds/hour. The same in the other marks)

1. Boreal to temperate dispersal pattern

1) Fulmarus glacialis

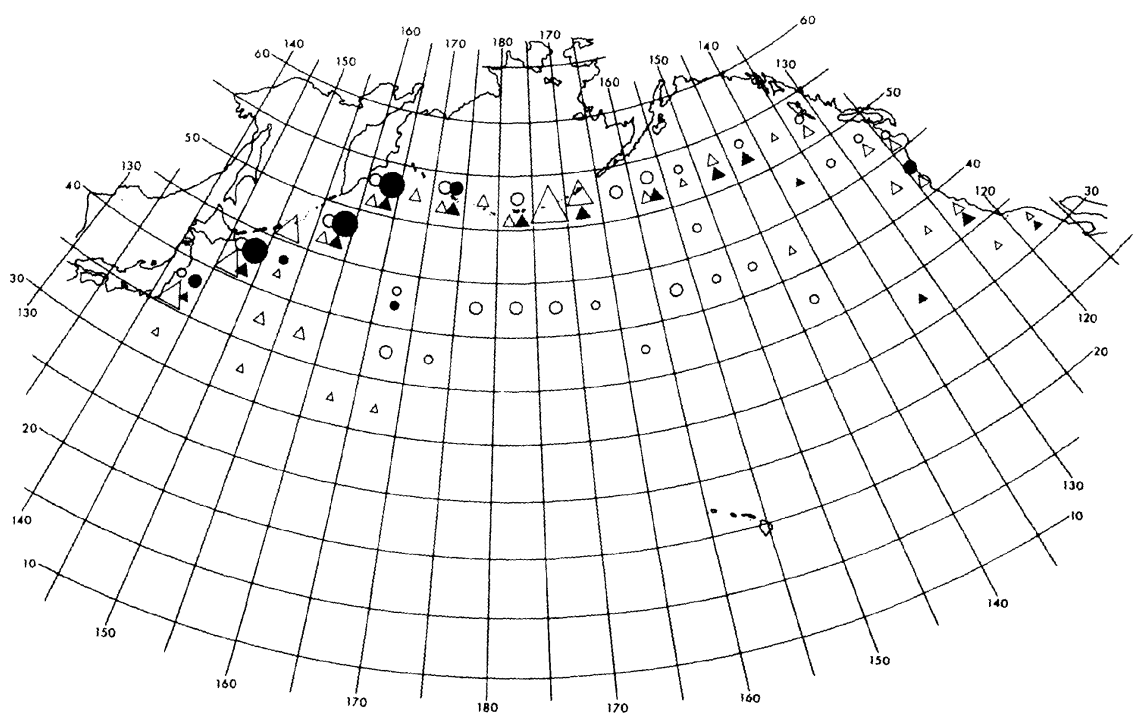

2) Oceanodroma furcata

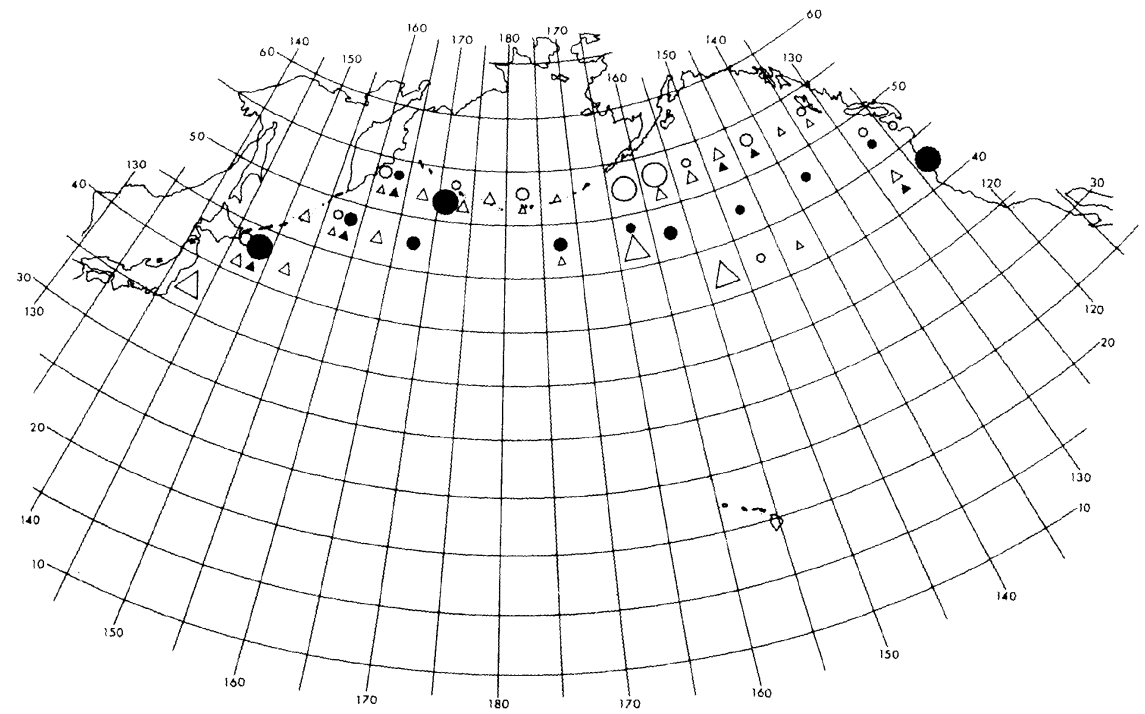


2. Temperate to subtropical dispersal patterns

a. Northern hemisphere breeders

1) Diomedea nigripes

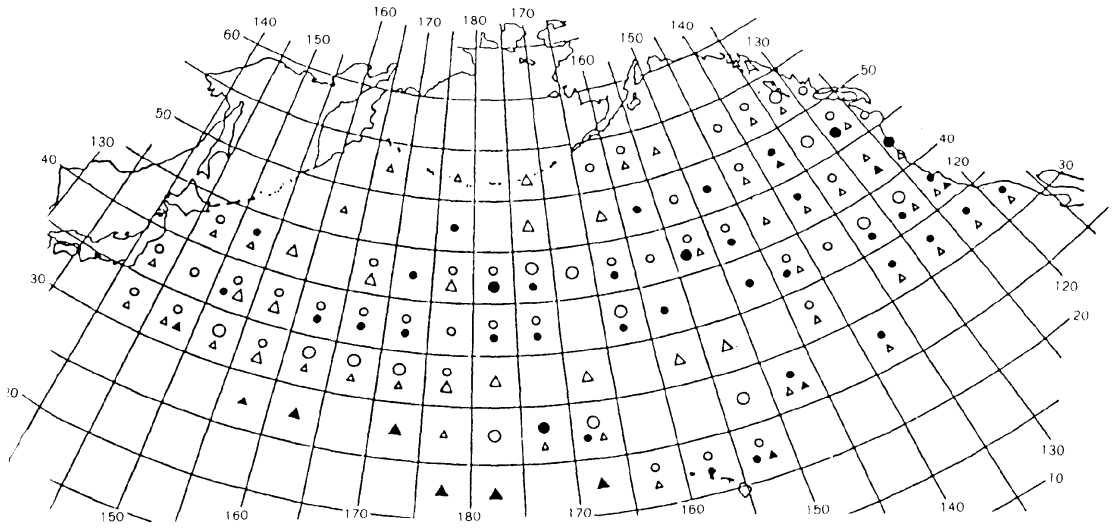

2) Diomedea immutabilis

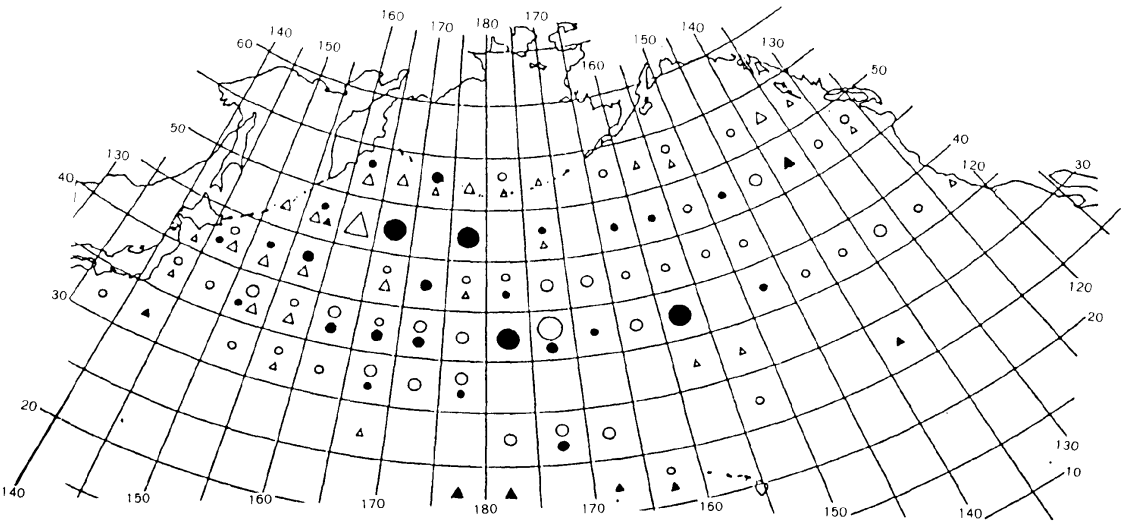

3) Oceanodroma leucorhoa

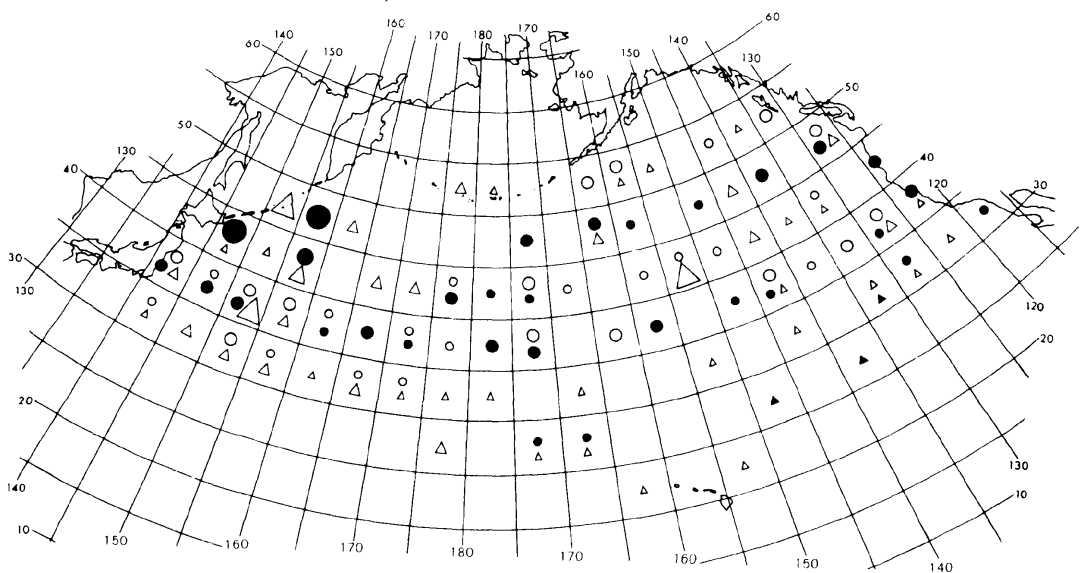

[b. Southern hemisphere migranto: see 5-b] 
3. Coastal patterns

a. Japanese side

1) Calonectris leucomelas

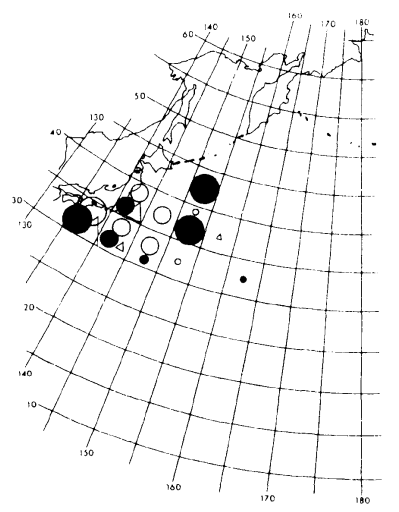

3) Oceanodroma matsudairae

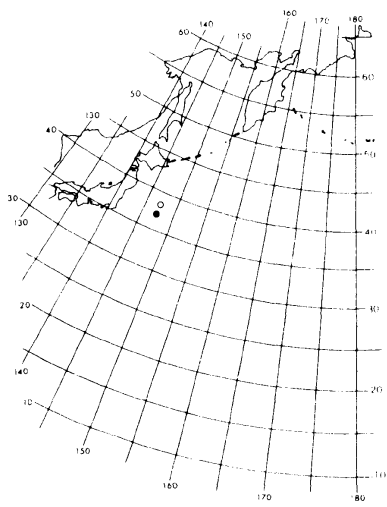

2) Oceanodroma tristrami
4) Oceanodroma monorhis

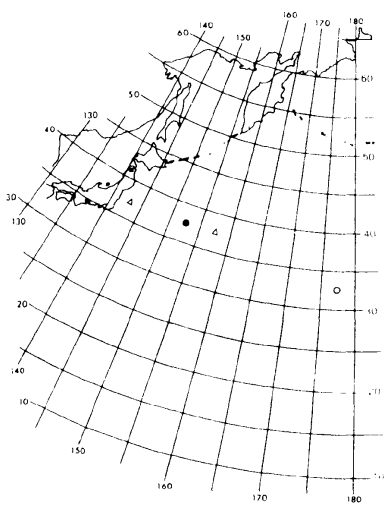

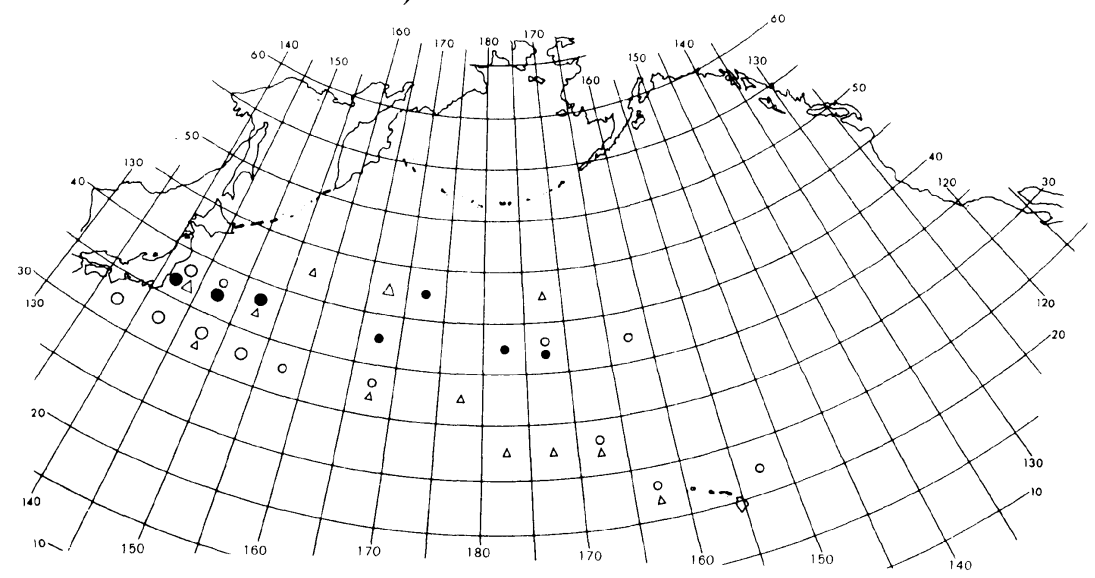

5) Oceanodroma castro

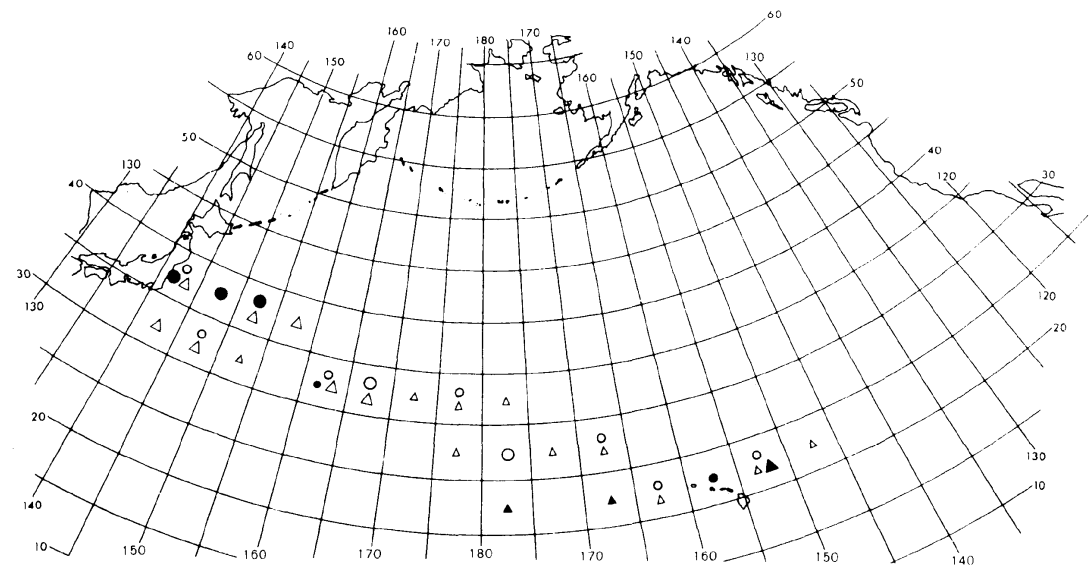


b. North American side

1) Puffinus creatopus

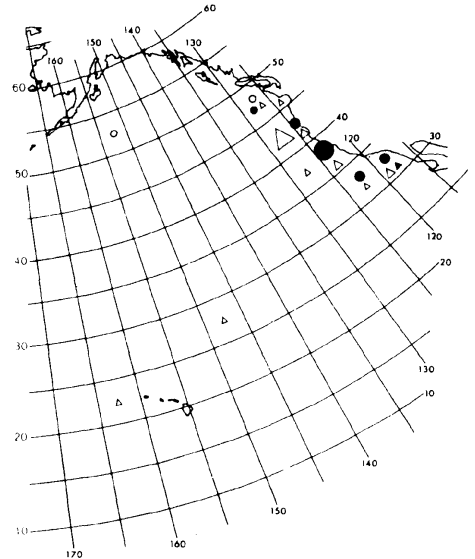

3) Puffinus auricularis

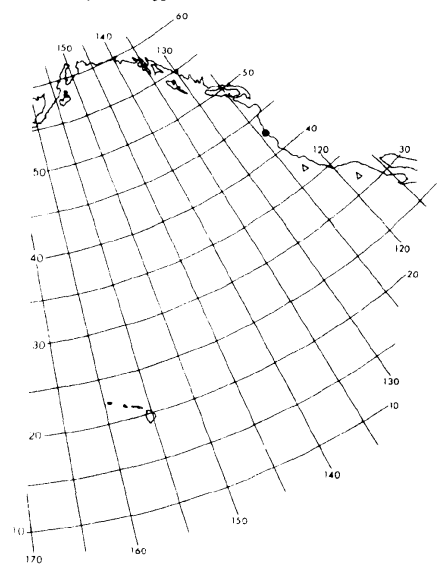

5) Oceanodroma homochroa

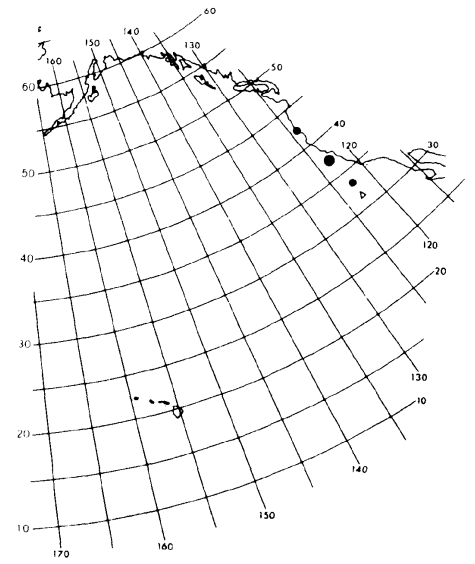

2) Puffinus opisthomelas

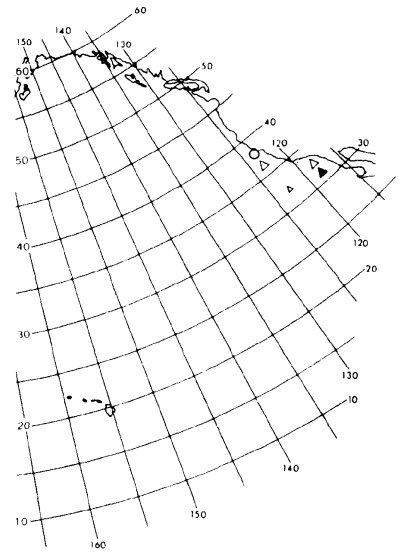

4) Oceanodroma melania

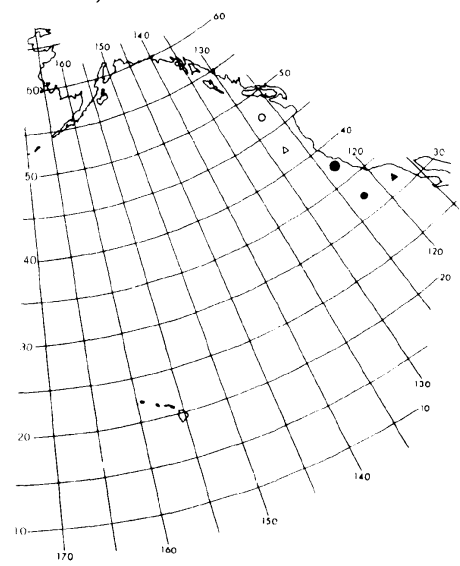


4. Subtropical endemic patterns

a. Hawaiian endemic

1) Pterodroma phaeopygia

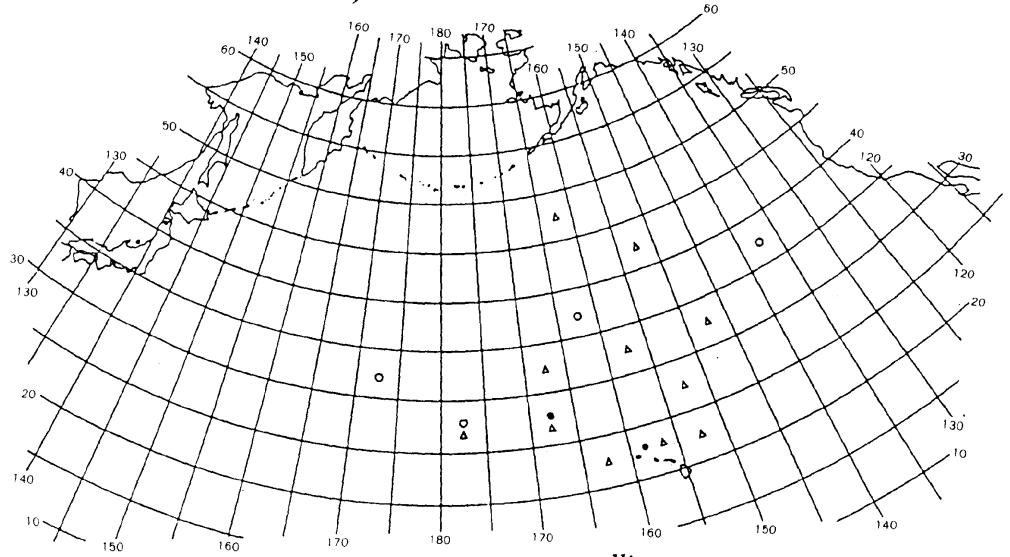

2) Puffinus newelli

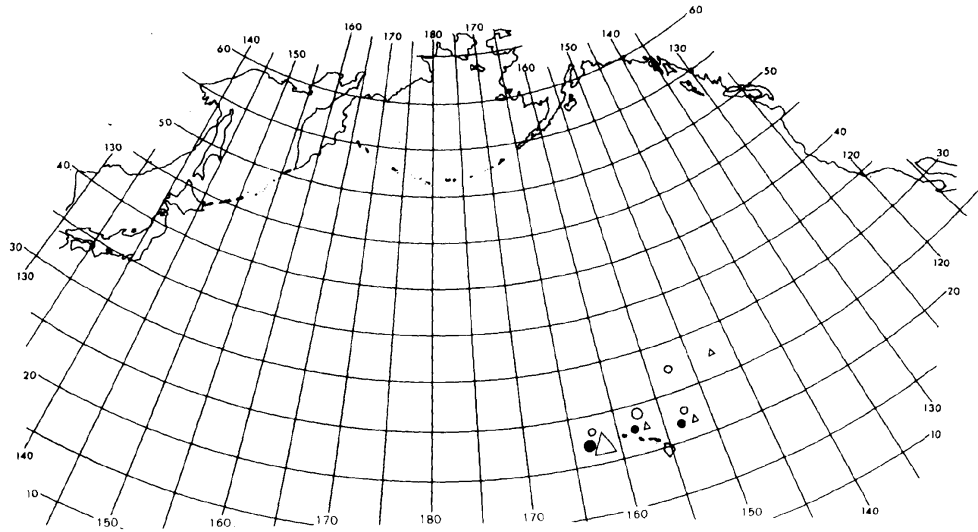

b. Subtropical endemic

1) Pterodroma hypoleuca

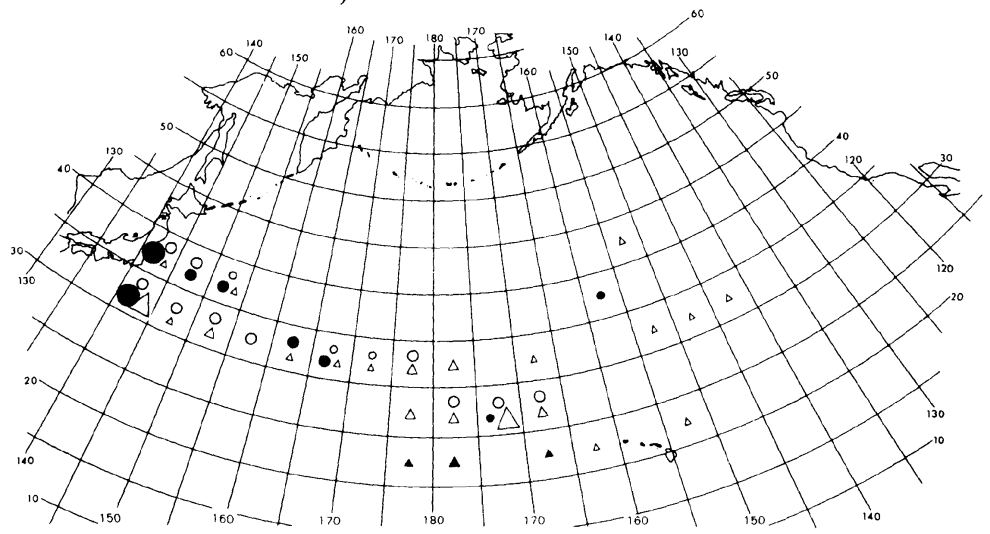


5. Subtropical to northward dispersal patterns

a. Tropical species (subtropical limitted)

1) Bulweria bulwerii

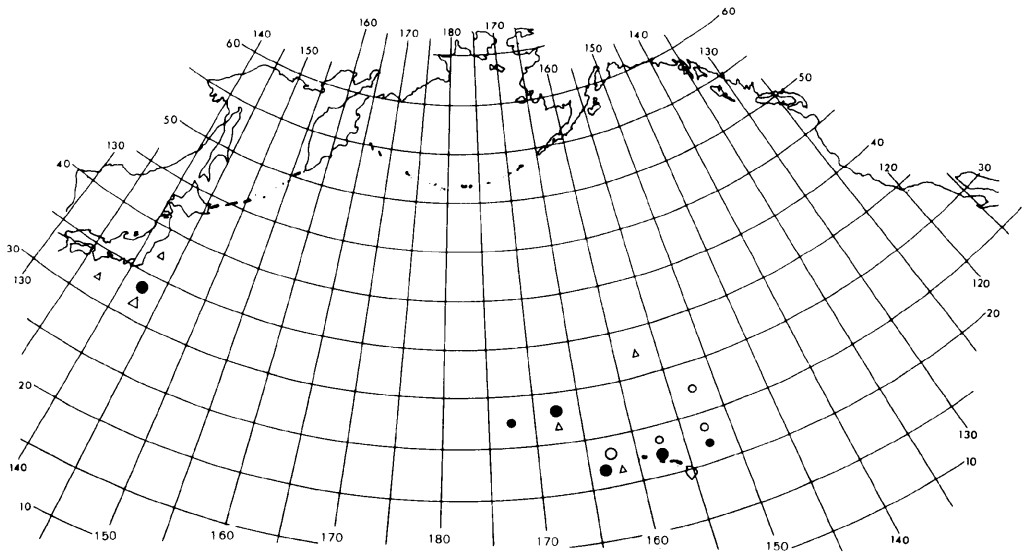

3) Puffinus pacificus

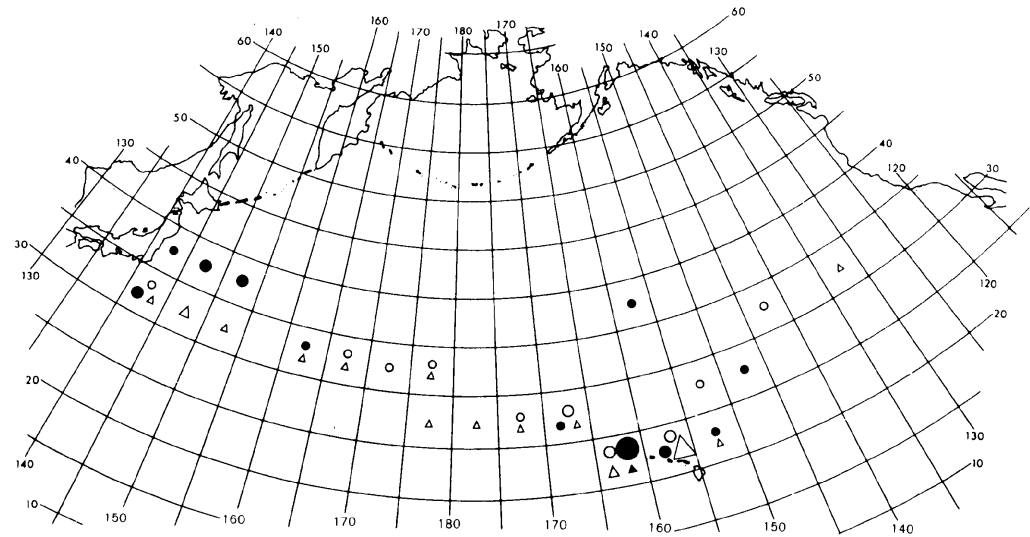

4) Puffinus nativitatis

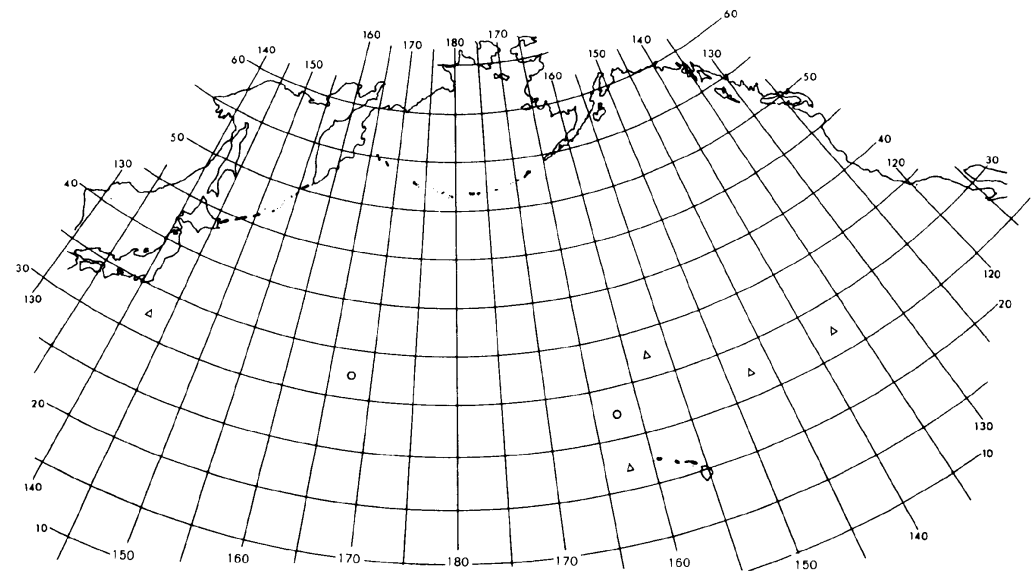


2) Pterodroma arminjoniana

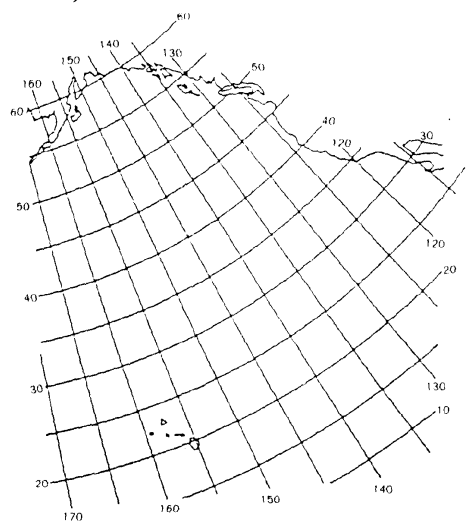

5) Puffinus lherminieri

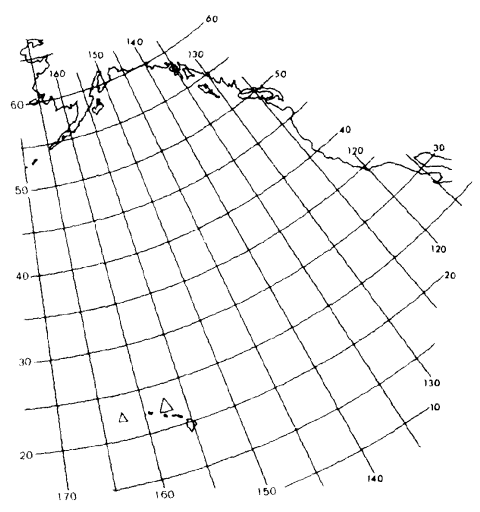

b. Southern hemisphere migrants b-1. Subtropical limitted

1) Pterodroma neglecta

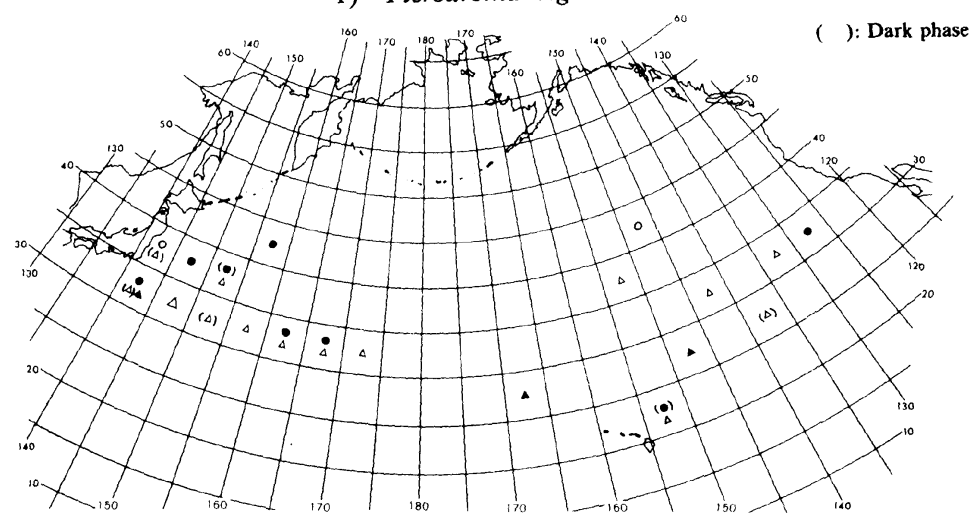

2) Pterodroma externa externa

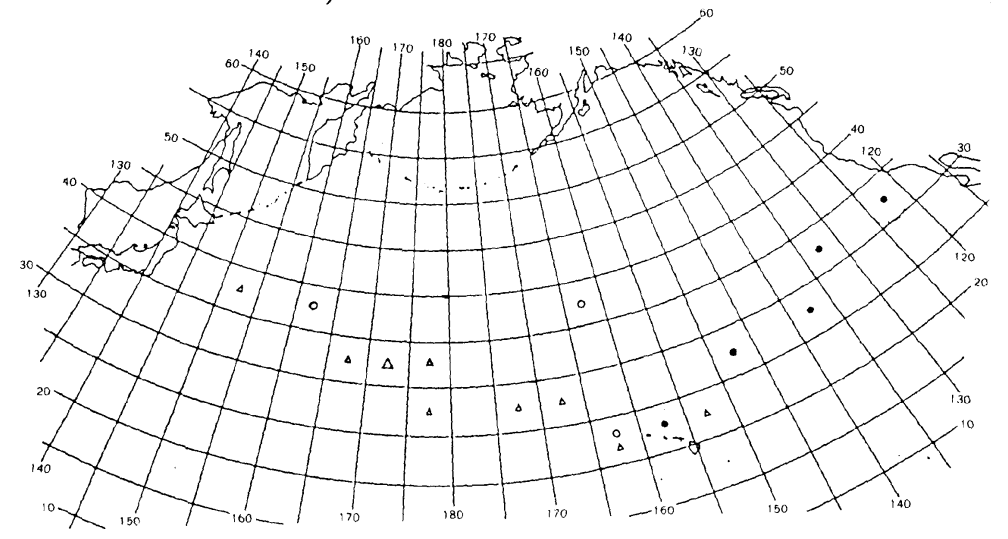


Procellariiformes in the North Pacific

3) Pterodroma externa cervicalis

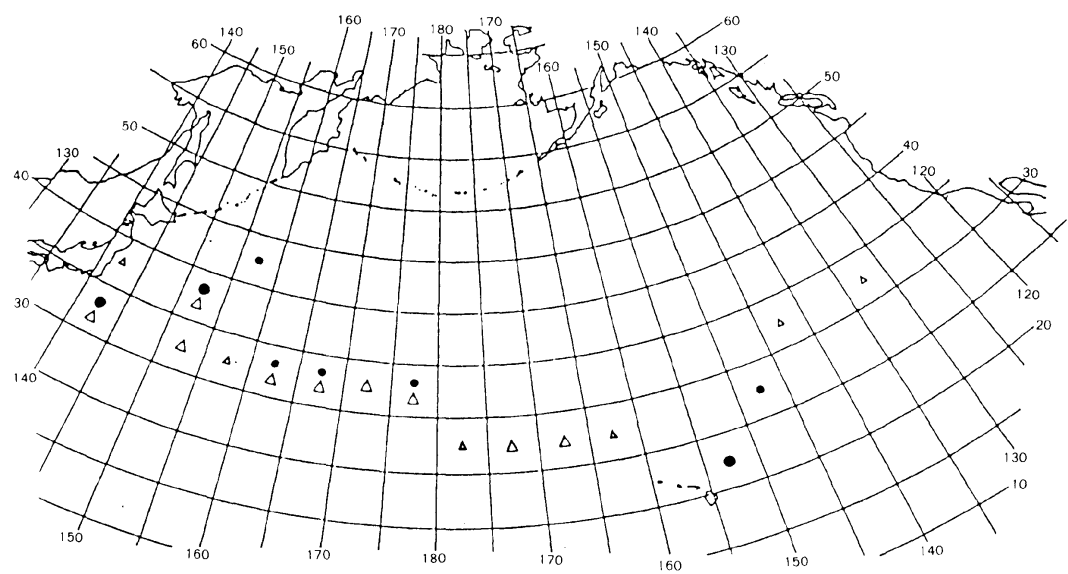

4) Pterodroma longirostris

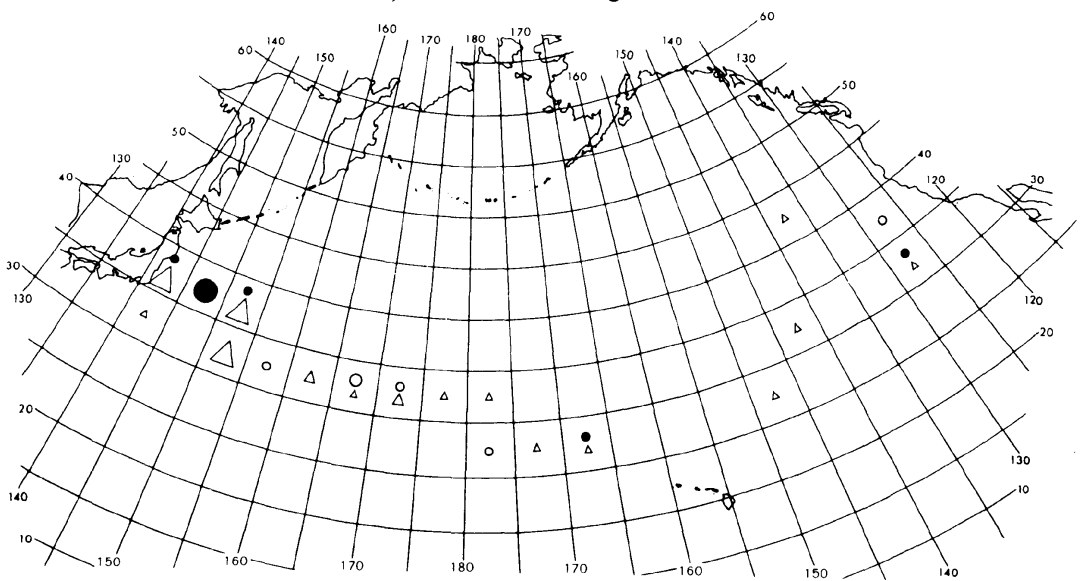

5) Pterodroma nigripennis

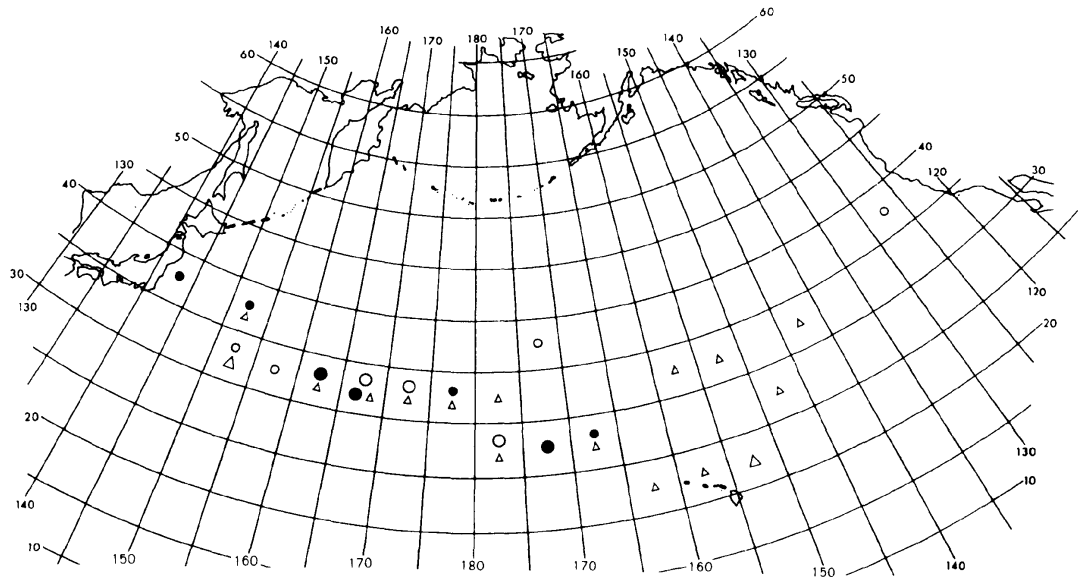


6) Pterodroma cooki

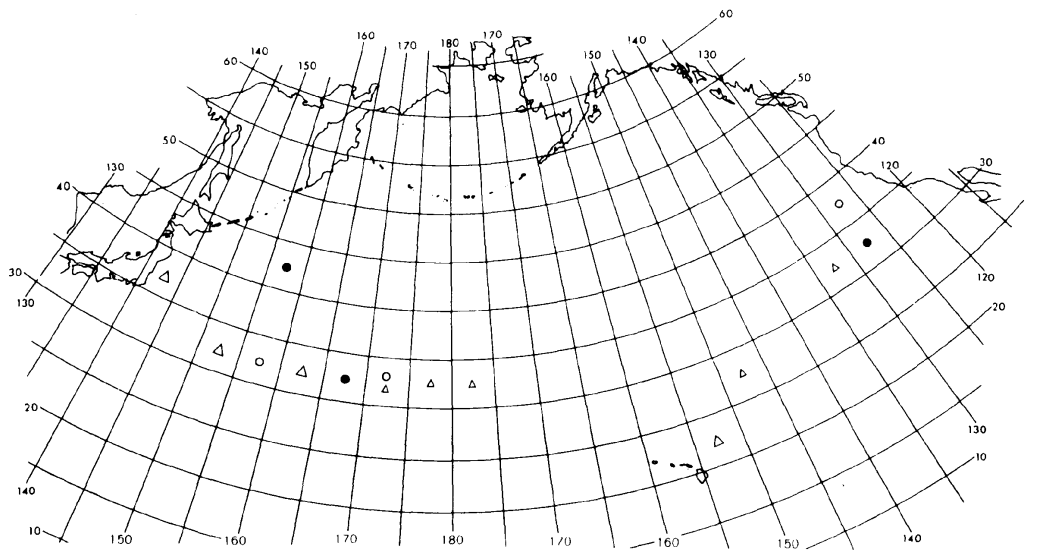

7) Pterodroma pycrofti

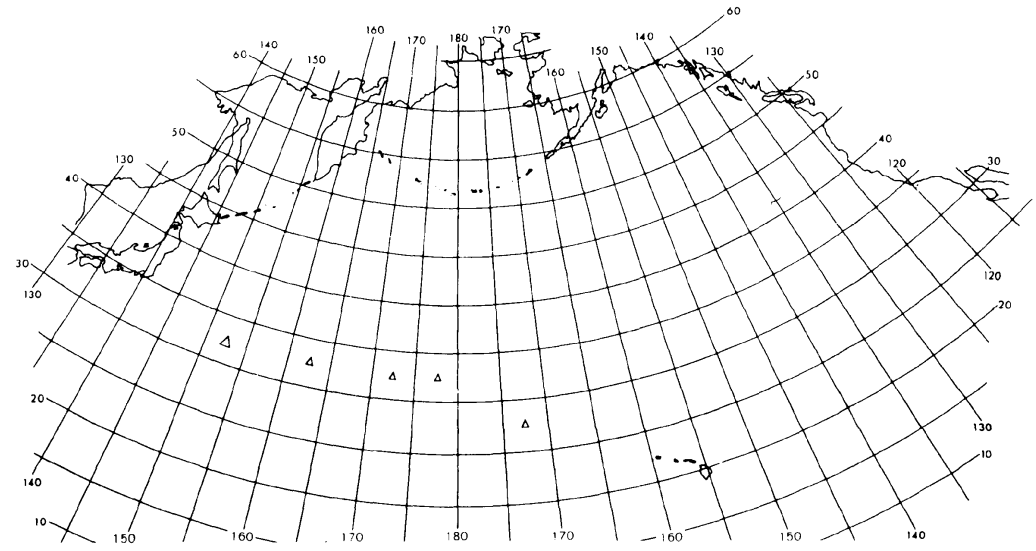

b-2. North to temperate zone

1) Pterodroma solandri

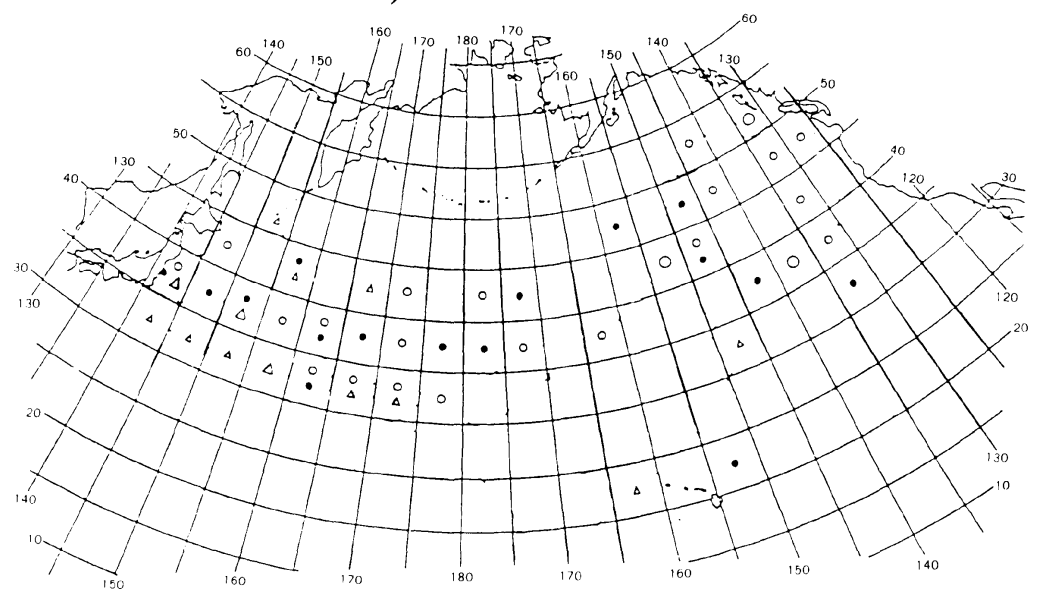


Procellariiformes in the North Pacific

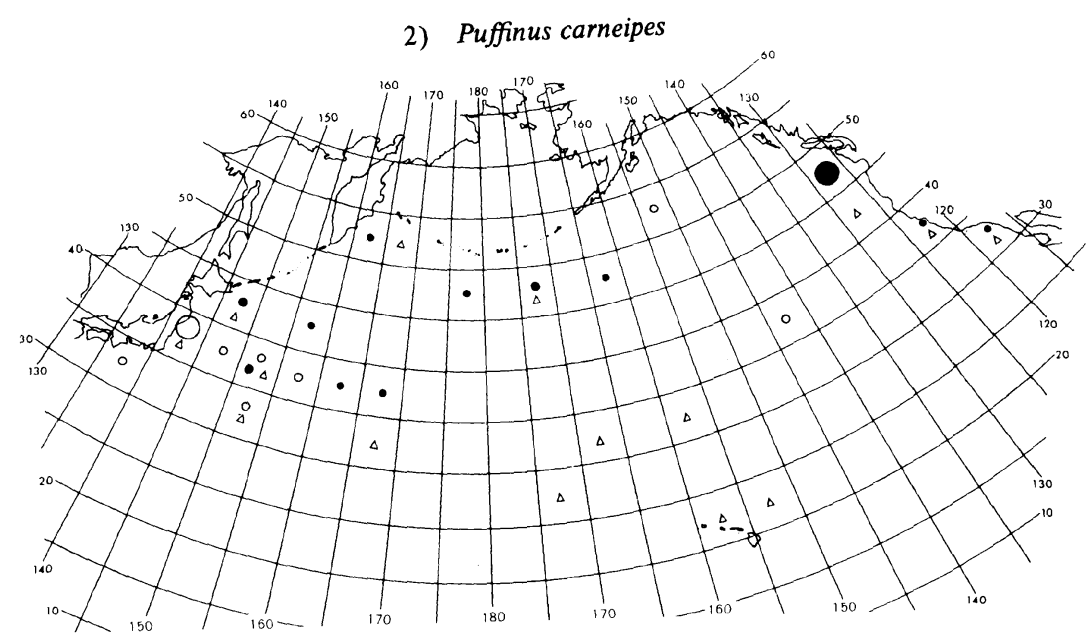

3) Puffinus bulleri

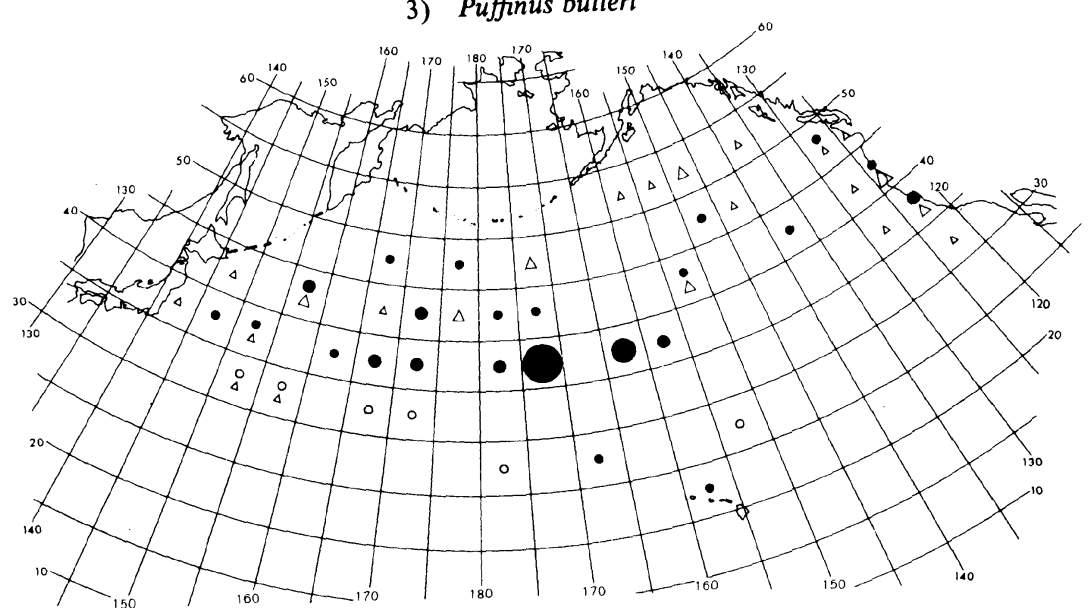

4) Puffinus griseus

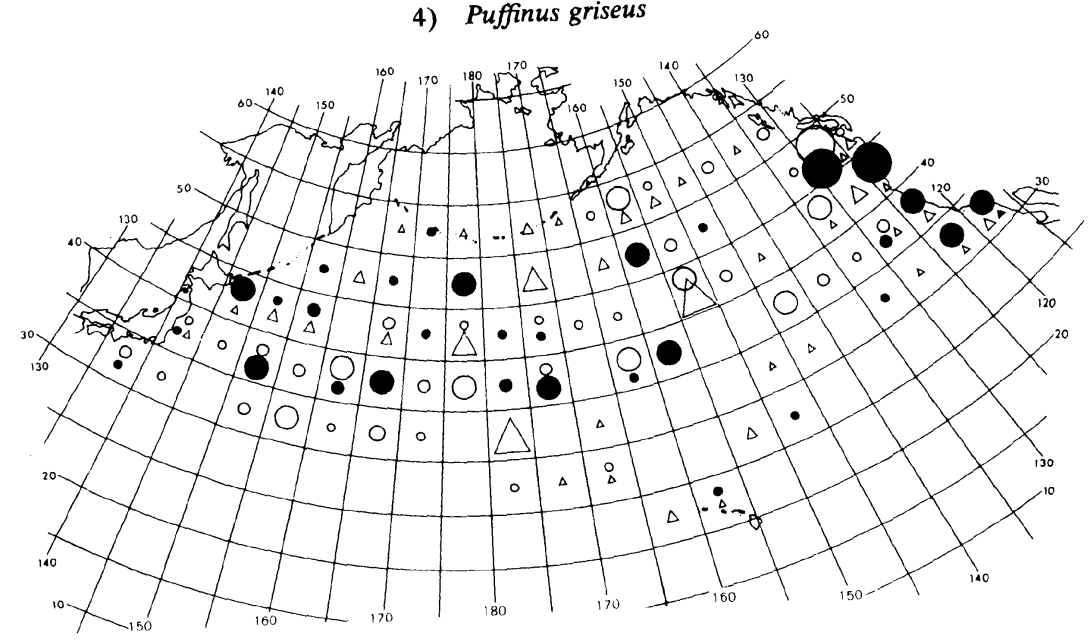


b-3. North into Bering Sea

1) Puffinus tenuirostris

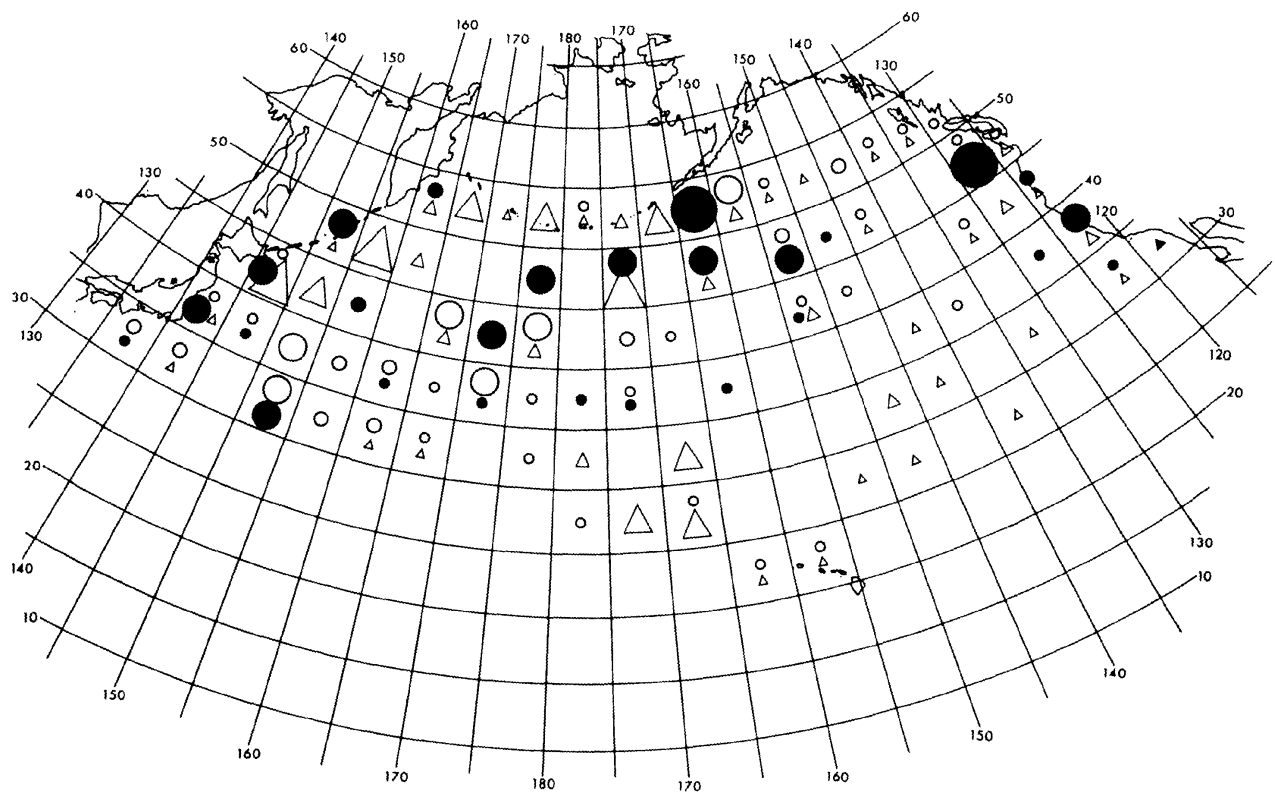

2) Pterodroma inexpectata

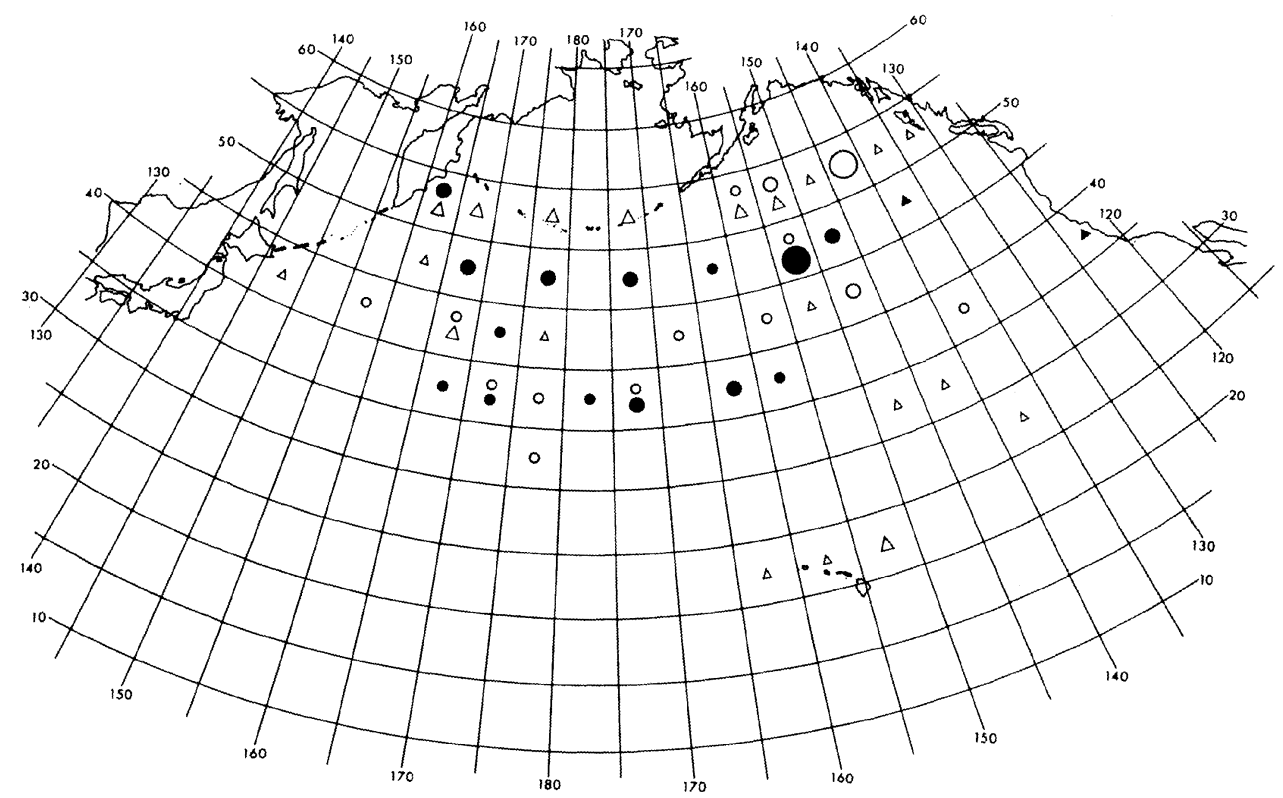


Appendix II. Seasonal movements of some southerm hemisphere migrants.
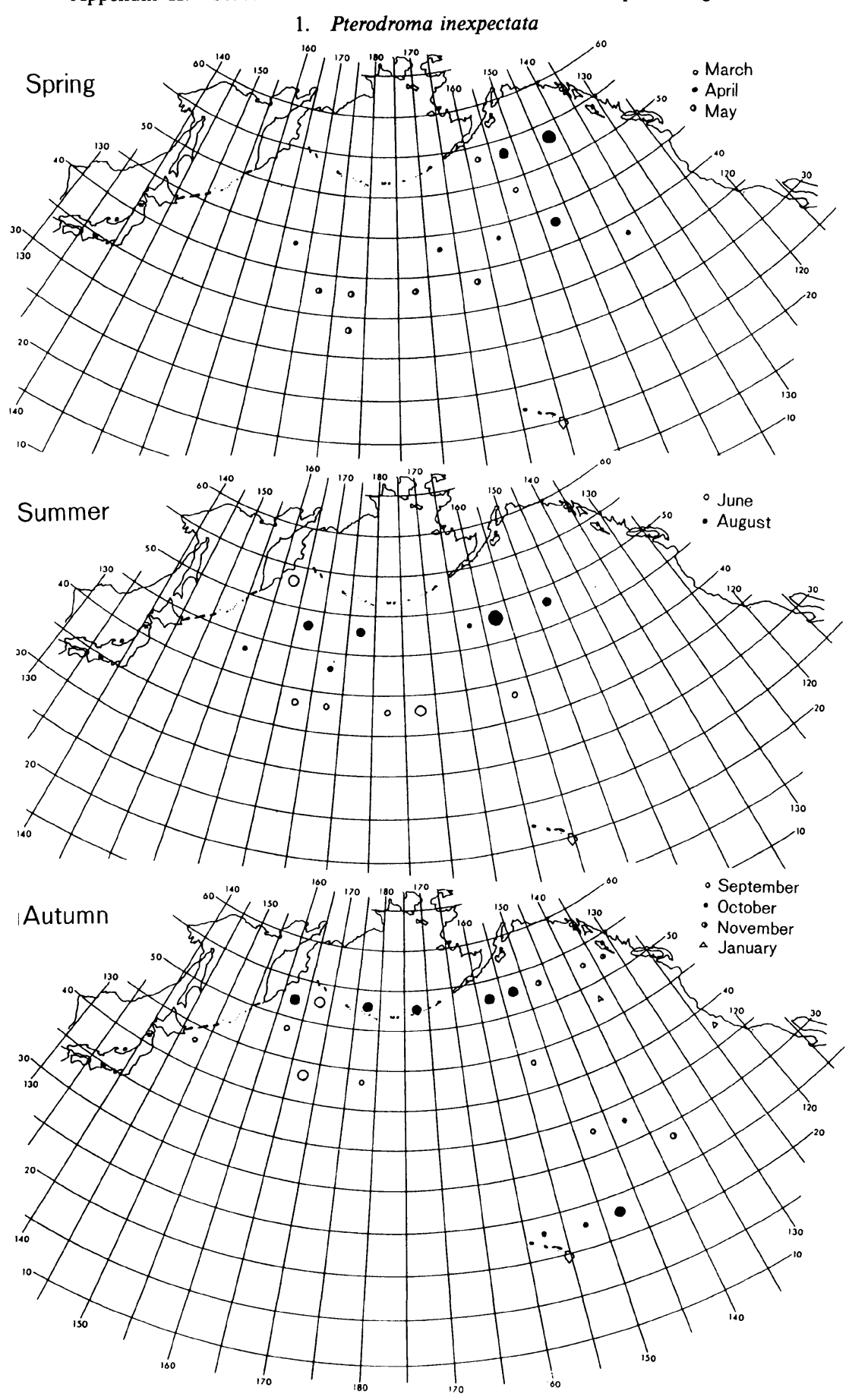


\section{Pterodroma solandri}

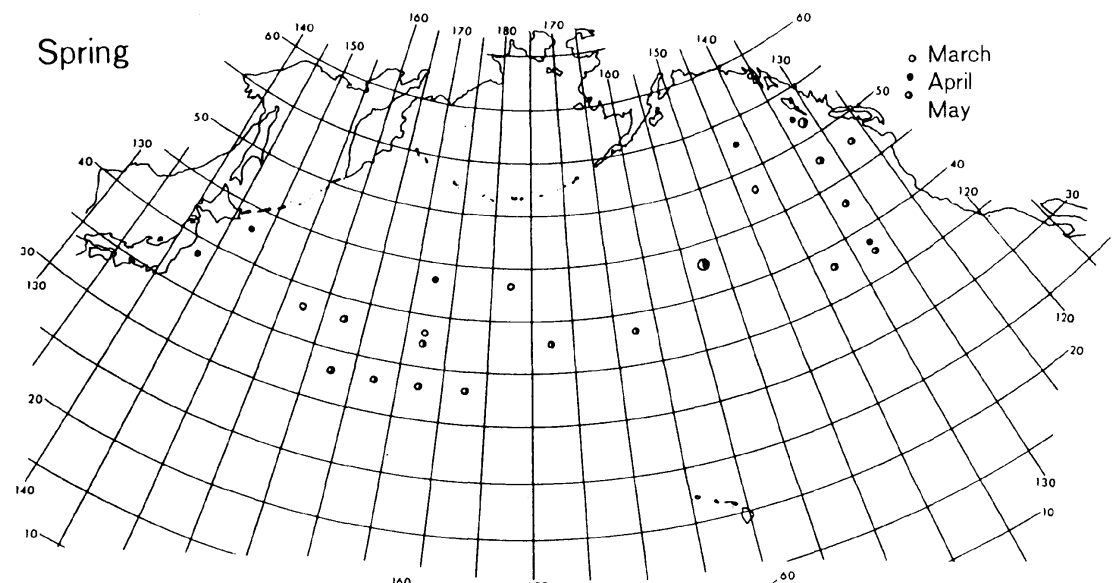

Summer August
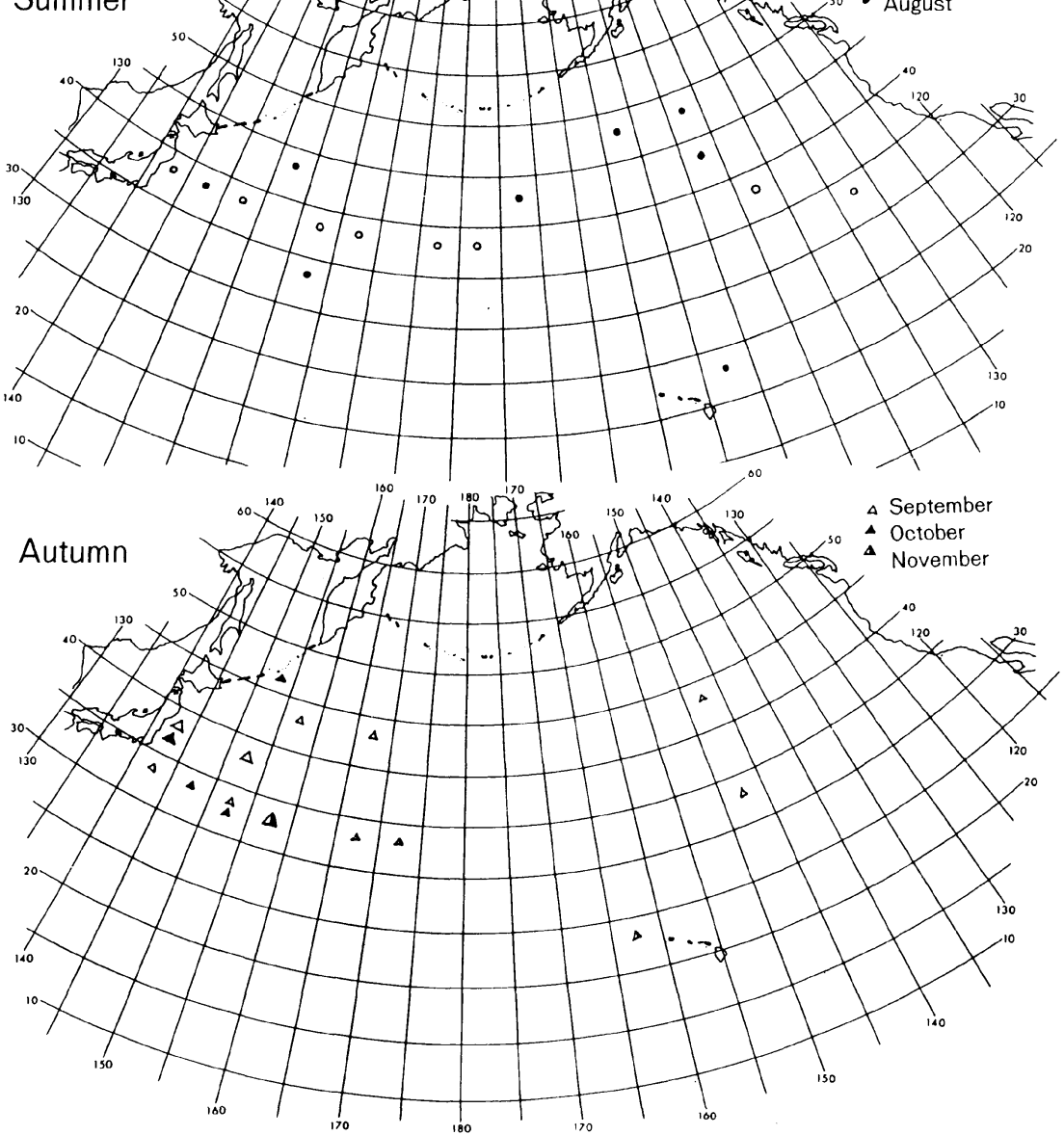


\section{Puffinus carneipes}
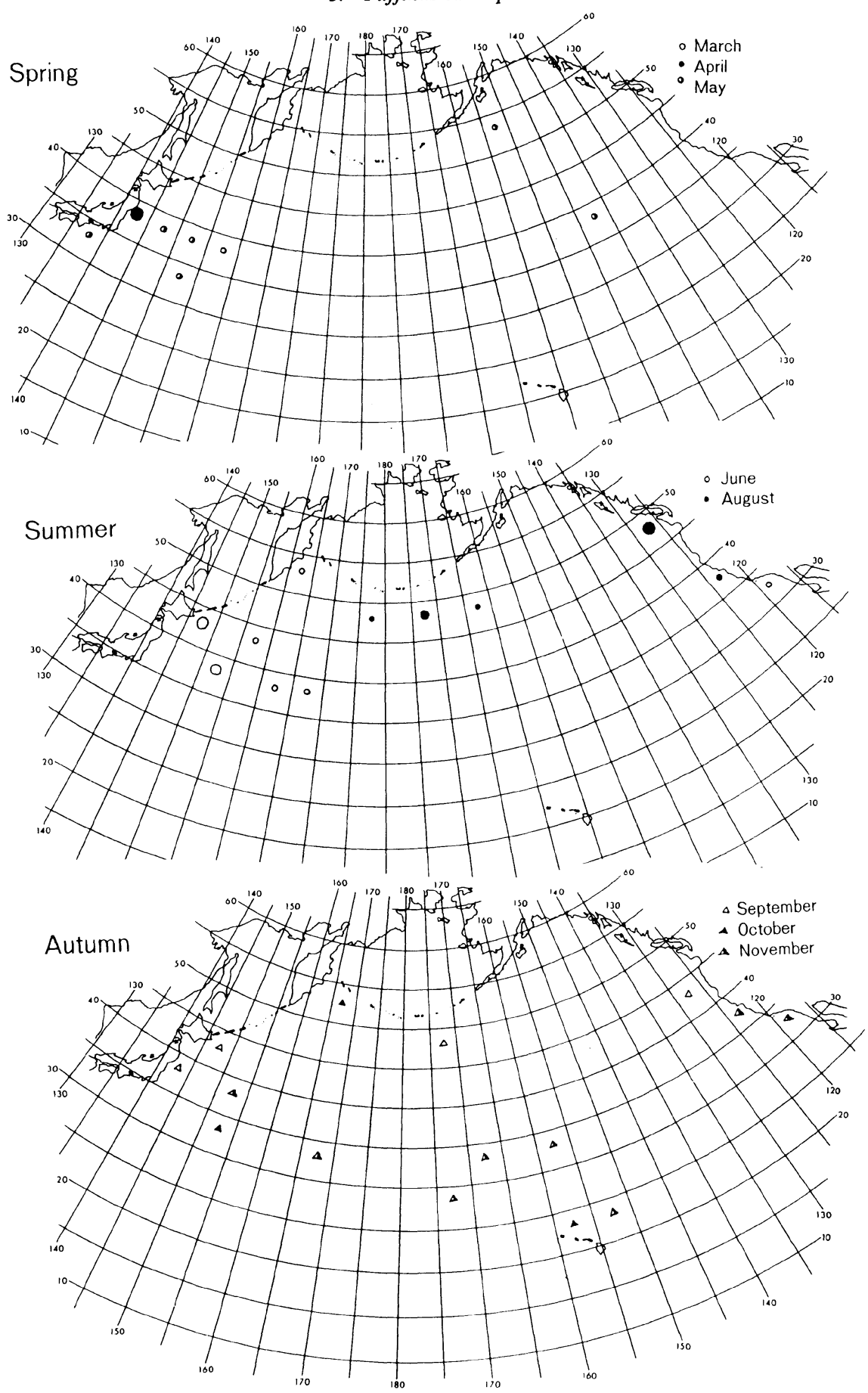


\section{Puffinus bulleri}
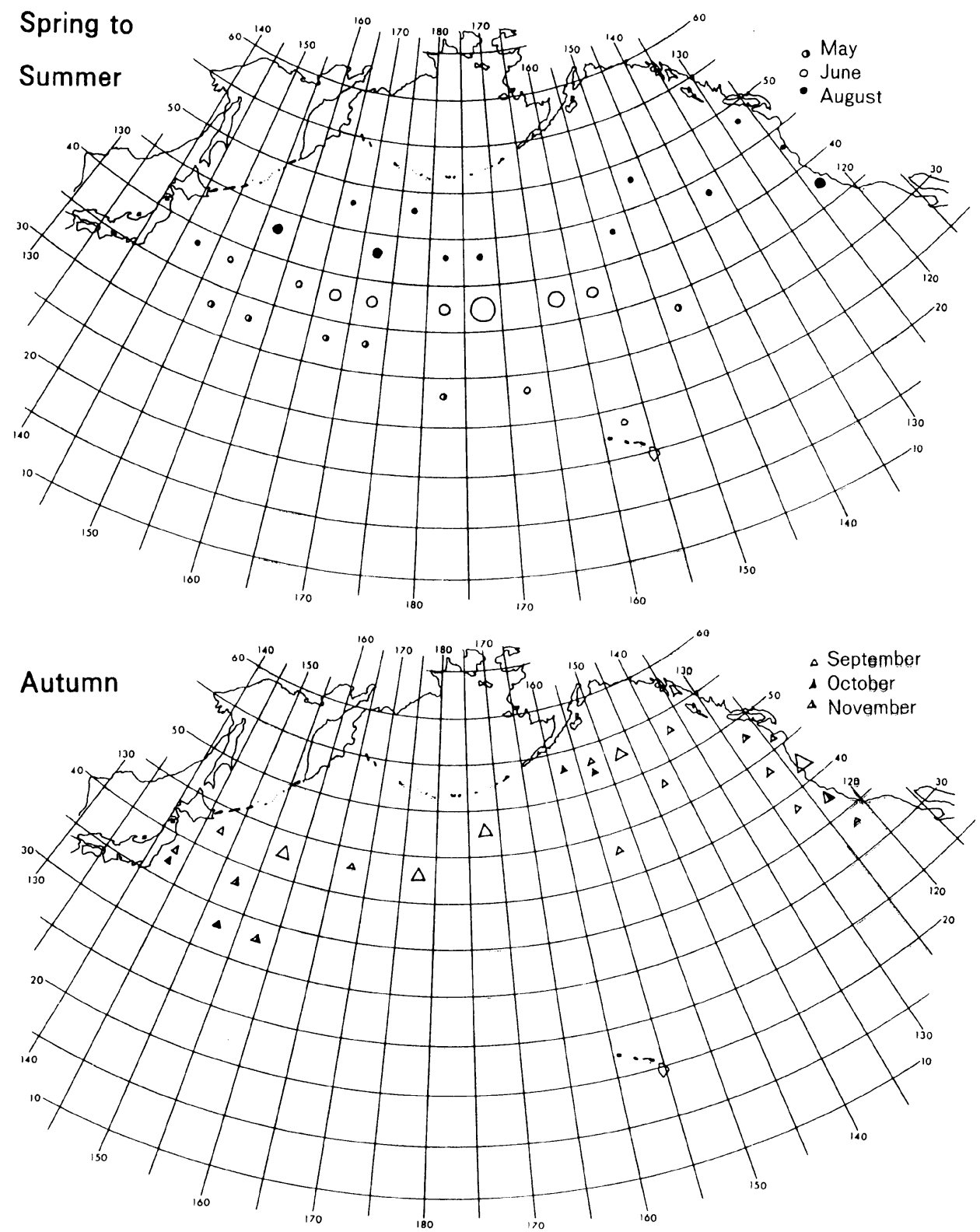


\section{Puffinus griseus}
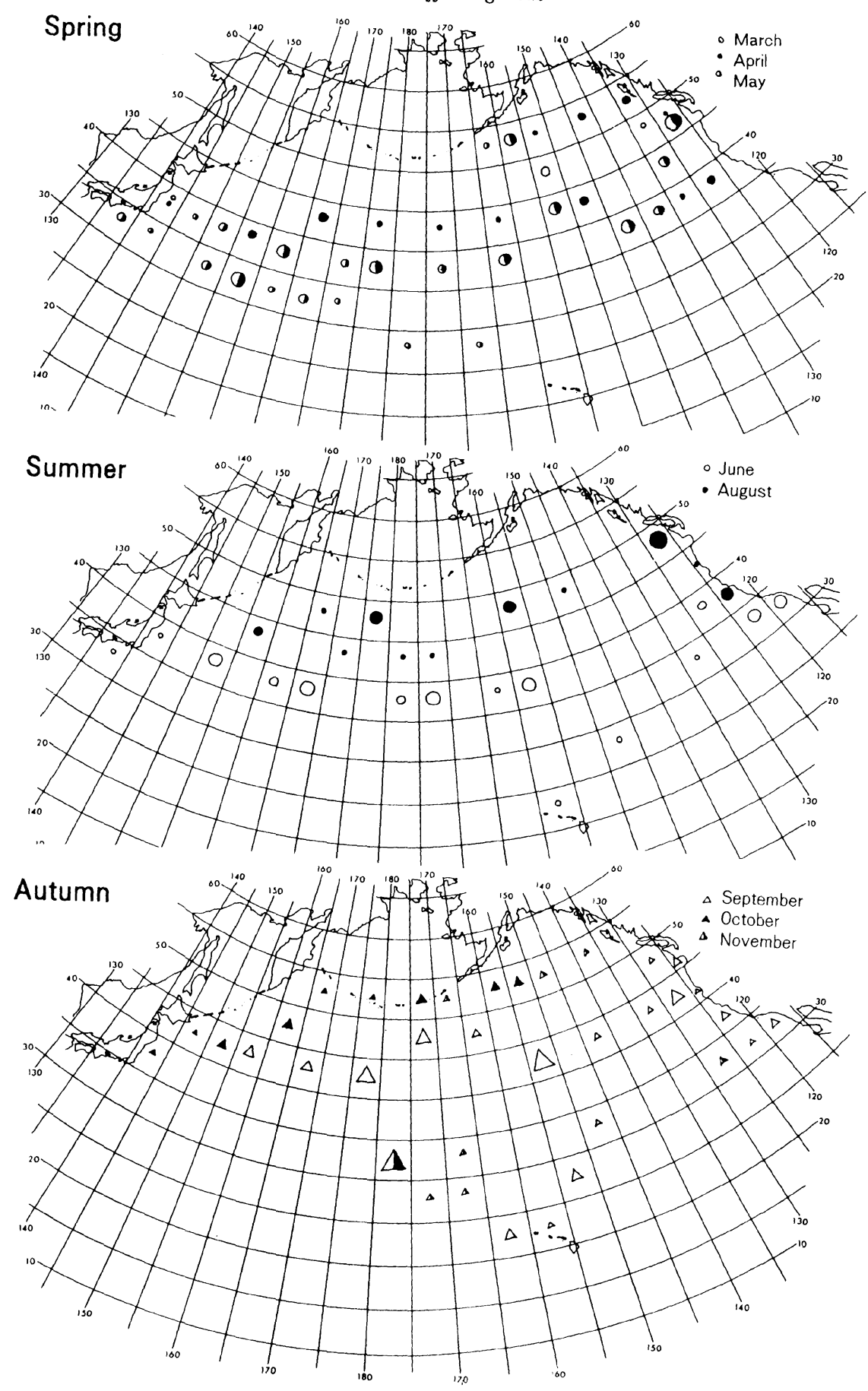
Appendix III. Seasonal records of water temperature for Procellariiformes in the North Pacific during 1983-85.

Note: Figures indicate the number of birds recorded per hour. "15.5/3" means an average No./hour of three records.

1. Boreal to temperate dispersal pattern

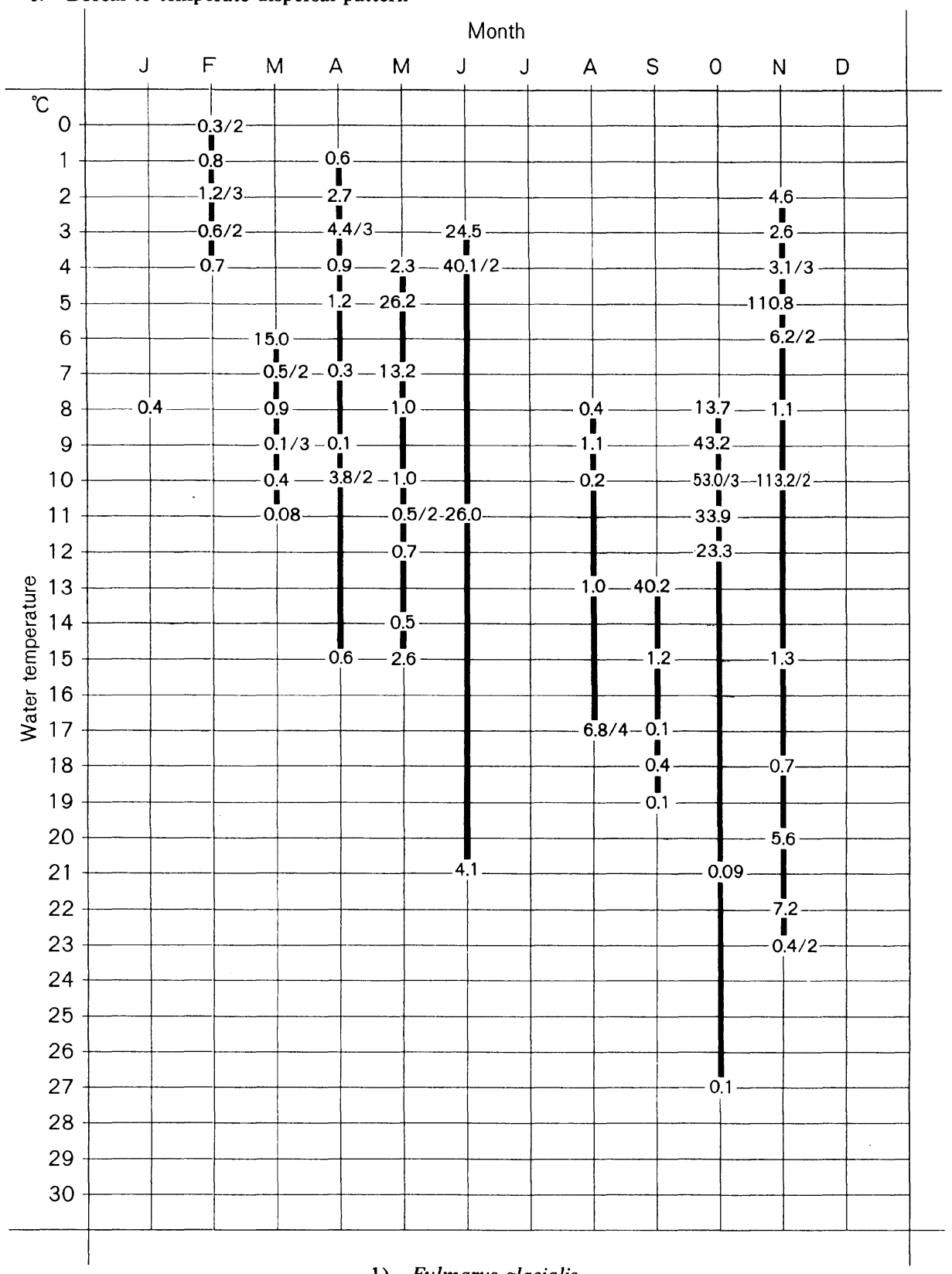

1) Fulmarus glacialis 


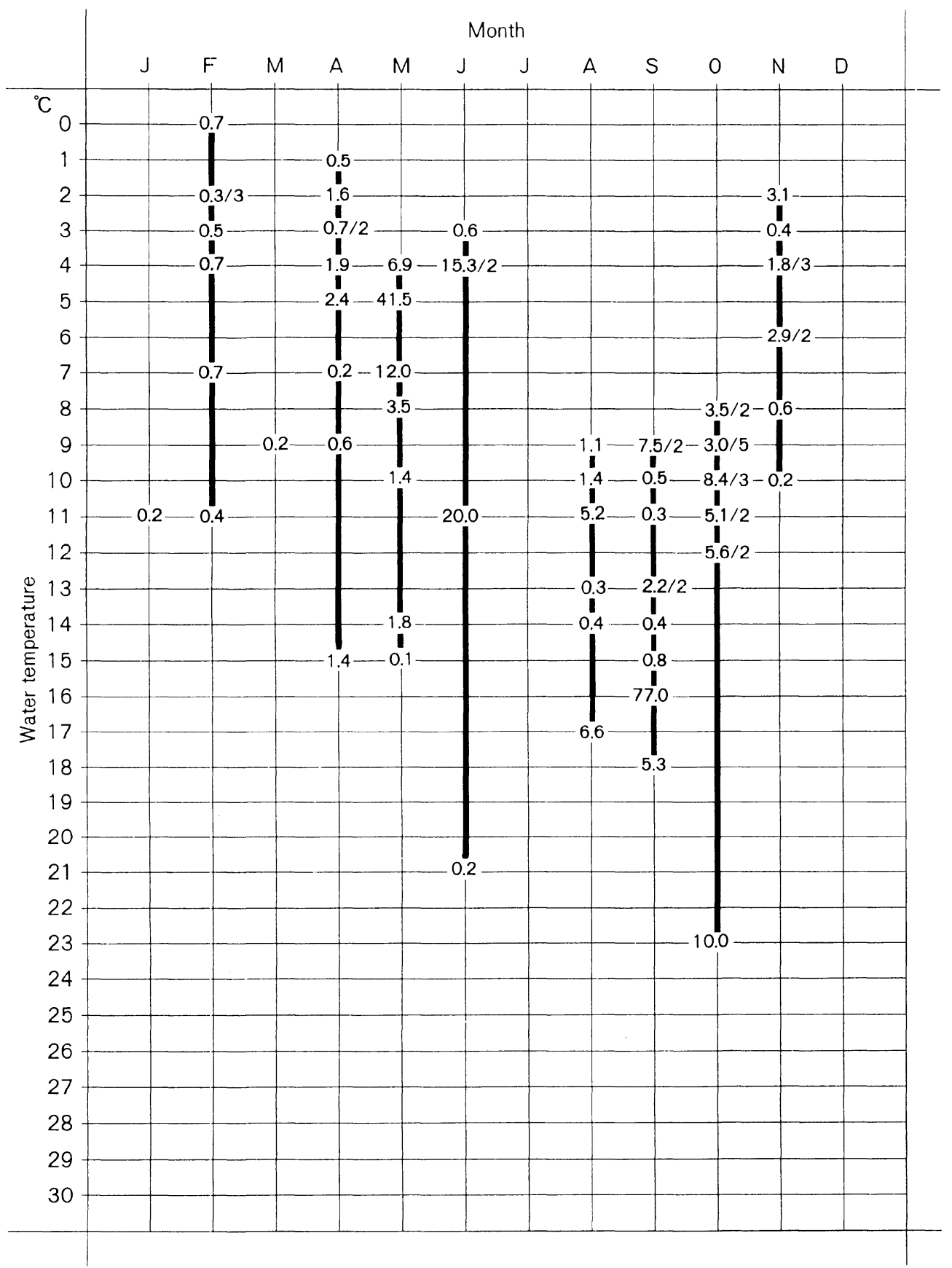

2) Oceanodroma furcata 
2. Temperate to subtropical dispersal patterns

a. Northern hemisphere breeders

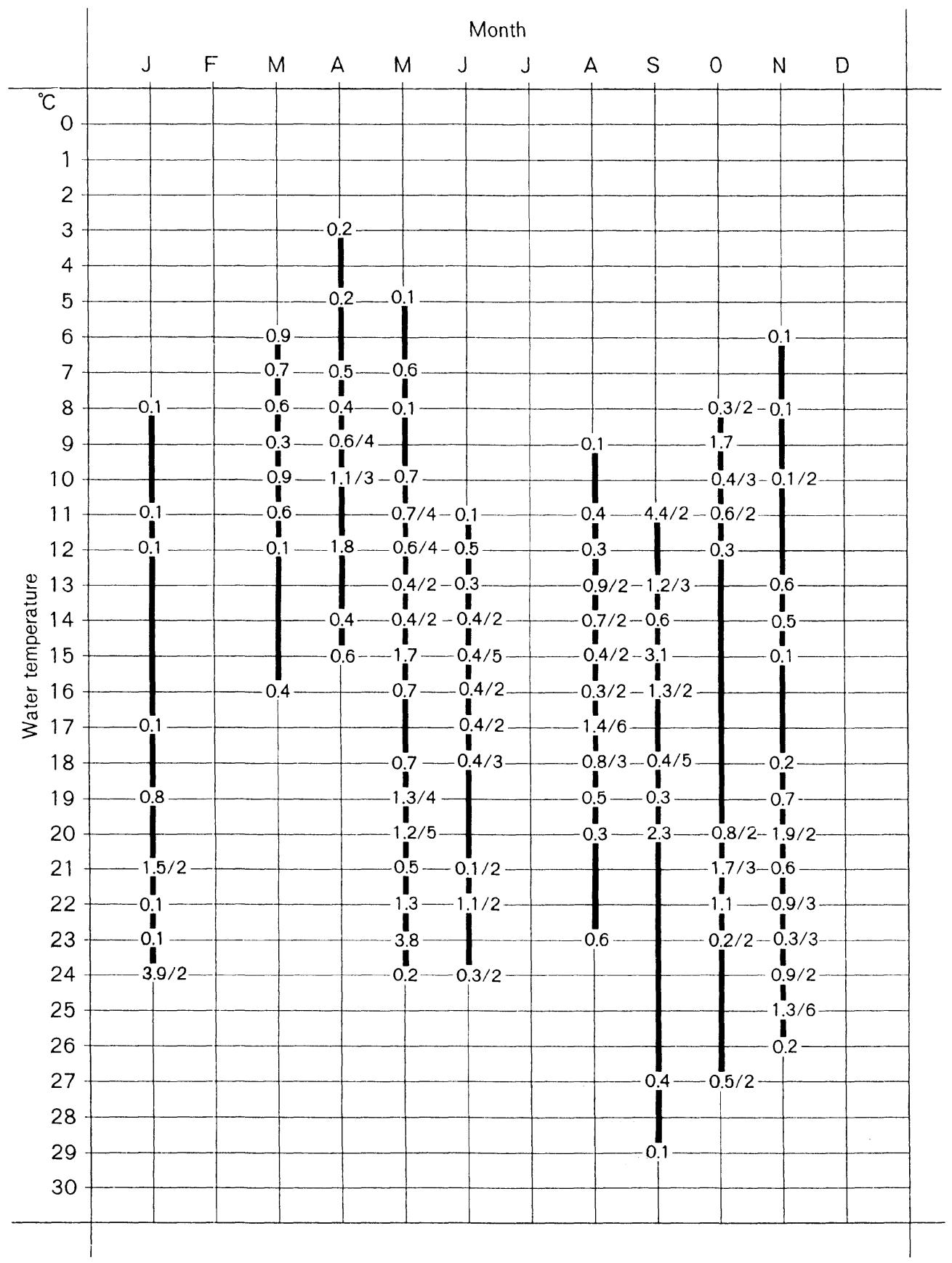

1) Diomedea nigripes 


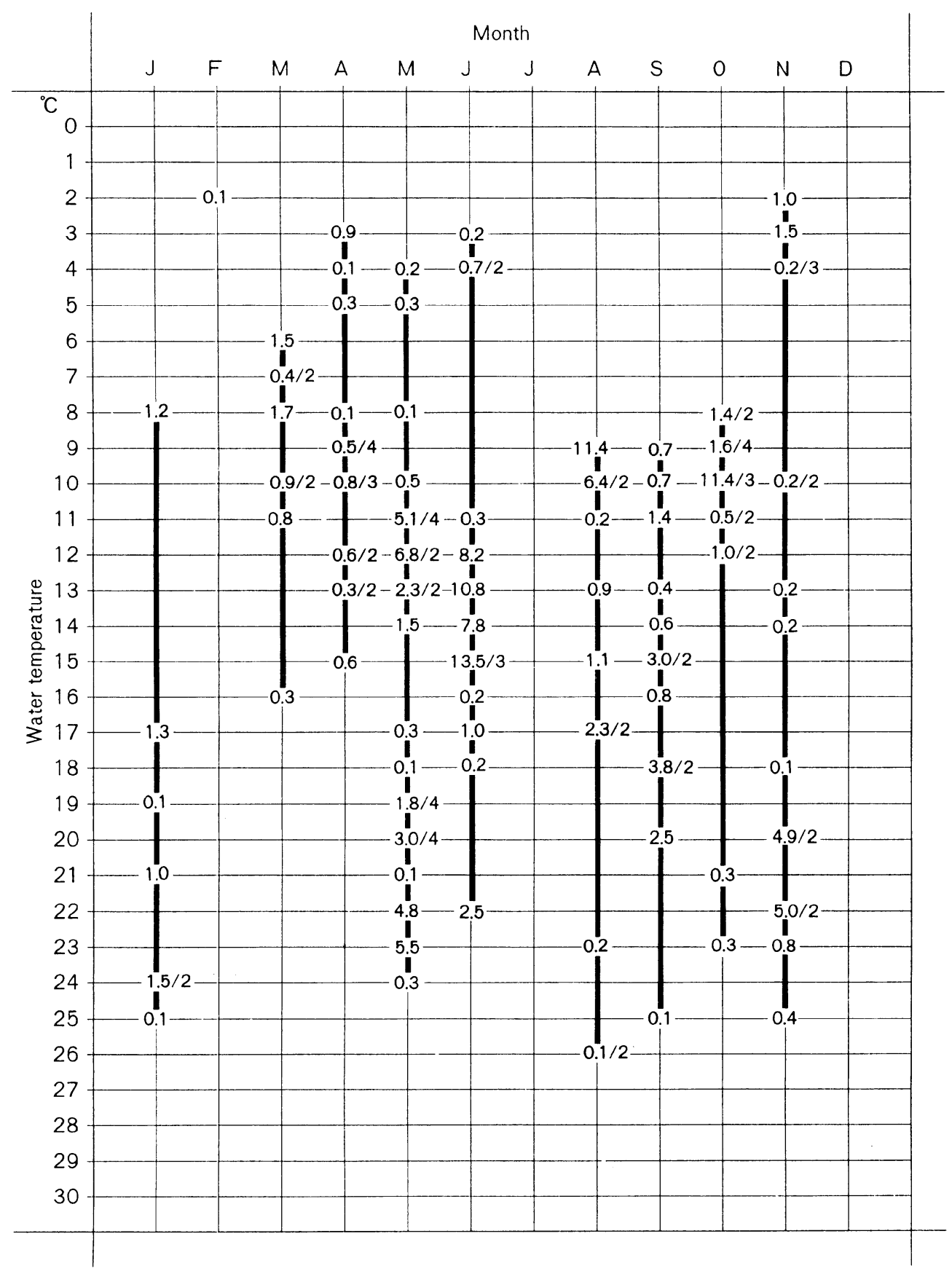

2) Diomedea immutabilis 


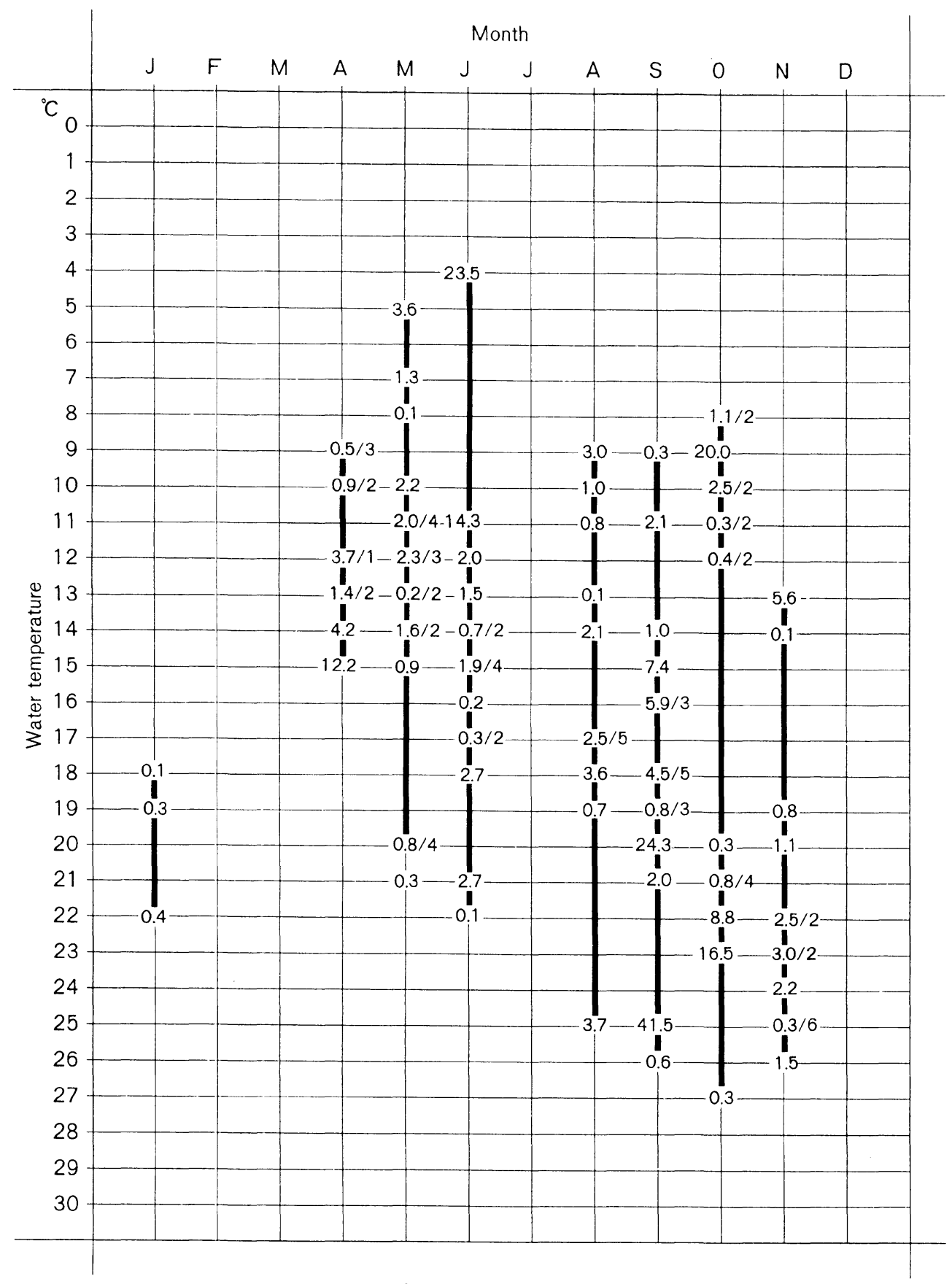

3) Oceanodroma leucorhoa 
3. Coastal patterns

a. Japanese side

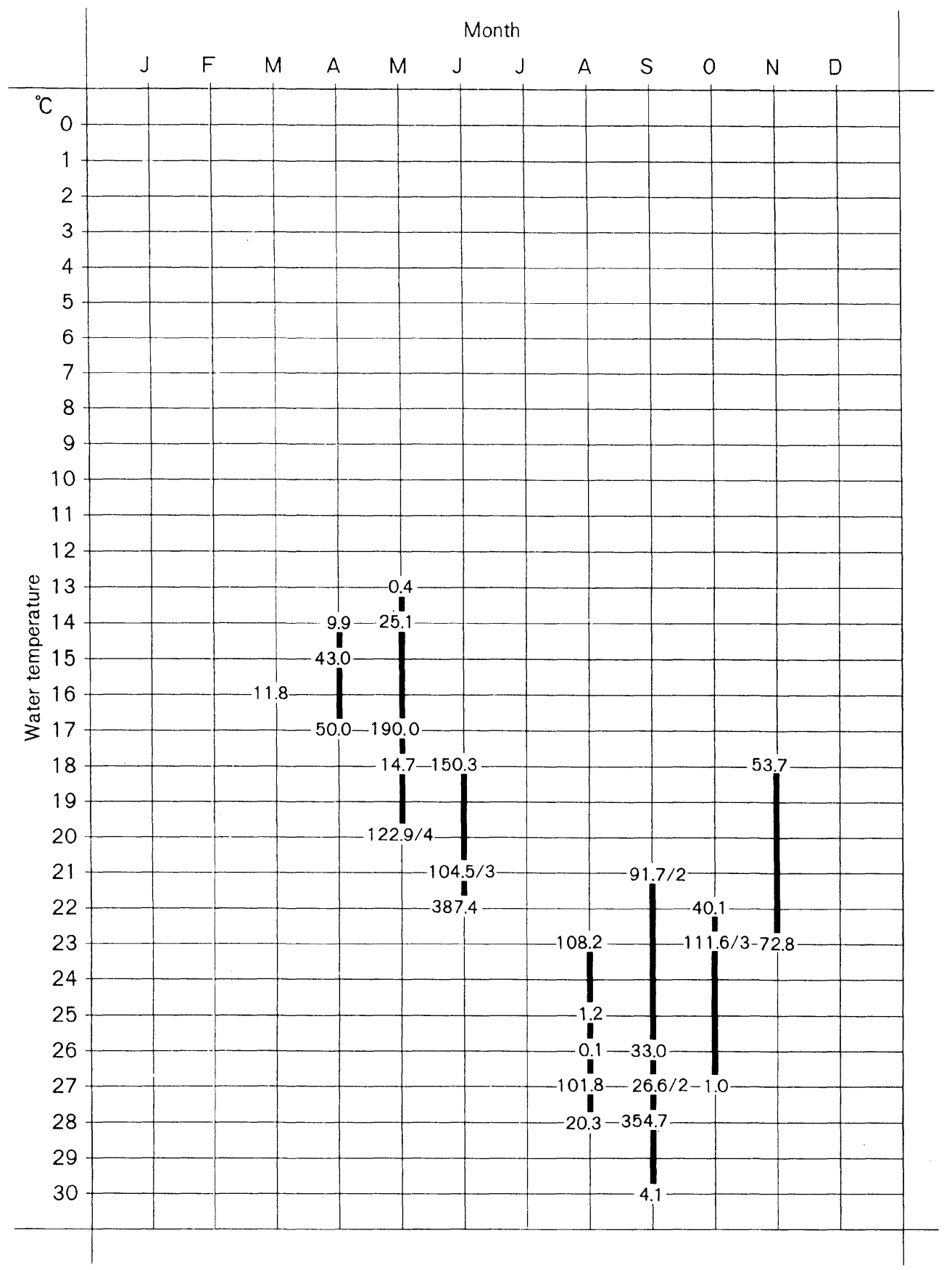

1) Calonectris leucomelas 


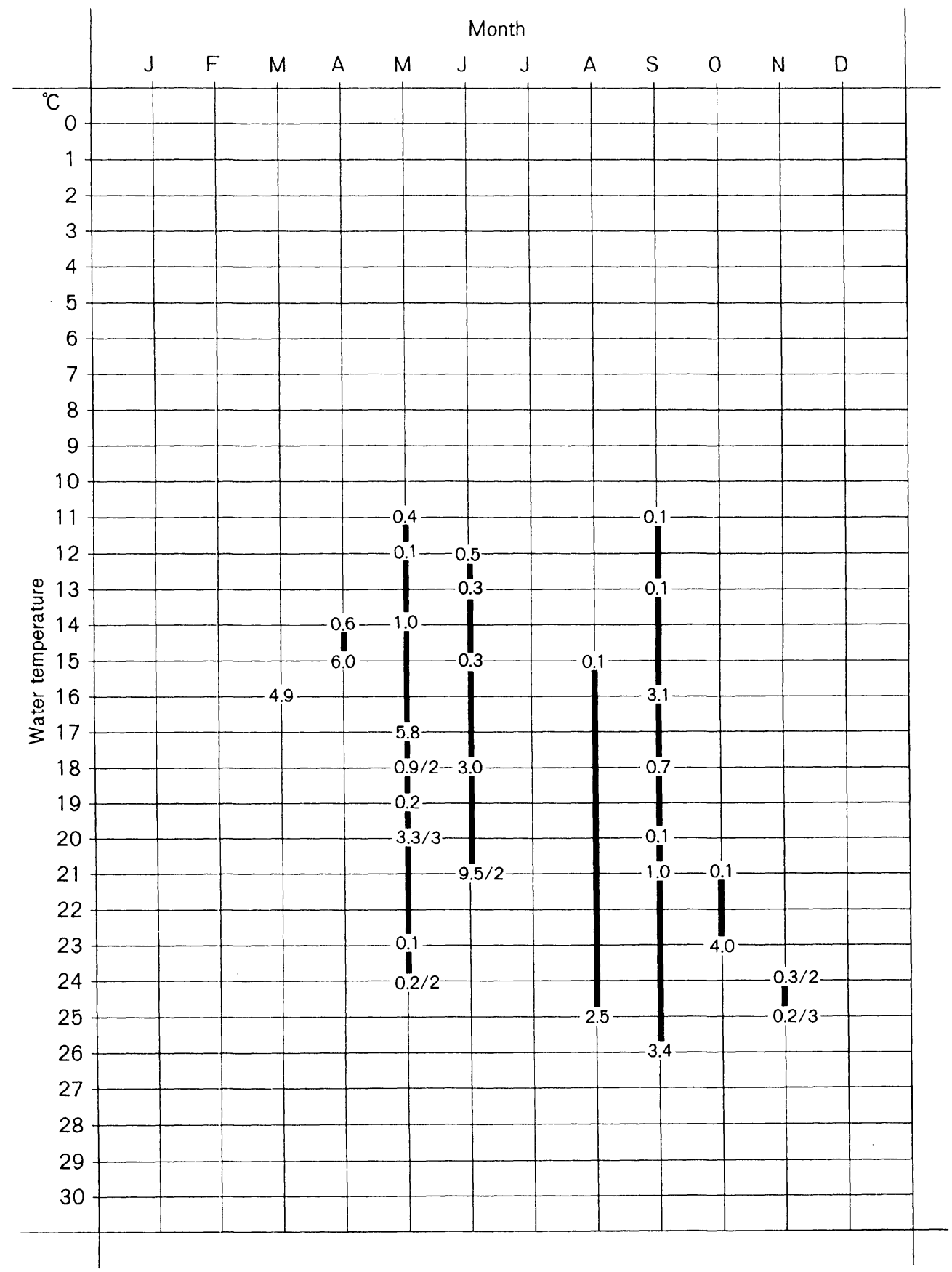

2) Oceanodroma tristrami 


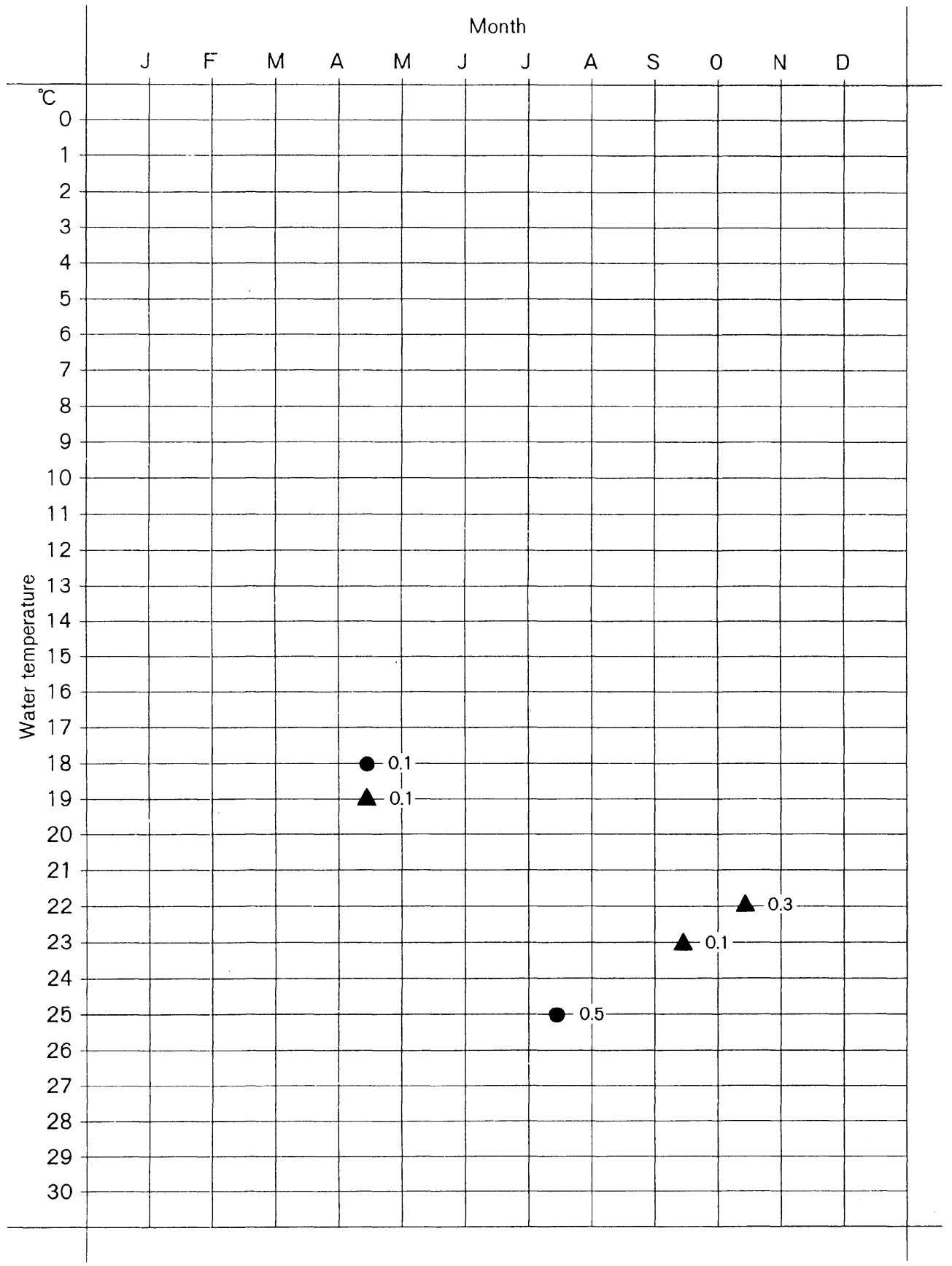

3) Oceanodroma matsudairae

4) Oceanodroma monorhis 


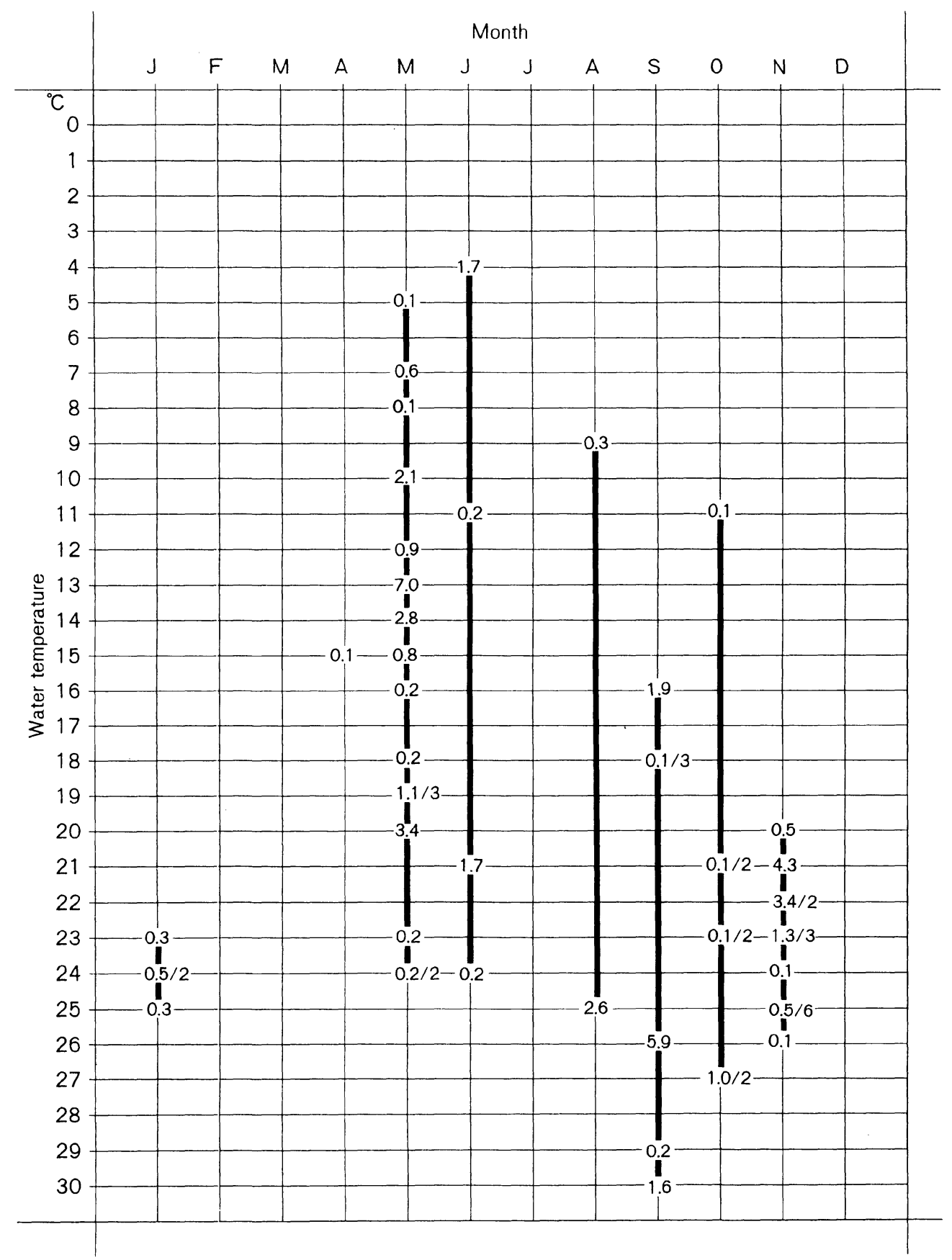

5) Oceanodroma castro 


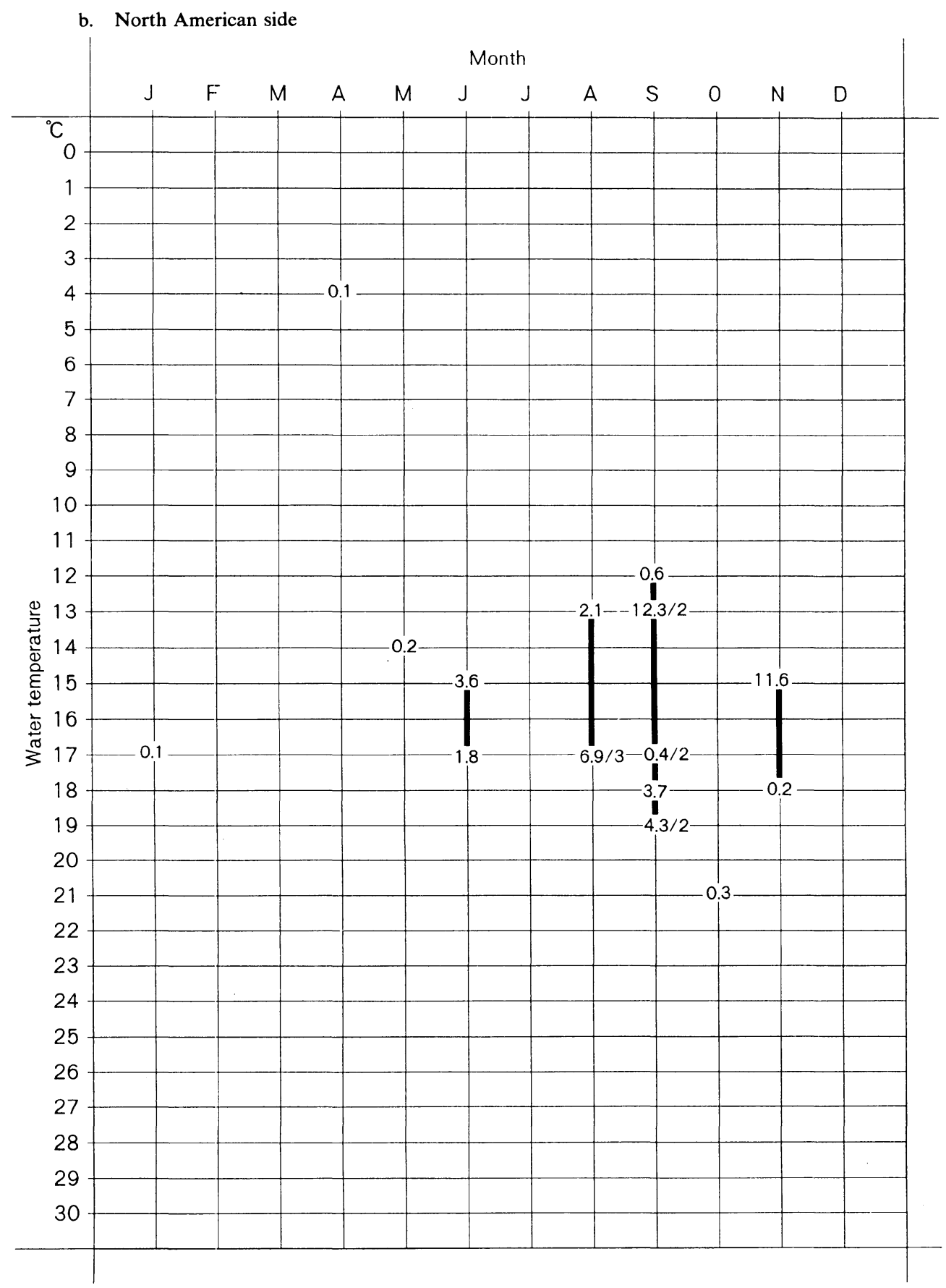

1) Puffinus creatopus 


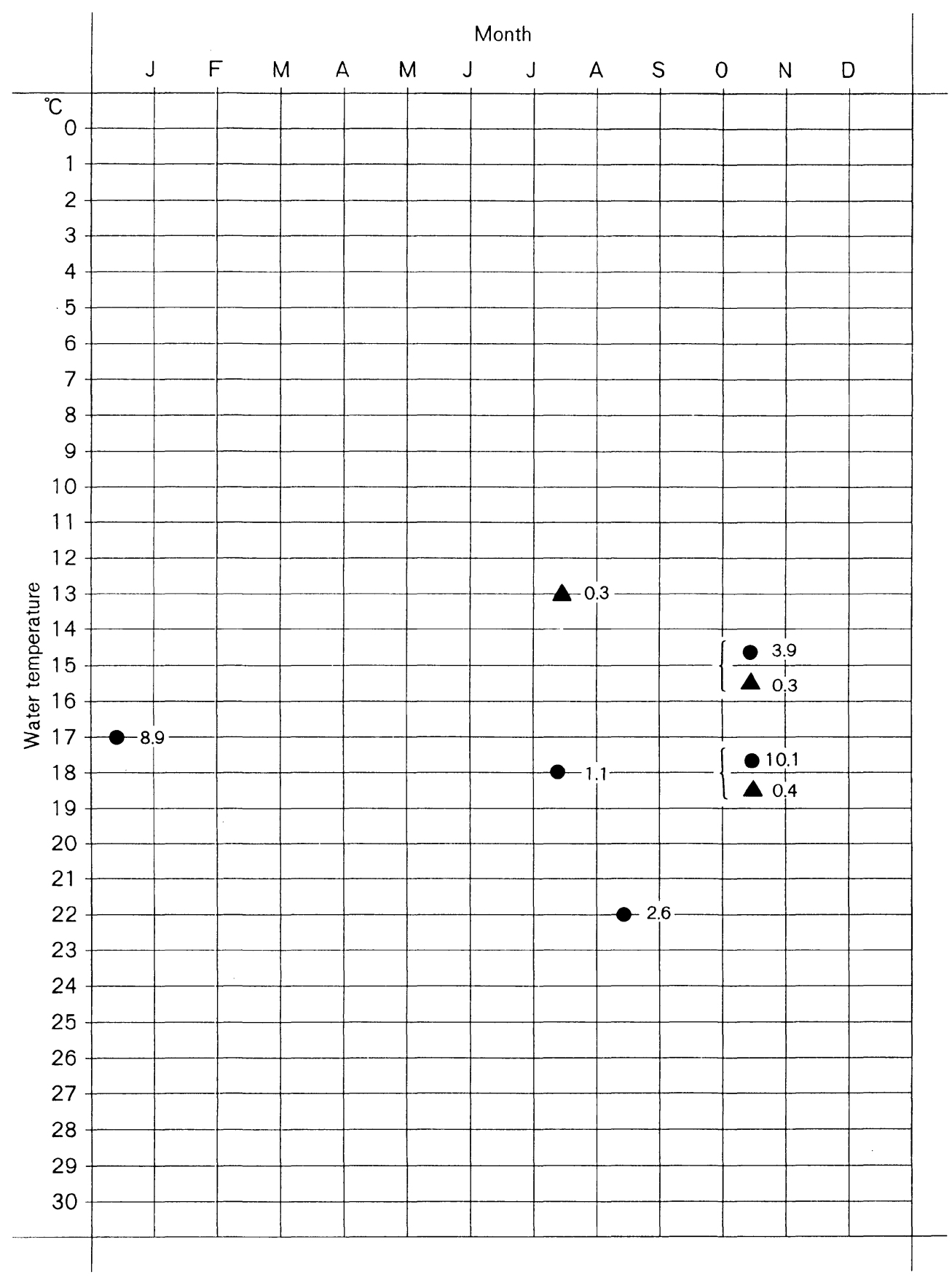

2) Puffinus opisthomelas

3) Puffinus auricularis $\Delta$ 


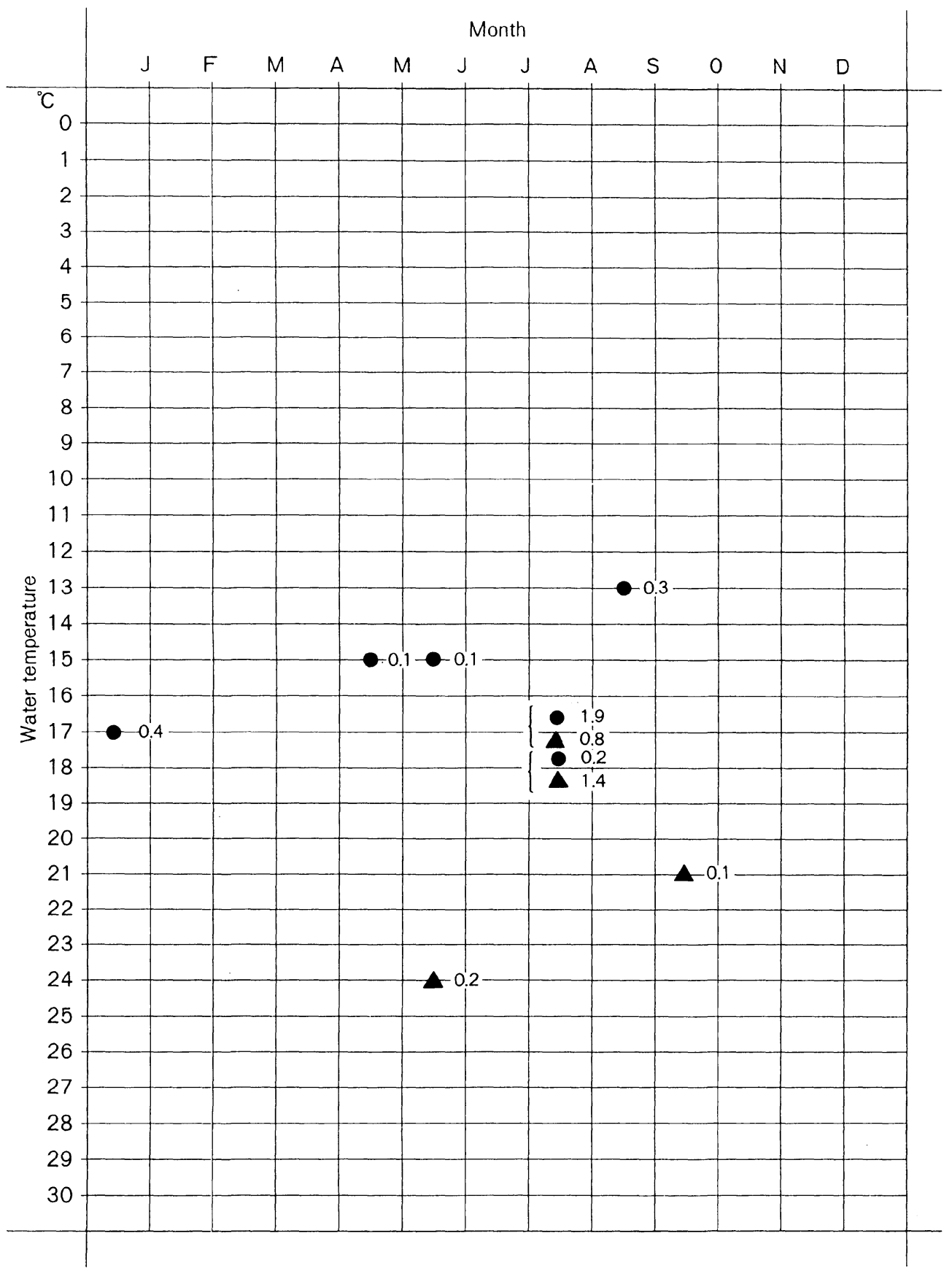

4) Oceanodroma melania

5) Oceanodroma homochroa $\Delta$ 
4. Subtropical endemic patterns

a. Hawaiian endemic

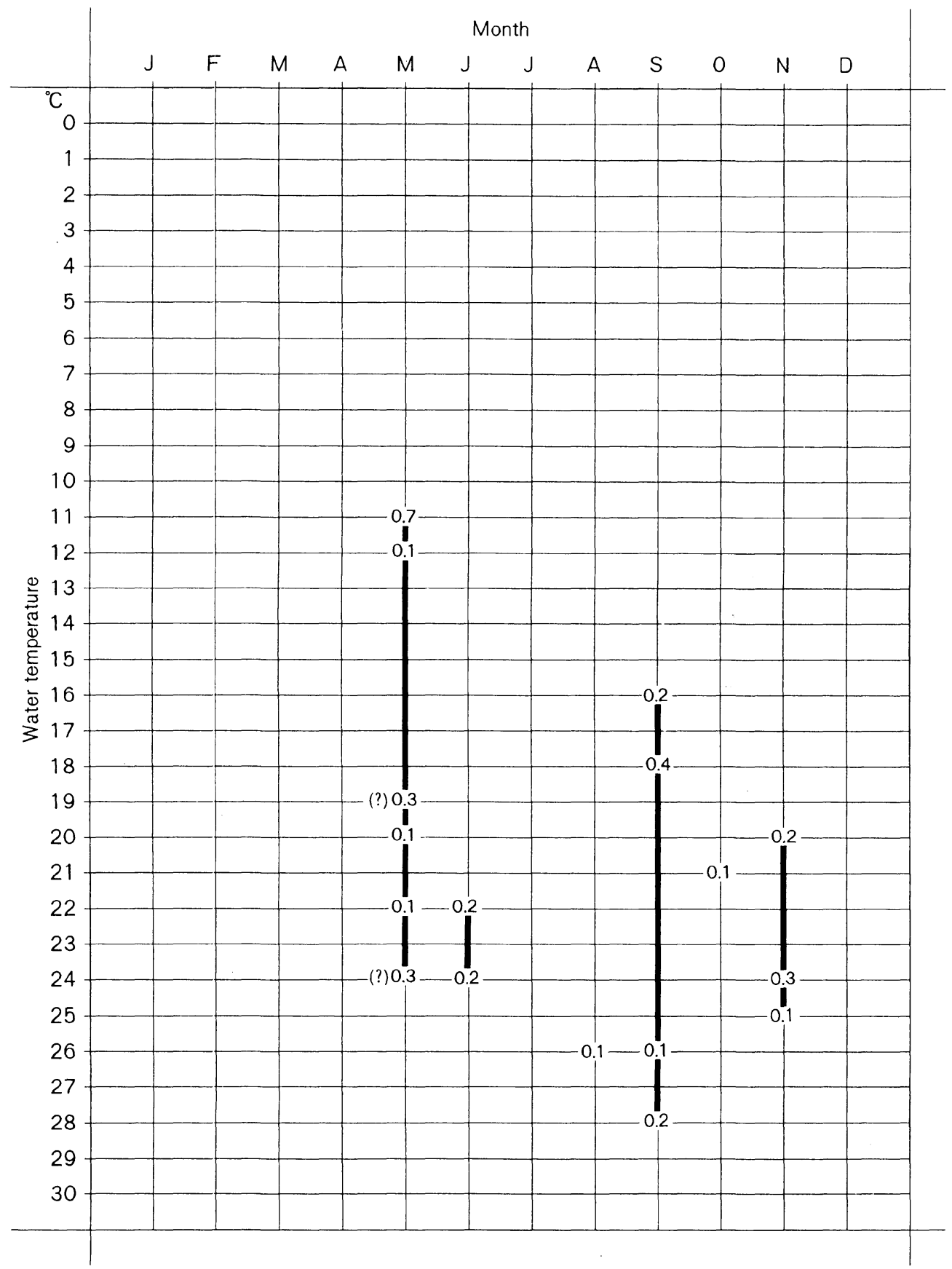

1) Pterodroma phaeopygia 
Procellariiformes in the North Pacific

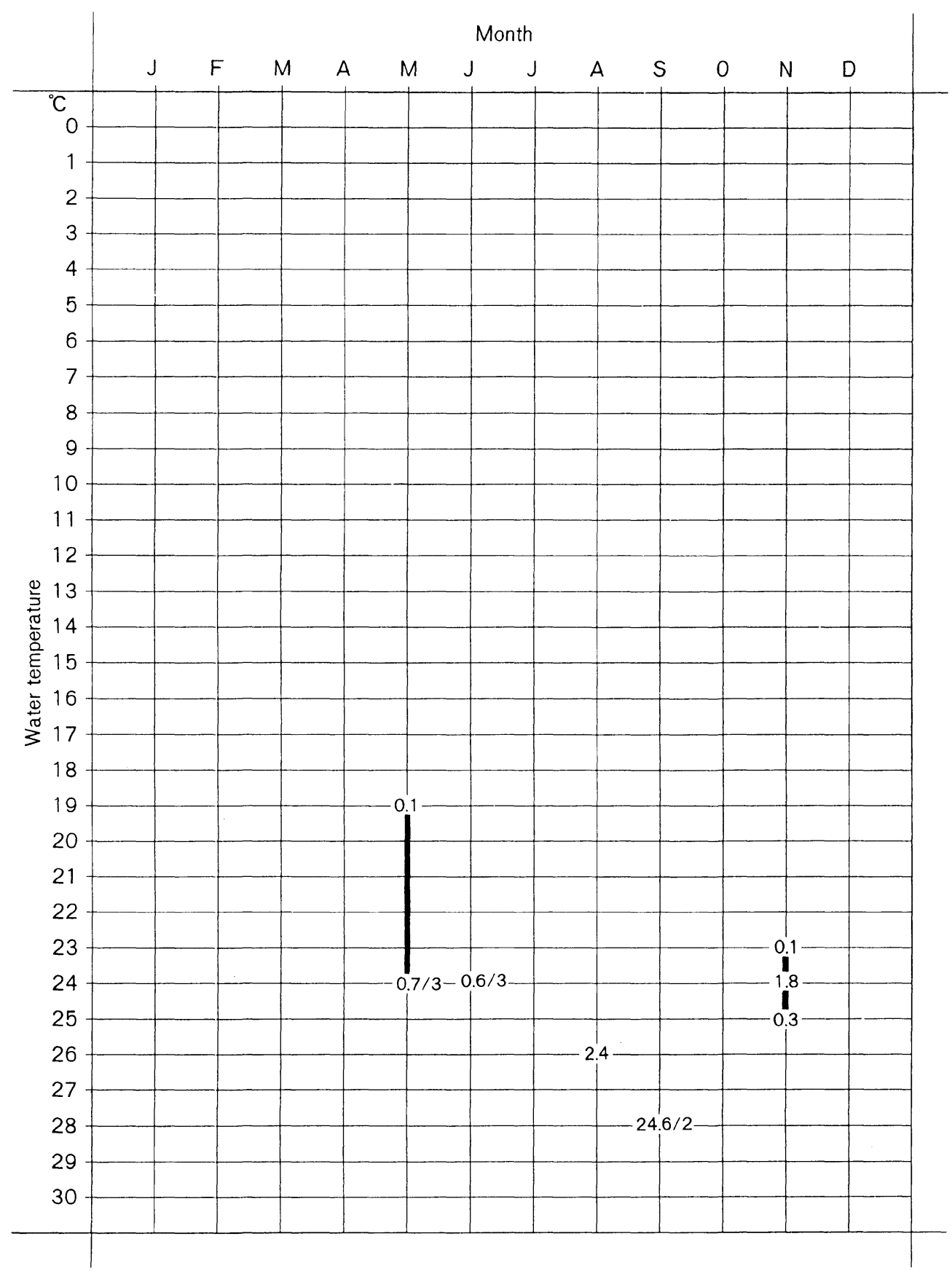

2) Puffinus newelli 
b. Subtropical endemic

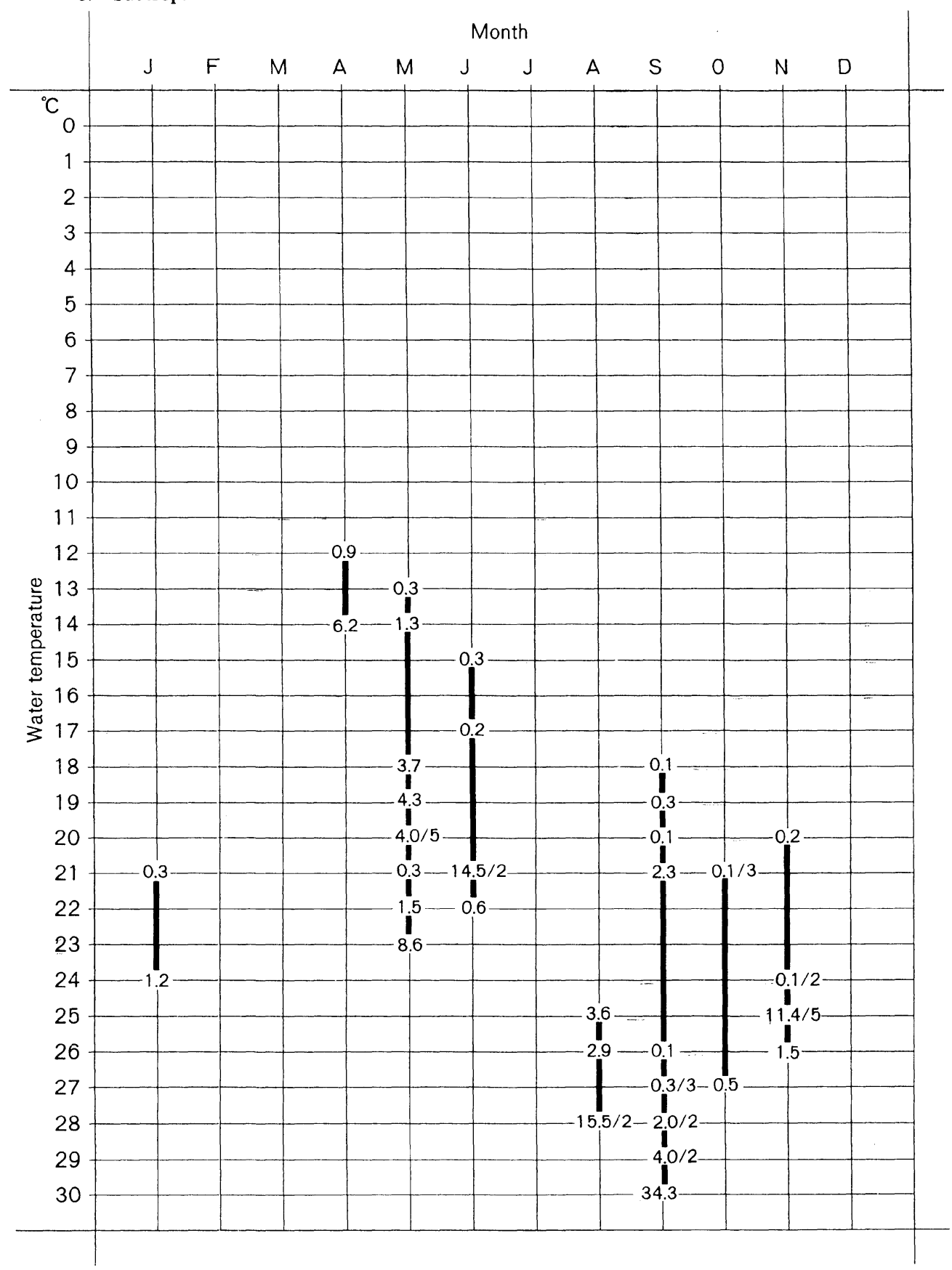

1) Pterodroma hypoleuca 
5. Subtropical to northward dispersal patterns

a. Tropical species

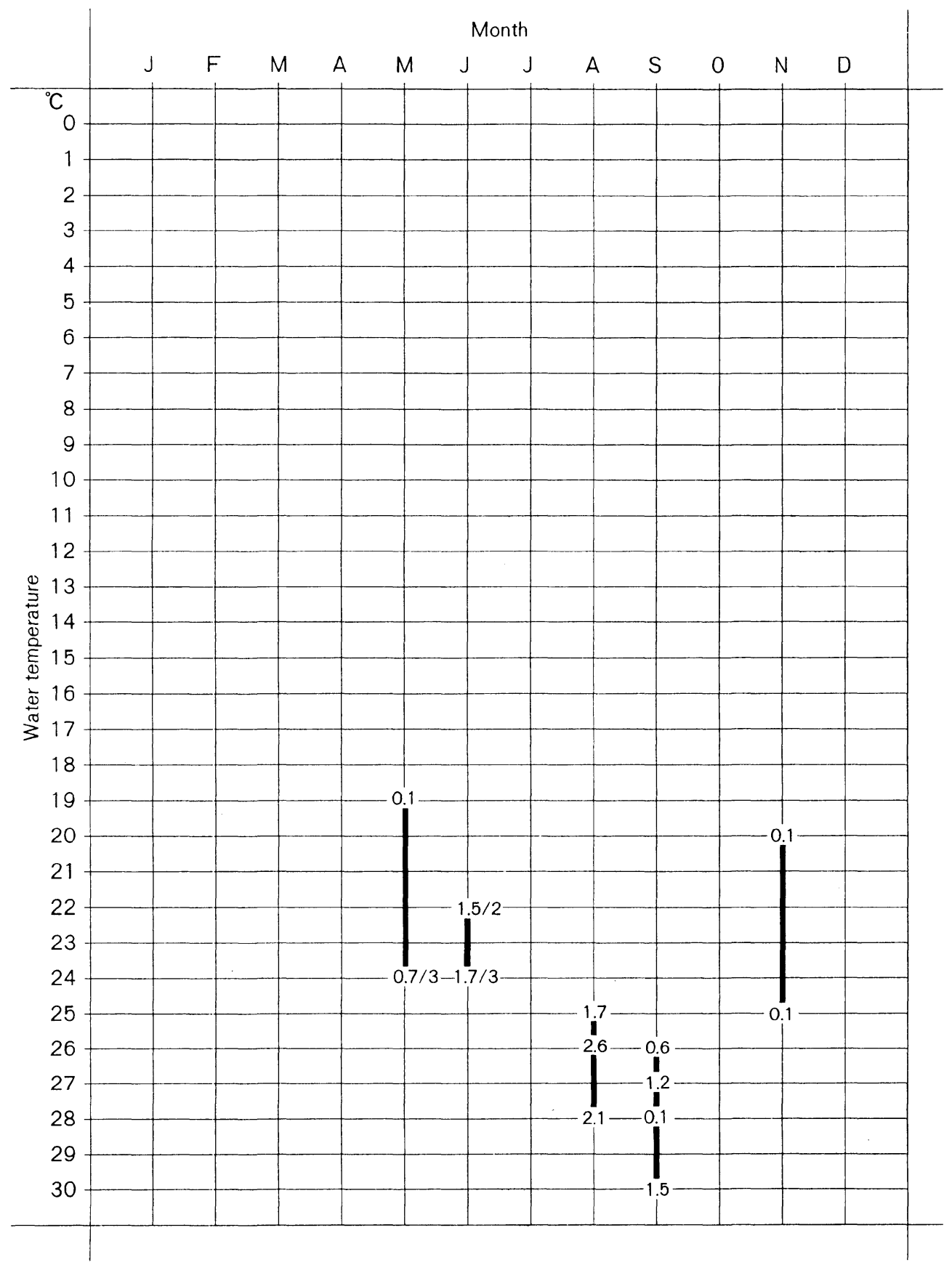

1) Bulweria bulwerii 


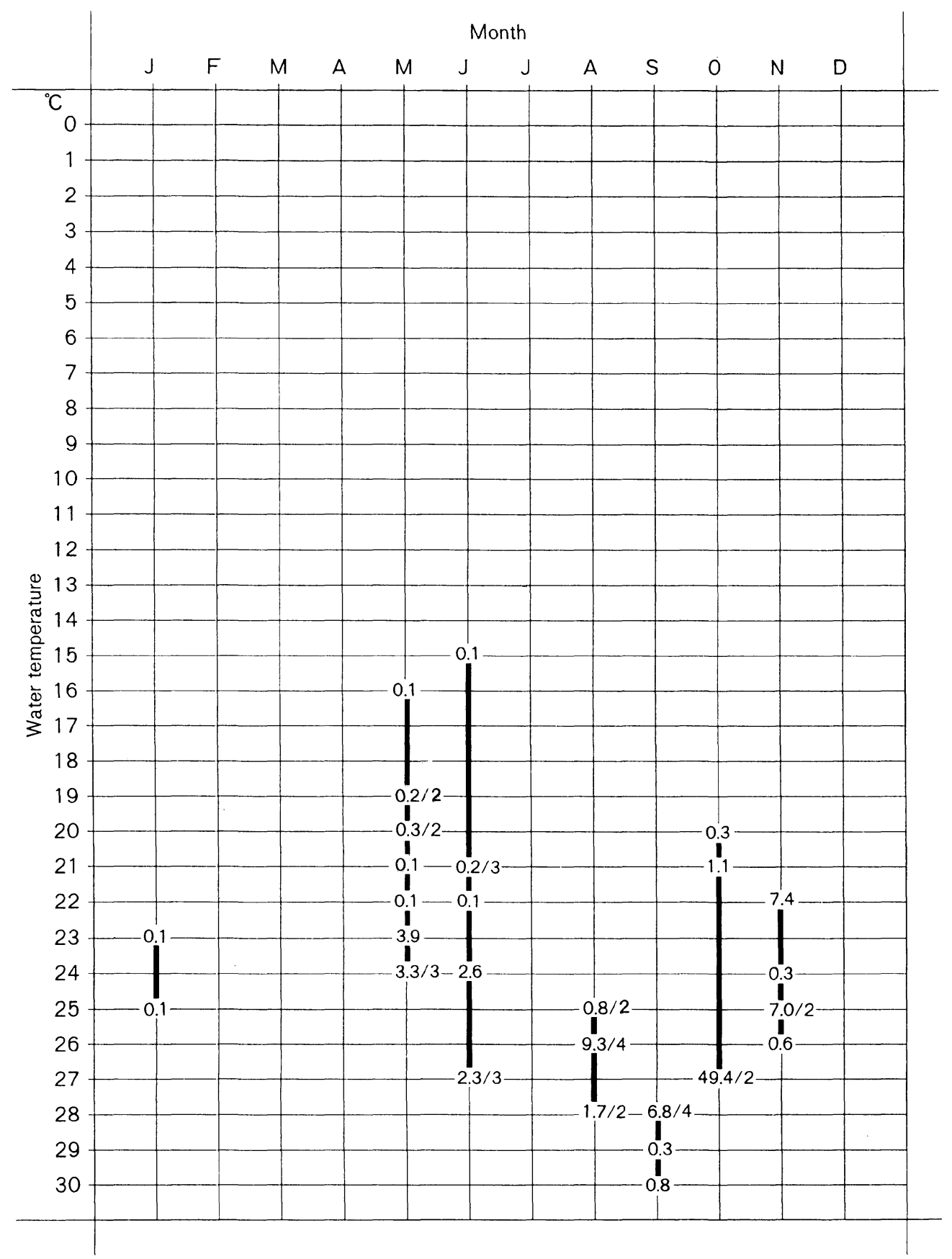

3) Puffinus pacificus

(2) Pterodroma arminjoniana, not tabled) 


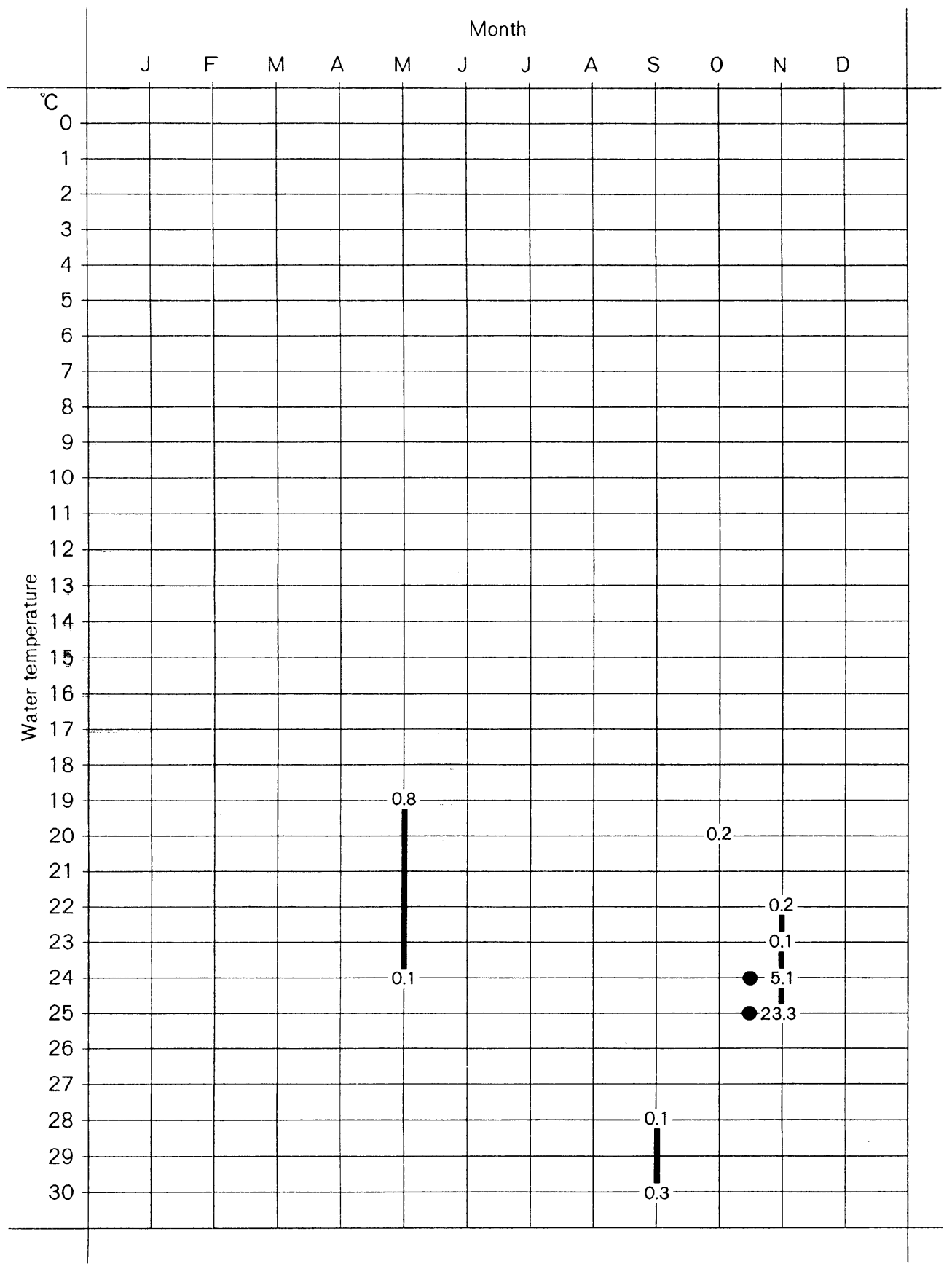

4) Puffinus nativitatis

5) Puffinus lherminieri 
b. Southern hemisphere migrants

b-1. Subtropical limitted

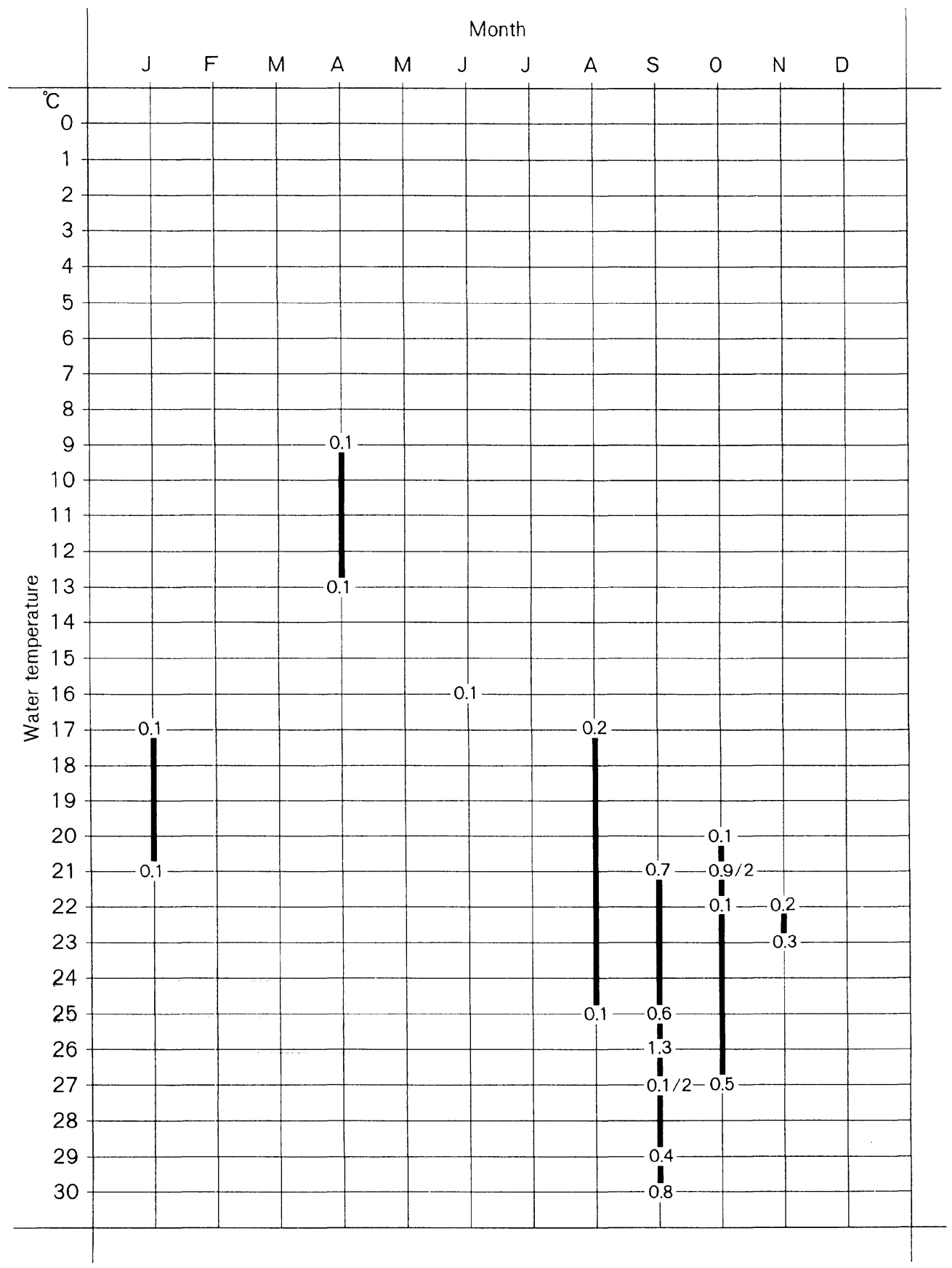

1) Pterodroma neglecta 
Procellariiformes in the North Pacific

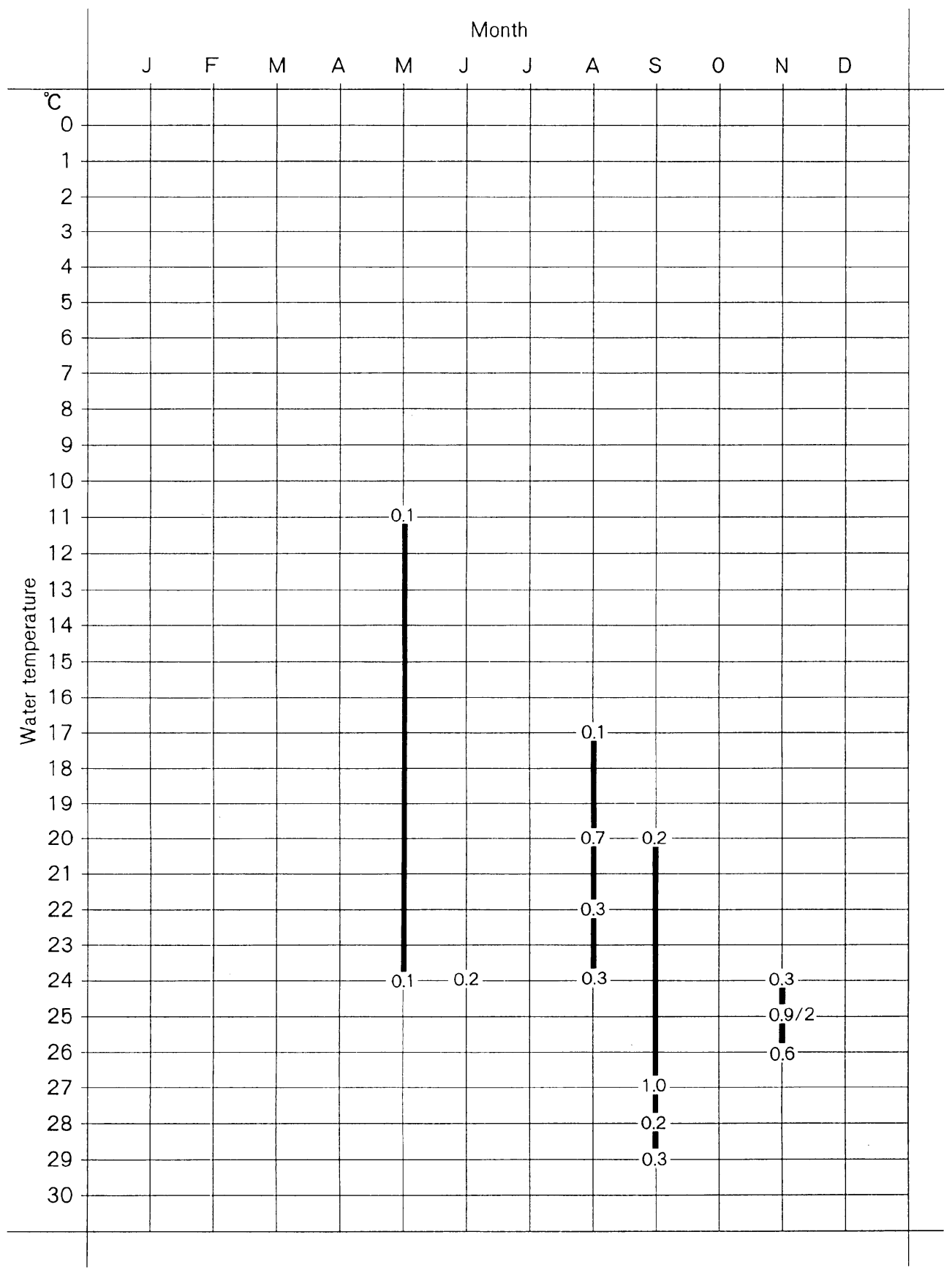

2) Pterodroma externa externa 


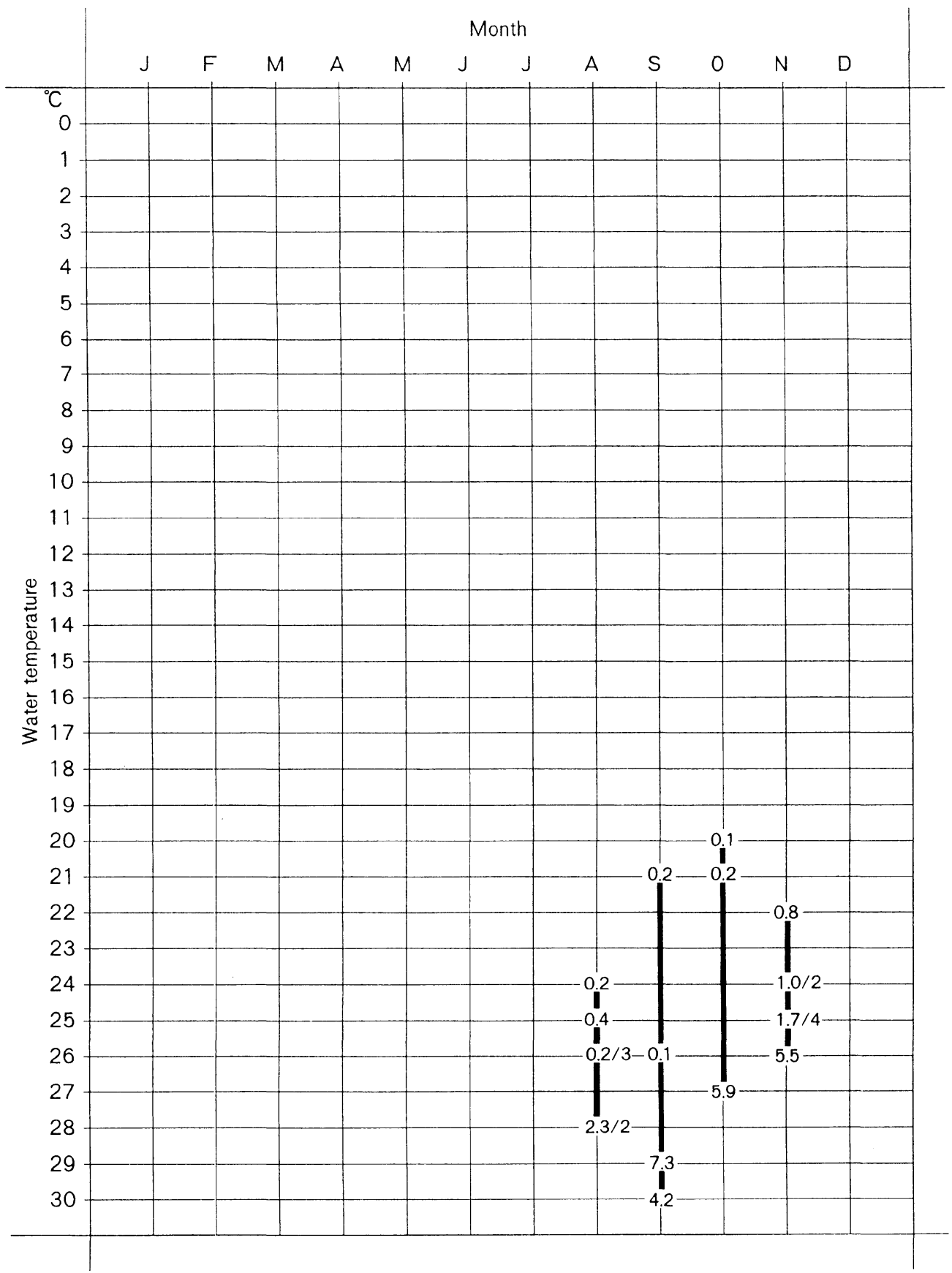

3) Ptrodroma externa cervicalis 


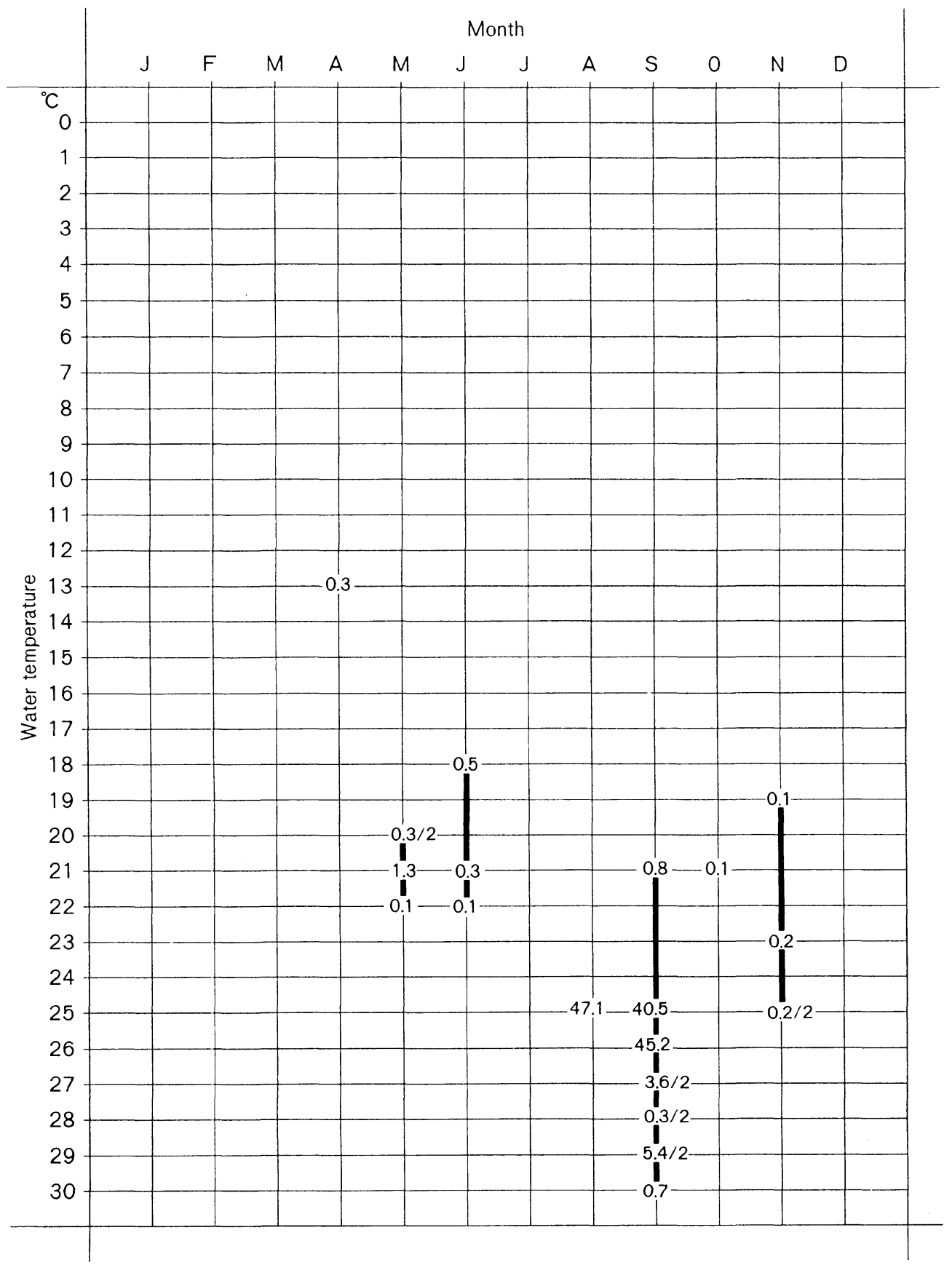

4) Pterodroma longirostris 


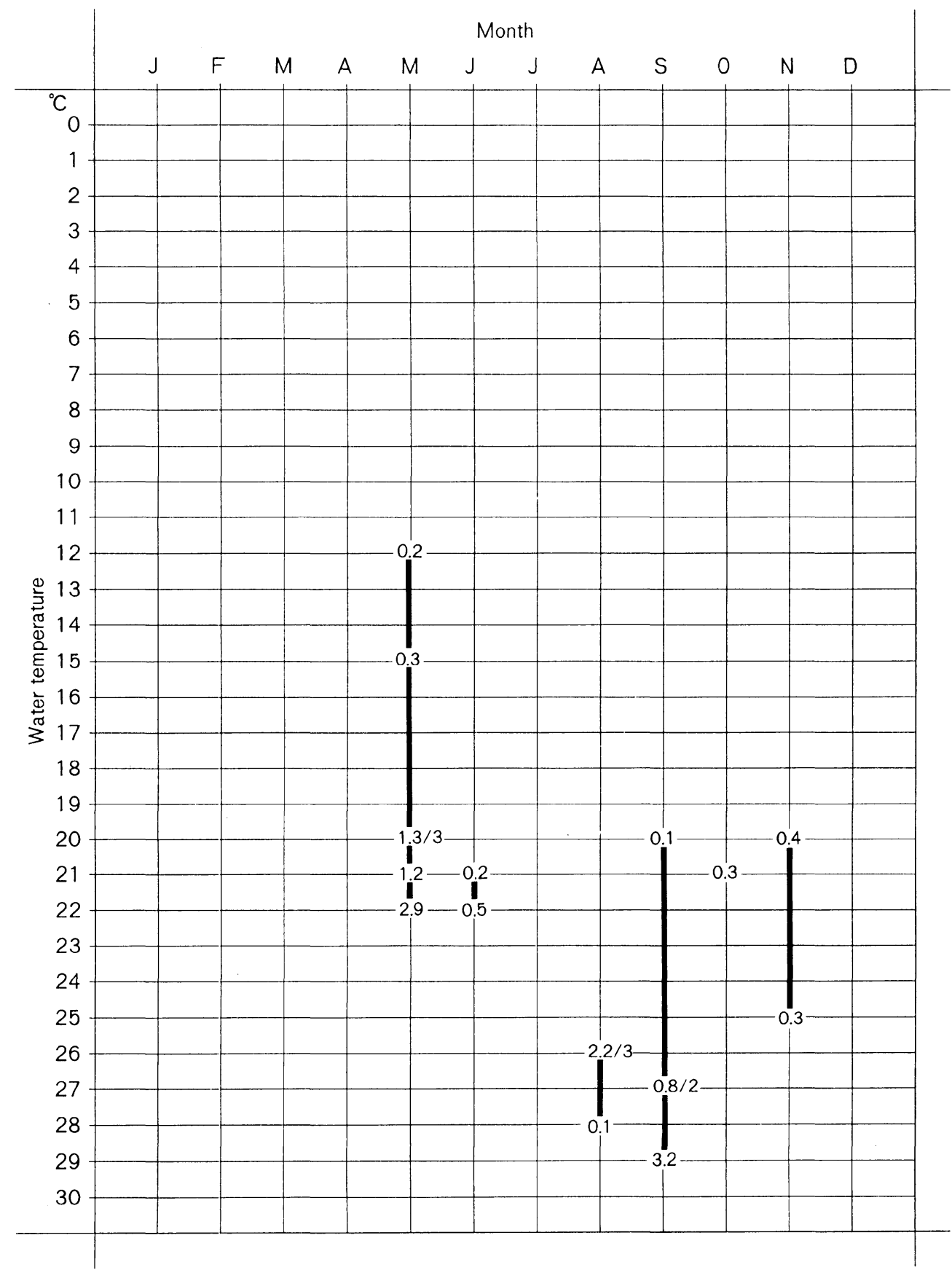

5) Pterodroma nigripennis 


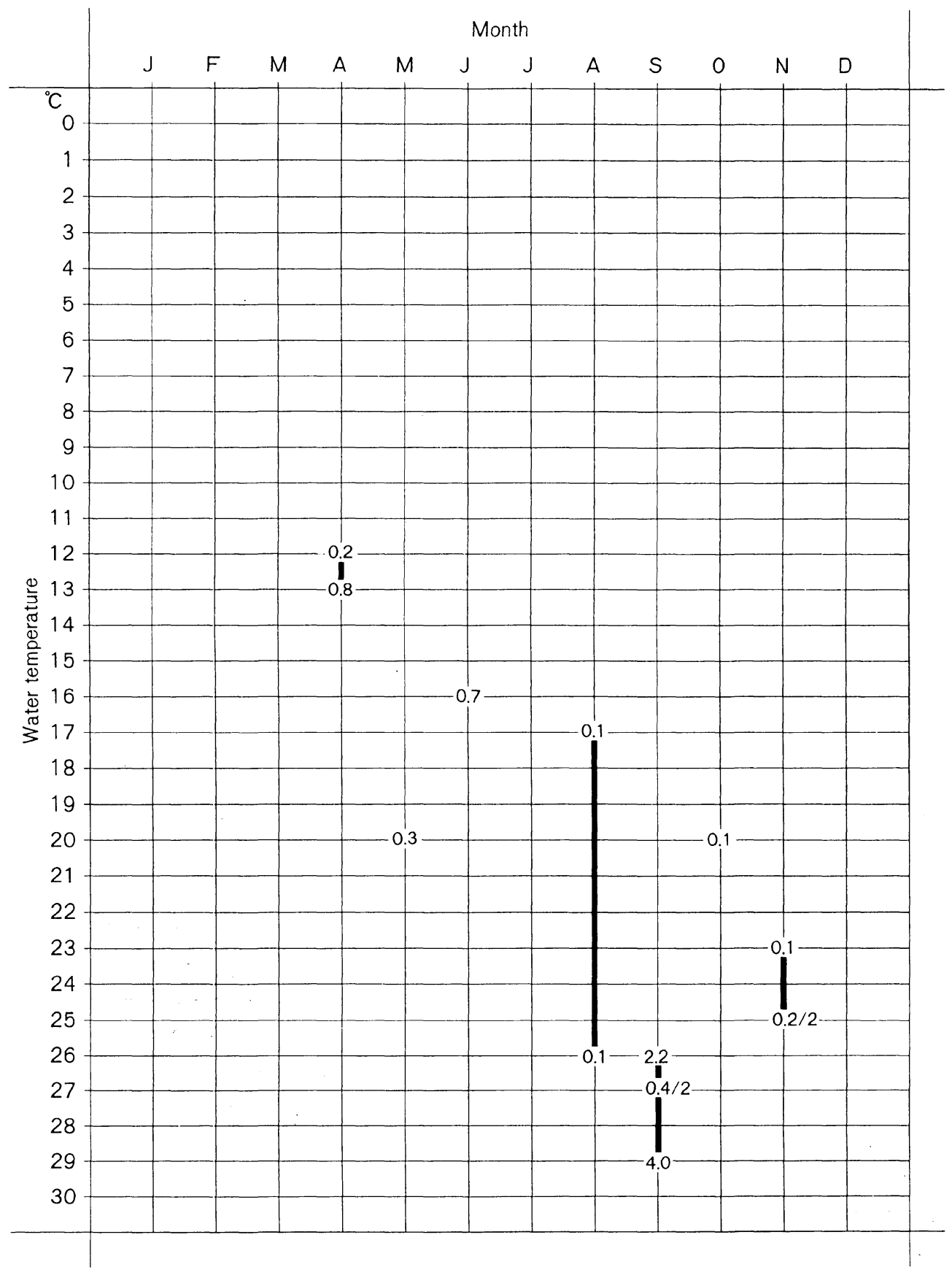

6) Pterodroma cookii 
N. Kuroda

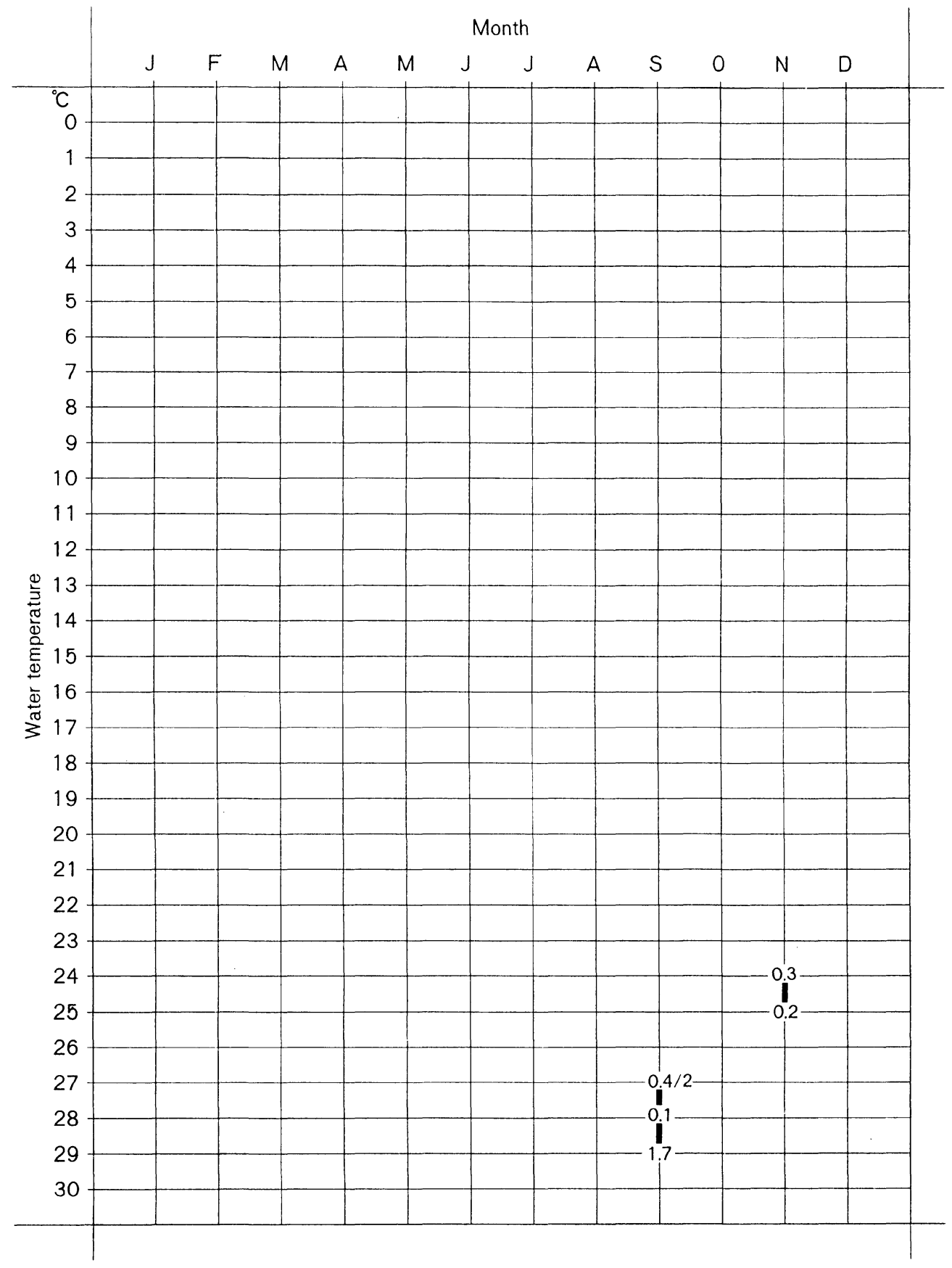

7) Pterodroma pycrofti 
b-2. North to temperate zone

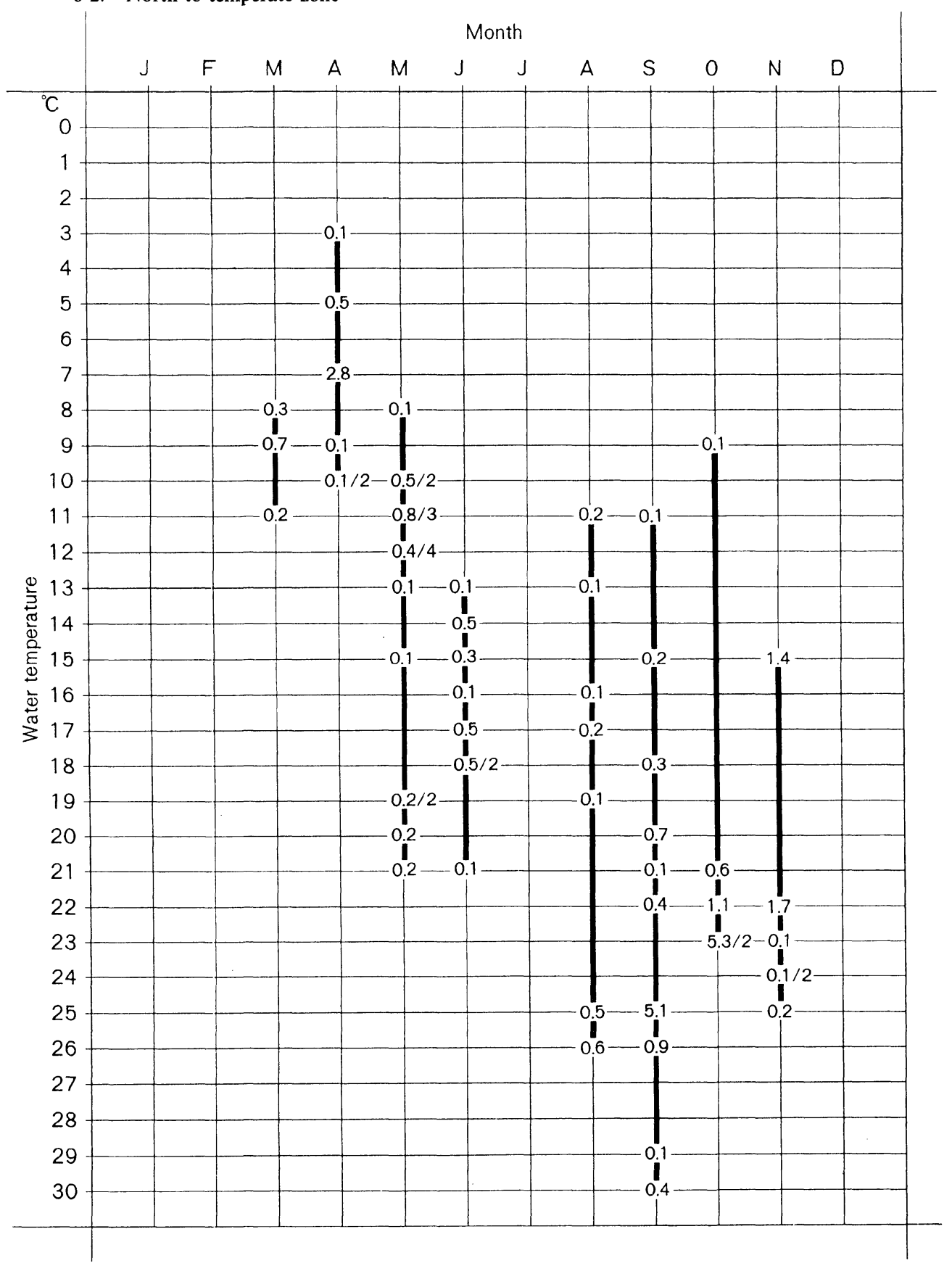

1) Pterodroma solandri 


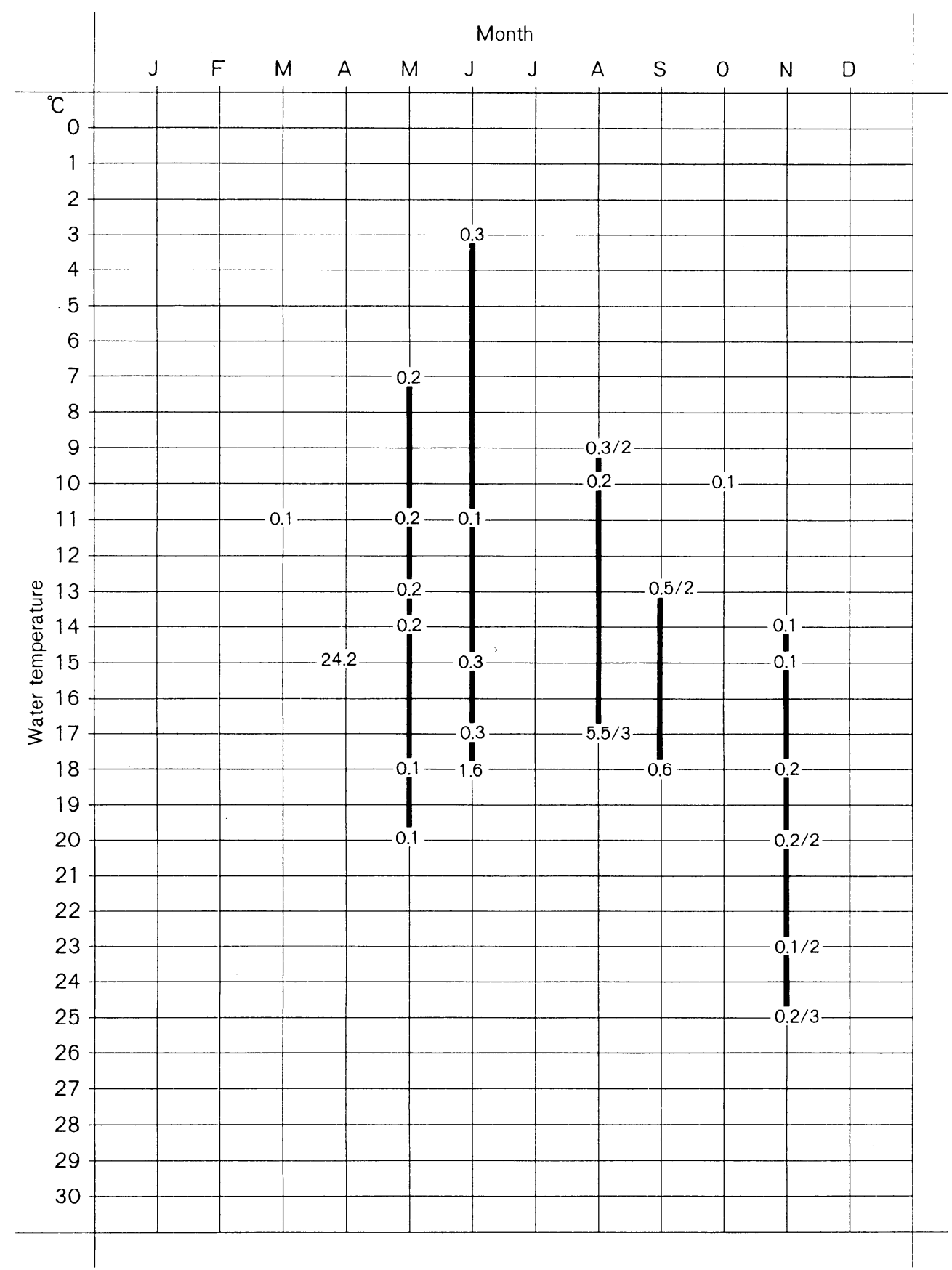

2) Puffinus carneipes 


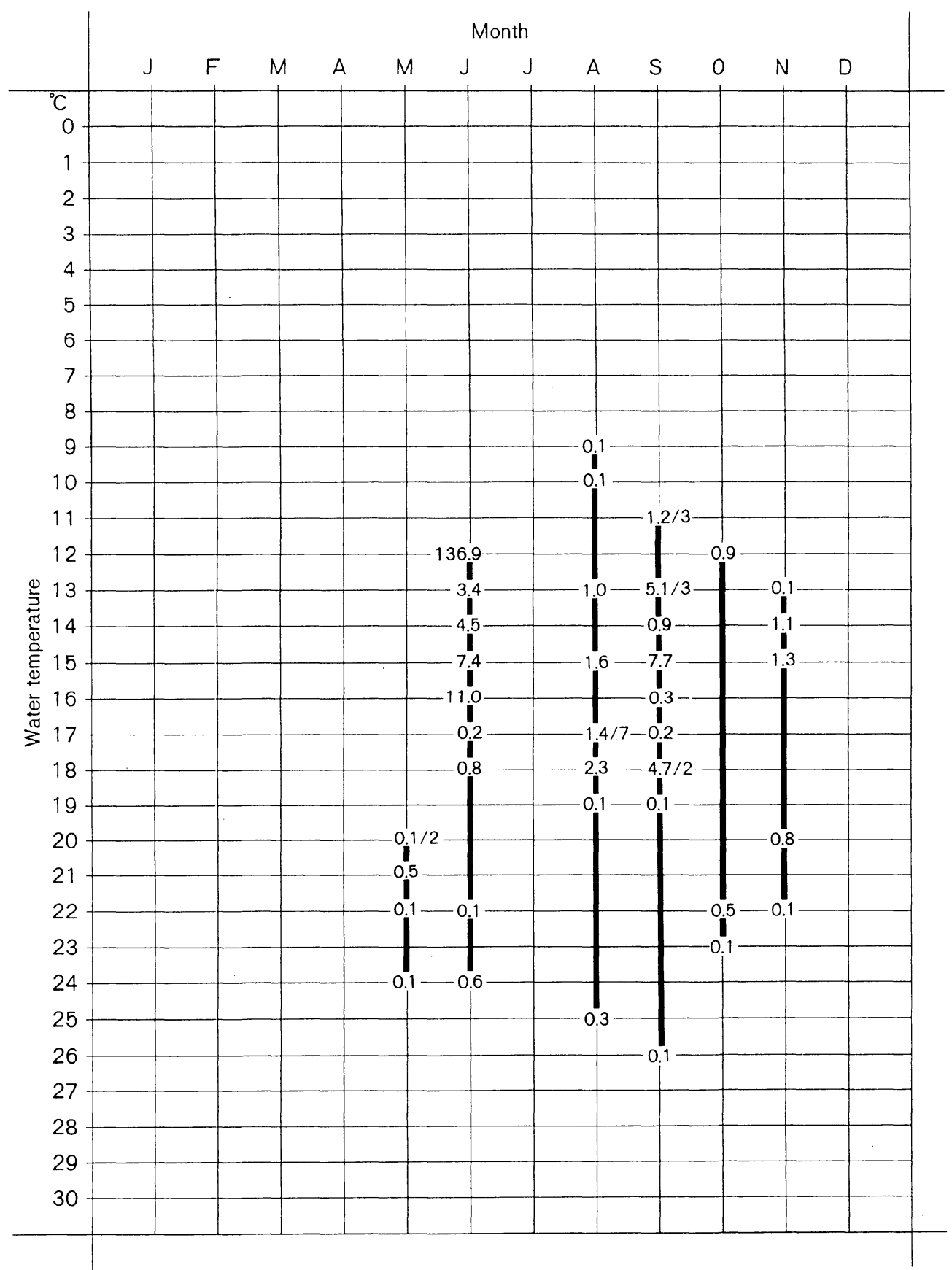

3) Puffinus bulleri 


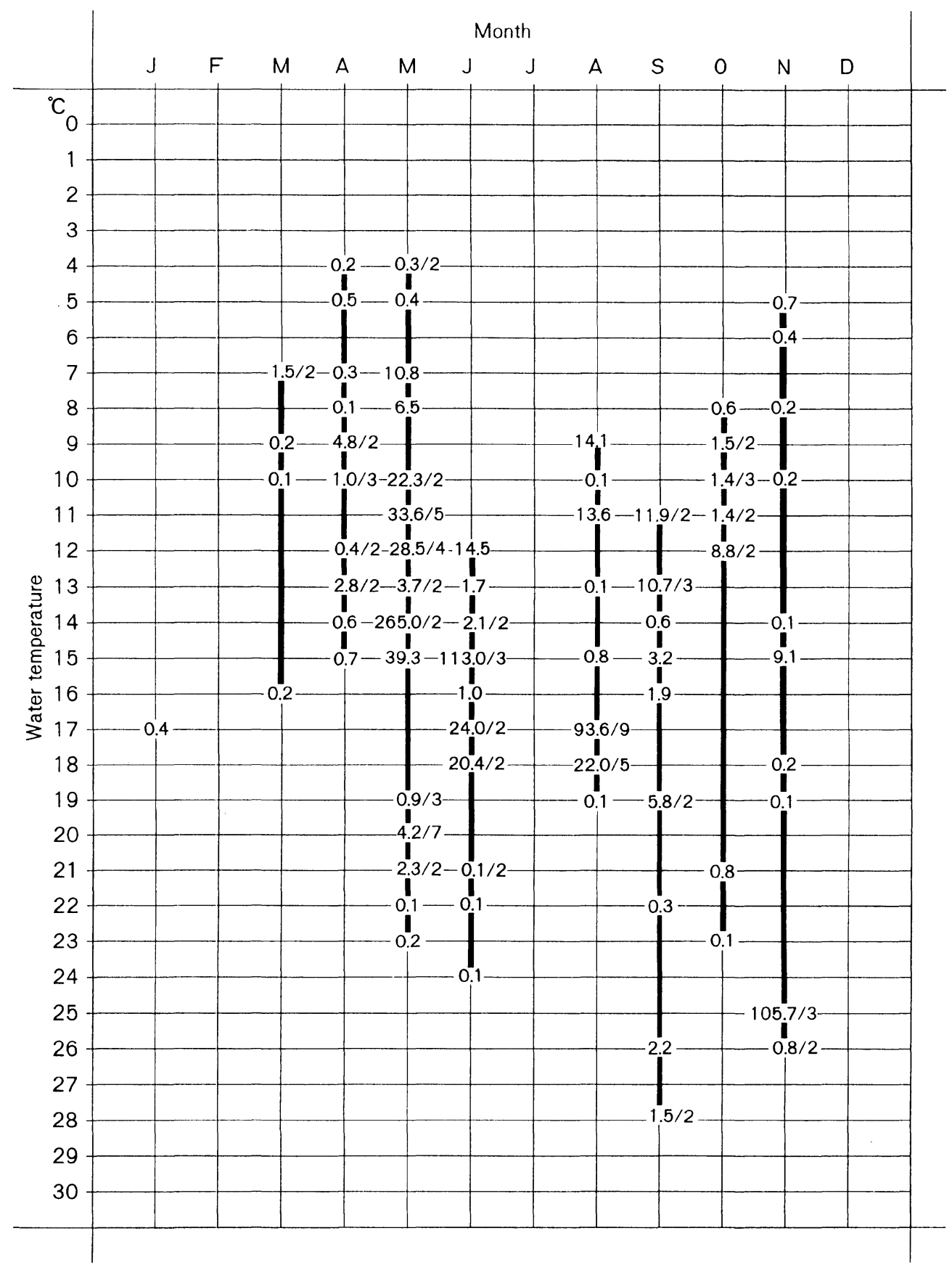

4) Puffinus griseus 
b-3. North into Bering Sea

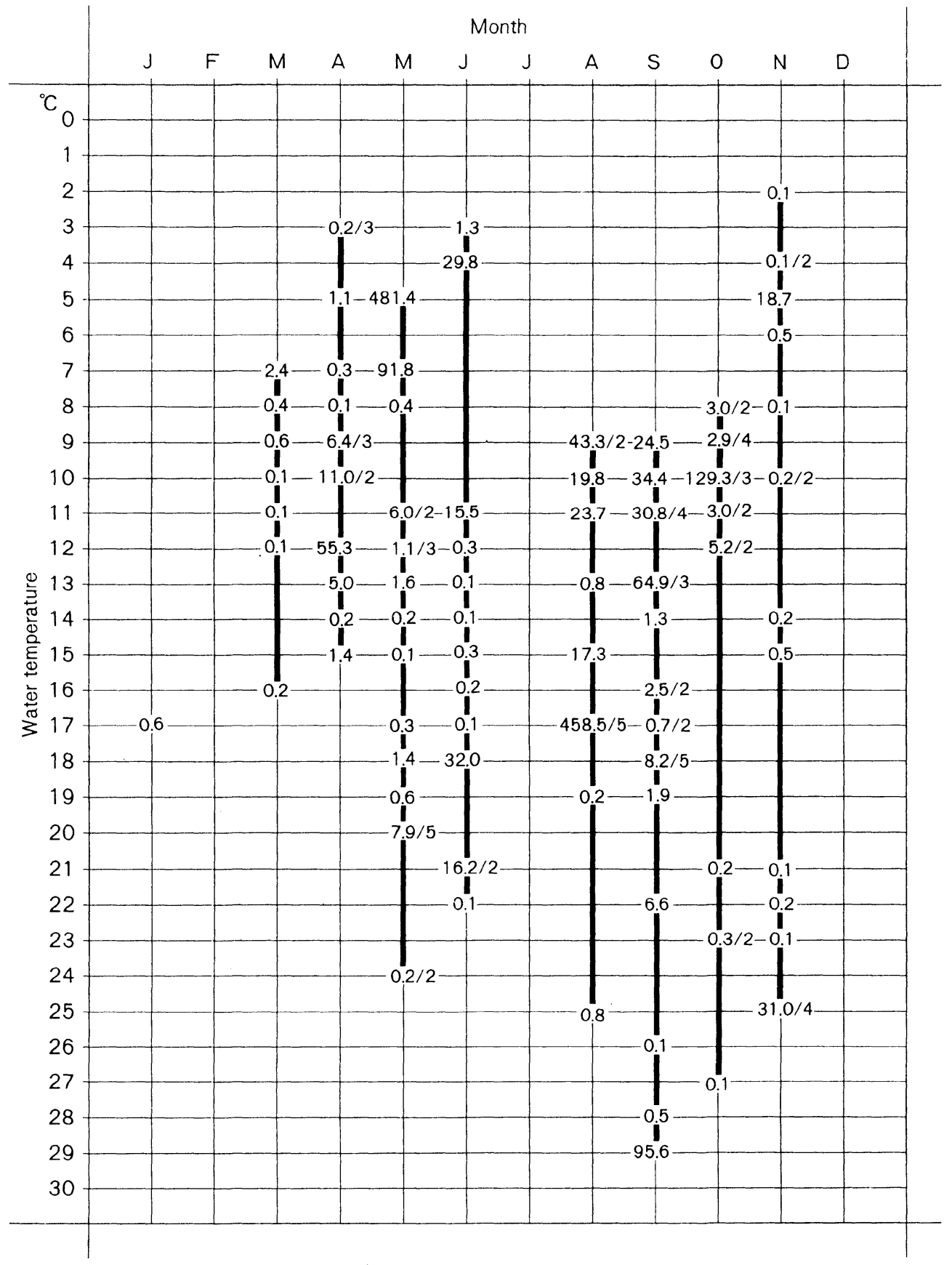

1) Puffinus tenuirostris 


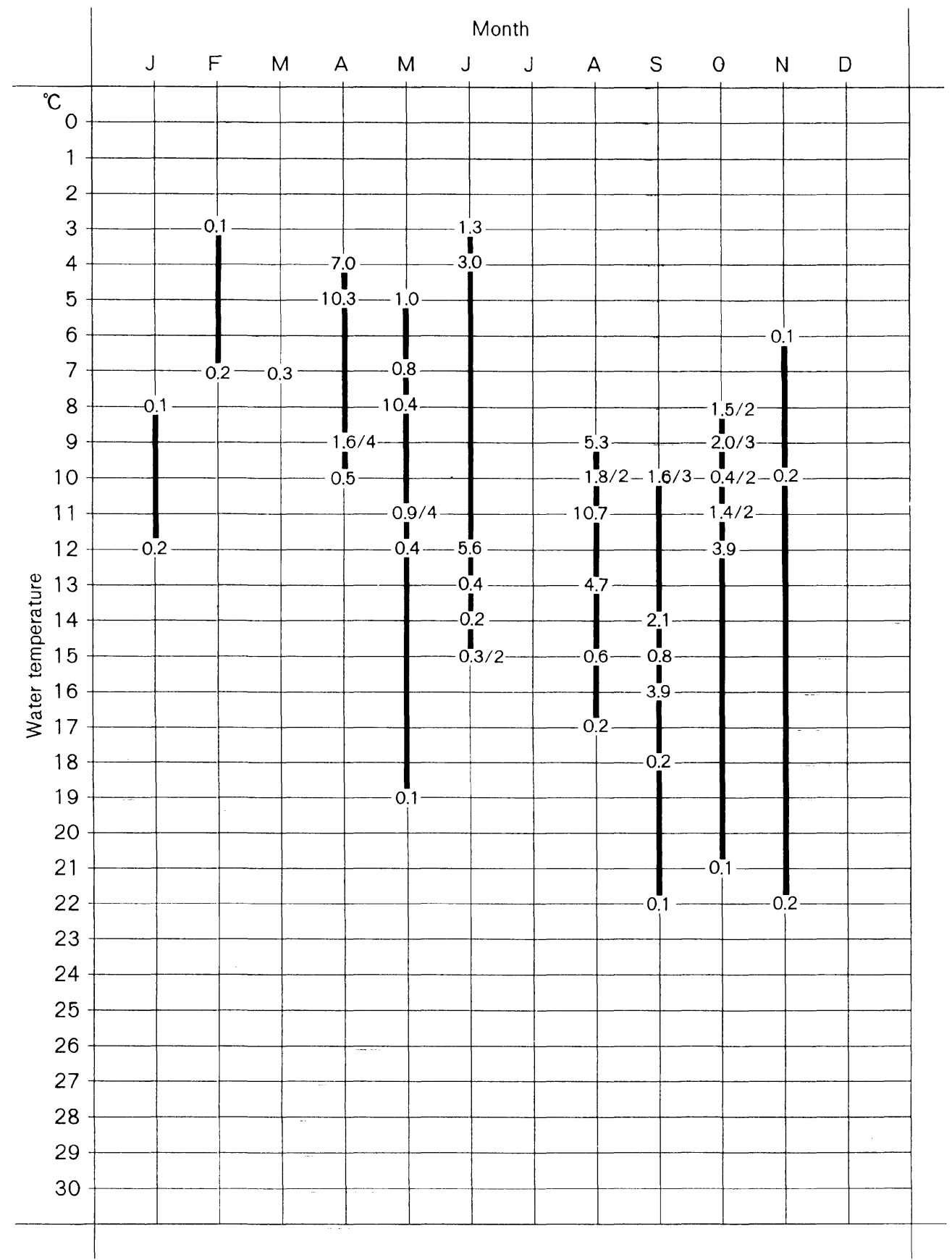

2) Pterodroma inexpectata 